UNIVERSIDADE DE SÃO PAULO

FCF/FEA/FSP

Programa de Pós-Graduação Interunidades

em Nutrição Humana Aplicada - PRONUT

\title{
"QUALIDADE DE VIDA NO TRABALHO: COMO A NUTRIÇÃO ESTÁ INSERIDA NOS PROGRAMAS DE QVT"
}

\section{ELIETE BERNAL ARELLANO}

Dissertação para obtenção do grau de Mestre

Orientador:

Prof. Dr. Antonio Carlos Coelho Campino Co-orientadora:

Prof $^{a} \mathrm{Dr}^{2}$ Ana Cristina Limongi França

\section{São Paulo}

2003 


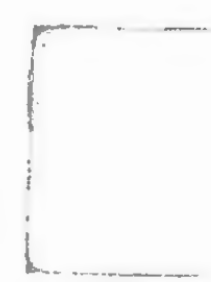

DEDALUS - Acervo - CQ

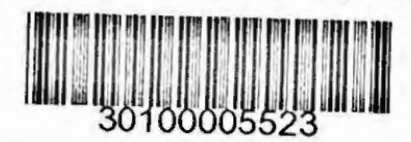

Autorizo, exclusivamente para fins acadêmicos e científicos, a reprodução total ou parcial desta dissertação, por processos fotocopiadores,

Assinatura:

Data: $19 / 08 / 2003$

Arellano, Eliete Bernal

Qualidade de vida no trabalho: como a nutrição está inserida nos programas de QVT / Eliete Bernal Arellano -- São Paulo : FEA/FSP/FCF/USP, 2003.

$147 \mathrm{p}$.

Dissertação - Mestrado

Bibliografia.

1. Qualidade de vida no trabalho 2. Capital humano - Teoria 3. Alimentaçăo 4. Nutrição I. Programa Interunidades FEA/FSP/ FCF da Universidade de São Paulo II. Título.

CDD - 306.361 
Eliete Bernal Arellano

“QUALIDADE DE VIDA NO TRABALHO: COMO A NUTRIÇÃO ESTÁ INSERIDA NOS PROGRAMAS DE QVT"

Comissão Julgadora

Tese para obtenção do grau de Mestre

\author{
Pro $^{a}$ Dr $^{a}$ Ana Cristina Limongi França \\ Presidente
}

Prof. Dr. Sigmar Malvezzi

$1^{\circ}$ Examinador

Prof $^{\mathrm{a}}$ Dr $^{\mathrm{a}}$ Sonia Tucunduva Philippi
$2^{\circ}$ Examinador

São Paulo, 19 de agosto de 2003 
“Näo pode haver maior, mais doce agrado, Que penetrar do mundo o espirito passado, $E$ de um sábio o conceito apreciar, presente, Vendo-o sempre avançar, no tempo, vivo e ardente!"

J.W. Goethe 
Aos meus pais, Carmen e Uriel, pelos valores ensinados, pelo afeto e apoio recebidos e pelo exemplo de dignidade.

Aos meus filhos, Mari e Dudu, por serem exatamente como såo e por me fazerem sentir o amor incondicional.

Ao meu marido, Eduardo, a pessoa que escolhi para compartilhar a minha vida. 


\section{AGRADECIMENTOS}

À Prof Dr̃ Silvia Maria F. Cozzolino, por seu incentivo à realização do curso e, principalmente, pela busca incansável pela excelência de todos, professores, alunos e colaboradores, evolvidos no PRONUT.

Ao meu orientador, Prof. Dr. Antonio Carlos Coelho Campino, pelo apoio, carinho e ensinamentos proporcionados nestes anos de estudo.

À Prof Dra Ana Cristina Limongi França, minha co-orientadora, pela amizade, clareza na orientação e inspiração de modelo profissional a ser seguido.

À CAPES, pelo suporte financeiro, fundamental para a realização deste trabalho.

A minha amiga Dóris Tristan Vicente, pela ajuda na confecção e estética visual do conteúdo deste trabalho.

À minha cunhada Pat Adams, pela revisão do Abstract

Ao Jorge, Elaine e Bel, equipe da secretaria do PRONUT, pela disposição constante em orientar e auxiliar no cumprimento das obrigações do curso.

Á Associação Brasileira de Qualidade de Vida no Trabalho - ABQV, na pessoa da Cecília Cibella Shibuya, por facilitar o acesso às empresas ganhadoras do prêmio anual.

A todos os professores que compartilharam os seus conhecimentos e auxiliaram no meu crescimento pessoal. 


\section{SUMÁRIO}

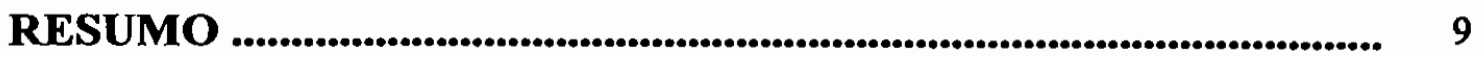

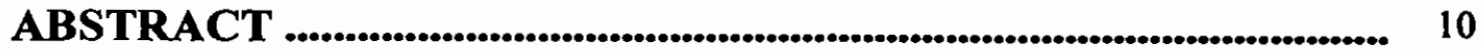

INTRODUÇÃO

\section{PARTE 1 - FUNDAMENTAÇÃO CONCEITUAL}

$1.1 \quad$ QUALIDADE DE VIDA NO TRABALHO ..................... 14

1.1.1 Evolução histórica ............................................................ 14

1.1.2 O que é qualidade de vida no trabalho ............................... 16

1.1.3 Os modelos de qualidade de vida no trabalho ..................... 22

1.1.4 Gestão de qualidade de vida no trabalho ............................ 30

$1.2 \quad$ COMPROMETIMENTO ................................................ 33

1.2.1 O que é comprometimento .............................................. 34

1.2.2 Comprometimento organizacional ..................................... 36

1.2.3 Instrumentos para avaliar o comprometimento organizacional ..................................................................... 39

1.2.4 Como conquistar o comprometimento dos empregados ...... 42

1.2.5 Considerações sobre comprometimento ................................ 45

1.3 A PESQUISA DE DADOS SECUNDÁRIOS ...................... 47

1.3.1 A pesquisa RH-2010 .......................................................... 47

1.3.2 A pesquisa focando o futuro $\mathrm{RH}$ no século 21 ..................... 51

$1.4 \quad$ A ALIMENTAÇÃO E NUTRIÇÃO ................................... 54

1.4.1 Importância dos nutrientes para a saúde e diminuição do risco de doenças ................................................................ 57

1.5 AS CONSEQUÊNCIAS DE UMA ALIMENTAÇÃO INADEQUADA …..................................................... 59

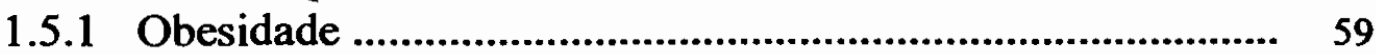

1.5.2 As doenças cardiovasculares ............................................... 64

1.5.3 Recomendações ............................................................... 66

1.6 TEORIA DO CAPITAL HUMANO 70

PARTE 2 - METODOLOGIA E ANÁLISE DOS RESULTADOS

$2.1 \quad$ OBJETIVO DA PESQUISA …....................................... 76

$2.2 \quad$ PROBLEMAS DA PESQUISA ….................................... 76 
$2.4 \quad$ METODOLOGIA DA PESQUISA ................................... 77

2.4.1 Plano Amostral .................................................................. 78

2.4.2 Elaboração do questionário e coleta de dados .................... 81

2.5.1 Caracterização das empresas pesquisadas ............................ 83

2.5.2 Os programas de qualidade de vida no trabalho .................. 86

2.5.3 A alimentação e nutrição dentro dos programas QVT........ $\quad 89$

2.5.4 As outras ações dos programas de QVT .............................. 92

2.5.5 Avaliação dos programas de QVT ...................................... 100

2.5.6 Mudança organizacional ................................................... 102

2.5.7 Índices de rotatividade e absenteísmo ................................ 103

\section{PARTE 3 - DISCUSSÃO E CONCLUSÕES}

$3.1 \quad$ DISCUSSÃO ............................................................... 106

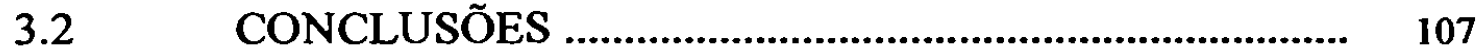

REFERÊNCIAS BIBLIOGRÁFICAS ............................................ 110

\section{LISTA DE FIGURAS}

Figura 1 Modelo completo das dimensões básicas da tarefa .......... 25

Figur'a 2 Áreas de visão de diferentes enfoques sobre QVT ......... 26

Figurarı 3 Pirâmide alimentar para portadores de doenças cardiovasculares

\section{LISTA DE GRÁFICOS}

Grífico $1 \quad$ Atividade da empresa ........................................................ 83

Grífico 2 Ano de criação da empresa ................................................. 83

Grífico $3 \quad$ Origem do capital ............................................................... 84

Grífico 4 Número de empregados das empresas pesquisadas ......... 85

Grífico 5 Número de empregados de RH das empresas pesquisadas ............................................................... 85

$\begin{array}{lll}\text { Grífico } 6 & \text { Padrões para o desenvolvimento do programa de QVT } & 87\end{array}$ Grífico $7 \quad$ Abrangência do programa de QVT .................................. $\quad 88$

Grífico 8 Empresas que contemplam alimentação e nutrição nos programas de QVT ......................................................... 90 
Gruífico 9 Ano de implantação da ação de alimentação dos programas de QVT

Grífico 10 Classificação das ações de QVT .................................... $\quad 93$

Grúfico II Avaliação dos programas de QVT junto aos

funcionários

Grífico 12 Empresas que informaram dados de rotatividade e absenteísmo

\section{LISTA DE TABELAS}

Tıbela / Critérios de Análise BPSO-96 de ações e programada de QVT .

Tabela 2 Indicadores do instrumento de Meyer, Allen e Smith.............................................................................. 40

Tabela 3 WCI - Workforce Commitment Index .............................. 41

Tabelı 4 RH 2010 - Políticas e gestão de pessoas ........................... 49

Tabela $5 \quad$ Workshop RH 2010 ........................................................... 50

Tabela $6 \quad$ Caracterização das empresas ............................................. $\quad 84$

Tabela 7 Número de empregados para cada profissional de RH .... $\quad 86$

Tabela 8 Ano de criação do programa de QVT e padrões para o desenvolvimento do programa ...................................... $\quad 87$

Tabela 9 Reporte hierárquico e abrangência do programa de QVT . 89

Tabela 10 Ações de QVT ............................................................. 93

Tabela II Resultados das ações de QVT ..................................... 99

Tahela 12 Visão dos funcionários e da diretoria dos programas de QVT ........................................................................ 101

Tabela $13 \quad$ Mudança organizacional ................................................... 102

Tabela 14 Índices de rotatividade e absenteísmo .......................... 103

\section{LISTA DE ANEXOS}

Auexo 1 A importância da alimentação na saúde ........................... 120

Anevo 2 Carta-convite ............................................................... 143

Anexo 3 Questionário de levantamento de dados ........................ 145 


\section{RESUMO}

Arellano. E.B. Qualidade de vida no trabalho: como a nutrição estí inserida nos programas de QVT; 2003 [Dissertação de Mestrado - FCF-FEA-FSP/USP].

Esta dissertação analisa os programas de qualidade de vida no trabalho que receberam o prêmio anual concedido pela $\mathrm{ABQV}$ - Associação Brasileira de Qualidade de Vida no Trabalho, no período de 1996 a 2001 . O método utilizado foi o de uma pesquisa exploratória, com dados coletados em 10 empresas de todo o Brasil. Tem-se como objetivo discutir as ações dos programas de Qualidade de Vida no Trabalho, os instrumentos de avaliaçð̃es utilizados e a apuração do impacto causado na produtividade, com especial atenção naquelas relacionadas com a alimentação e nutrição dos empregados das organizações. Os resultados obtidos demonstram que, a maioria das empresas pesquisadas está desenvolvendo ações, dentro dos seus programas de QVT, de orientação dos hábitos alimentares de seus funcionários, promovendo a saúde na tentativa de diminuir a incidência de doenças relacionadas a uma dieta inadequada, especificamente as relacionadas à obesidade, como as doenças coronarianas. A percepção dos resultados dos programas de QVT, tanto por parte dos empregados, como do corpo diretivo é que houve uma melhoria do clima organizacional e da imagem da empresa interna e externamente, além da mudança de hábito e melhoria do bem-estar dos empregados. Quanto aos indicadores de avaliação, as informações obtidas não tiveram a representatividade necessária para se fazer um estudo conclusivo sobre o impacto do investimento no capital humano na produtividade dessas empresas. 


\begin{abstract}
Arellano, E.B. Qualidade de vida no trabalho: como a nutrição está inserida nos programas de QVT; [ Quality of Life at Work: how nutrition is inserted on QLW programs]. São Paulo (BR); 2003 [Thesis of Master Degree - FCF-FEA-FSP/USP].
\end{abstract}

This work analizes the Quality of Work Life program that received the annual prize given by ABQV Associação Brasileira de Qualidade de Vida no Trabalho (Brazililan National Society of Quality of Work Life), during the period of 1996 to 2001. The method used was an exploratory quality survey, and the data was collected with ten companies around Brazil. The objective of this study is to discuss quality of work life actions, evaluation tools, and finding their impact on productivity, especially those related to employee's nutrition. The results show that most of the surveyed companies are developing actions, inserted into quality of work life programs, to adjust their employee's nutrition habits, therefore promoting health and giving the result of decreasing sicknesses related to inappropriate nutrition, like obesity and coronary diseases. With these results, the employees or board of director's perception of the quality work life programs reveals an improvement of organizational climate and company image, in addition to a change of habits and employees ${ }^{1}$ health-fare. Regarding evaluation tools, the data was not representative enough to conclude that the human capital resources invested had a positive impact on the company's productivity. 


\section{INTRODUÇÃo}

O presente trabalho é decorrência de uma experiência profissional da autora. Prestando serviços de consultoria para uma organização, verificou-se que após serem implantadas várias práticas de recursos humanos, como recrutamento e seleção, remuneração, treinamento, avaliação de desempenho, gestão participativa e excelência empresarial, ainda assim observava-se que a produtividade estava sofrendo interferência de vários fatores relacionados, principalmente, com a saúde fisica e o equilibro emocional dos empregados. Iniciou-se então, as ações de um Programa de Qualidade de Vida no Trabalho que acabou recebendo o Prêmio Nacional de Qualidade de Vida no Trabalho, no ano de 1998, promovido pela Associação Brasileira de Qualidade de Vida no Trabalho. Surgiu, assim, a necessidade de aprofundamento do tema.

Na revisão de bibliografia aborda-se a evolução histórica da Qualidade de Vida, os vários modelos conceituais, e por fim, uma defínição do tema. Na segunda parte, a discussão concentra-se no tema da alimentação, fazendo uma análise da nutrição e do desenvolvimento econômico e dos problemas decorrentes do desequilíbrio na alimentação, seja por carências nutricionais ou por excesso de ingestão de açúcar e gordura. Por último, a Teoria do Capital Humano é apresentada, fundamentando o investimento nos recursos humanos como um dos ingredientes mais decisivos na receita do crescimento econômico.

Na última parte do trabalho, serão apresentados os resultados do estudo que teve como objetivo discutir as açð̃es dos programas de Qualidade de Vida no Trabalho, 
os instrumentos de avaliações utilizados e a apuração do impacto causado na produtividade, com especial atenção naquelas relacionadas com a alimentação e nutrição dos empregados das organizações, através de uma pesquisa exploratória que teve como amostra as empresas ganhadoras do Prêmio Nacional de Qualidade de Vida no Trabalho, no período de 1996 a 2001. 
Parte 1

Fundamentação Conceitual 


\section{1 - QUALIDADE DE VIDA NO TRABALHO}

\subsubsection{Evolucão Histórica:}

O conceito de Qualidade de Vida no Trabalho tem sido avaliado e questionado através dos anos, firmando-se não como um modismo passageiro, mas um instrumento que auxilia o desenvolvimento humano e organizacional.

Goulard e Sampaio (1999) afirmam que a origem e evolução do movimento de QVT, teve a Escola de Relações Humanas como sendo uma das primeiras a se preocupar com o tema, tendo como representantes Elton Mayo, que observou que a produtividade aumenta quando acontecem fenômenos de grupo; Maslow e Herzberg cujos estudos sob motivação humana apresentaram uma fundamentação teórica sobre o tema; e Kurt Lewin com estudos de Dinâmica de Grupo, mostrando que a convivência e a participação tendem a aumentar a rentabilidade no trabalho. Esses estudos tinham como preocupação os aspectos psicossociais do trabalho e QVT só apareceu na literatura na década de 50, do século passado na Inglaterra quando Eric Trist e seus colaboradores estudavam um modelo macro para tratar o trinômio Indivíduo - Trabalho - Organização.

Walton (1976), define QVT como algo além dos objetivos da legislação trabalhista, que apareceu no começo do século $\mathrm{XX}$, com a regulamentação do trabalho de menores, da jornada de trabalho e descanso semanal, das indenizações por acidentes de trabalho e outras que cobrem riscos no trabalho. Também é além dos objetivos do movimento sindical após a grande crise dos anos trinta, que se centraram na segurança e salubridade no trabalho, o tratamento dispensado ao trabalhador e o 
aumento de seus salários; É também mais amplo que o enfoque dos psicólogos, surgido na década de cinquenta, em que se considera que existe uma correlação positiva entre o estado de ânimo e a produtividade e afirma que é possível elevá-los mediante a melhoria das relaçð̃es humanas; Ultrapassa também as novidades da década de sessenta, como a igualdade de oportunidades e os inumeráveis esquemas de enriquecimento do trabalho. São todos esses movimentos reformistas, mais as necessidades e aspiraçð̃es humanas que têm aparecido recentemente, como o desejo de trabalhar para um empregador que possui sensibilidade social.

Nadler e Lawler (1983), em sua análise sobre as origens do movimento da Qualidade de Vida no Trabalho descreve a primeira fase da QVT, de 1969 a 1974, quando um grande número de pesquisadores, acadêmicos, líderes sindicais e representantes do governo começaram a se interessar na forma em que se poderia influenciar a qualidade das experiências vividas pelas pessoas durante as horas de trabalho, preocupados com os efeitos do emprego sobre a saúde e o bem-estar das pessoas, e pela satisfação no trabalho. Esta euforia e atividade inicial continuaram até a metade da década de 70 e depois experimentou uma baixa, já que nos Estados Unidos a atenção foi desviada para outros itens como a inflação e os custos da energia. A partir de 1979, surgiu um novo ciclo de interesse na QVT estimulado pela competição internacional. Algumas iniciativas com muita visão, como as da General Motors, começaram a ganhar o apreço do público, coincidindo com uma crescente preocupação nacional pela produtividade. Estas iniciativas produziram uma grande quantidade de projetos de QVT nos Estados Unidos, constituindo uma grande preocupação em meados dos anos 80 . 
Huse \& Cummings (1985), consideram que foi na década de 60 que o movimento em QVT ganhou impulso, graças à influência que a conscientizaçăo dos trabalhadores e o aumento de responsabilidades sociais exerceram sobre os cientistas e dirigentes organizacionais.

Segundo Aguiar (2000), os fatores intervenientes no aumento da produtividade estão presentes no estudo da organização do trabalho desde o início do século, mas só a partir da década de setenta, os indicadores referentes às necessidades e aspiraçð̃es humanas ganham maior relevância, diante do desafio de produtividade das organizaçð̃es, em busca de competitividade, incluindo-se agora na avaliação da produtividade a responsabilidade social da empresa. Este fato sugere mudança de postura das organizaçð̃es, orientada pela compreensão da qualidade de vida no trabalho como um aspecto tão importante quanto a modernização tecnológica.

\subsubsection{O que é Qualidade de Vida no Trabalho}

Max Frisch disse uma vez: Nós pedimos trabalhadores e vêm seres humanos. E a contratação de seres humanos implica em trazer para dentro da organização uma diversidade de necessidades, expectativas, estágios de desenvolvimento cultural e ético, valores e culturas diferentes. $O$ grande desafio é manter o equilíbrio entre esse universo individual e a instituição, melhorando a produtividade e promovendo a qualidade de vida dos envolvidos nesse processo.

Em primeiro lugar, é importante conceituar Qualidade de Vida. Ballesteros (1996), considera Qualidade de Vida como bem-estar no domínio social, saúde, no domínio da medicina e nível de satisfação no domínio psicológico. Para ele, uma vida com qualidade é determinada por uma relação de equilíbrio entre forças internas e 
externas. Resumindo, Qualidade de Vida diz respeito justamente à maneira pela qual o indivíduo interage (com sua individualidade e subjetividade) com o mundo externo, portanto à maneira como o sujeito influencia e é influenciado.

Goulard e Sampaio (op. Cit.) analisam a importância do trabalho como elemento de satisfação e busca do ego ideal, e concluem que, embora a Qualidade de Vida Global e a Qualidade de vida no Trabalho sejam distintas, elas se interinfluenciam e insatisfações no trabalho podem causar desajustes na vida familiar e nas relações sociais fora do trabalho, enquanto insatisfações fora do trabalho exercem papel desadaptador sobre o trabalho.

O conceito de Qualidade de Vida no Trabalho é discutido por vários autores e dentro do seu percurso histórico:

Nadler e Lawler (op. cit.), definem Qualidade de Vida no Trabalho de acordo com a evolução no tempo e das diferentes pessoas que o utilizam:

De 1959 a 1972, a QVT foi definida como uma Variável, pois era vista como uma reação do indivíduo para o trabalho, ou como as consequências das experiências laborais sobre as pessoas. Esta perspectiva tinha como característica o fato de que estava focada nas consequências do trabalho, como satisfação e saúde mental, com ênfase no impacto que teria sobre os indivíduos;

De 1969 a 1974, se iniciou um grande número de projetos, cujo principal objetivo era que os operários e a administração trabalhassem juntos para melhorar a QVT. Surgiu a definição de Enfoque, também centrada nas consequências sobre o indivíduo, mais do que sobre os resultados oganizacionais. 
* De 1972 a 1975, surgiu a definição de Método, pois a QVT era vista como um conjunto de métodos, enfoques ou técnicas para melhorar o ambiente de trabalho e fazê-lo mais produtivo e satisfatório.

* De 1975 a 1980, foi um período de baixa atividade para a QVT e surgiu a definição de QVT como Movimento. Era considerada mais que uma simples afirmação ideológica sobre a natureza do trabalho e da relaçăo trabalhadororganização. Os termos administração participativa e democracia industrial, foram invocados como ideais do movimento de QVT.

* De 1979 a 1980, a QVT é sinônimo de Todo, onde todos os esforços de desenvolvimento e efetividade organizacional são considerados como parte dela. É concebida como um conceito global e é percebida como uma panacéia contra a competição externa, contra problemas de qualidade, contra baixa taxas de produtividade e contra todo o demais.

* Na sexta definiçăo, a QVT equivale a Nada, pelo inevitável fracasso dos projetos de QVT e pela incapacidade de cumprir com as promessas feitas.

Finalmente, Nadler e Lawler (op. cit) definem a Qualidade de Vida no Trabalho como uma forma de pensar sobre as pessoas, o trabalho e as organizaçð̃es. Seus elementos distintivos são: (1) uma preocupação pelo impacto que tem o trabalho tanto sobre as pessoas como sobre a efetividade organizacional, e (2) a idéia de participação na tomada de decisð̃es e solução de problemas.

Albuquerque e França (1998), definem Qualidade de Vida no Trabalho como um conjunto de ações de uma empresa que envolve diagnóstico e implantação das melhorias e inovaçðes gerenciais, tecnológicas e estruturais dentro e fora do ambiente de trabalho, visando propiciar condiçðes plenas de desenvolvimento 
humano para e durante a realização do trabalho. Existem muitas interpretaçð̃es para a Qualidade de Vida no Trabalho: desde o foco médico da ausência de doenças da pessoa, até as exigências de recursos, objetos e procedimentos que atendam demandas coletivas em determinada situaçăo. Diversas ciências têm dado contribuições específicas, dentre elas, a Saúde, a Ecologia, a Ergonomia, a Psicologia, a Sociologia, a Economia, a Administração e a Engenharia.

Segundo Chiavenato (1999), o conceito de Qualidade de Vida no Trabalho envolve tanto os aspectos físicos e ambientais como os aspectos psicológicos do local de trabalho. A QVT assimila duas posições antagônicas: de um lado, a reivindicação dos empregados quanto ao bem-estar e satisfação no trabalho e, de outro, o interesse das organizações quanto aos seus efeitos potenciais sobre a produtividade e a qualidade.

Ainda segundo Chiavenato (1999), o conceito de QVT implica um profundo respeito pelas pessoas. Para alcançar níveis elevados de qualidade e produtividade, as organizaçð̃es precisam de pessoas motivadas, que participem ativamente nos trabalhos, que executam e que sejam adequadamente recompensadas pelas suas contribuições.

Para Walton (1973), a QVT deve ter como meta gerar uma organização mais humanizada, na qual o trabalho envolve, simultaneamente, relativo grau de responsabilidade e de autonomia a nível do cargo, recebimento de recursos de feedback sobre o desempenho, com tarefas adequadas, variedade, enriquecimento do trabalho e com ênfase no desenvolvimento pessoal do indivíduo.

Bergeron (1982), afirma que a QVT consiste na aplicação concreta de uma filosofia humanista pela introdução de métodos participativos, visando modificar um ou 
vários aspectos do meio ambiente de trabalho, a fim de criar uma nova situação mais favorável à satisfação dos empregados e à produtividade.

Werther \& Davis (1983), vêem a Qualidade de Vida no Trabalho relacionada a um programa de cargos e carreira, construído com eqüidade e bem conduzido na organização.

Huse e Cummings (op.cit.) consideram que a QVT constitui uma forma de pensamento envolvendo pessoas, trabalho e organização, na qual se destacam os seguintes aspectos:

- Preocupação com o bem-estar do trabalhador e com a eficácia organizacional.

- Participação do trabalhador nas decisões e problemas do trabalho.

Esta definição pode ser explicitada por quatro programas: participação do trabalhador, projeto de cargos, inovação do sistema de recompensa e melhoria no ambiente de trabalho.

Após vários estudos e pesquisas realizadas sobre o assunto, Fernandes (1996) conceitua QVT como uma gestão dinâmica e contingencial de fatores físicos, tecnológicos e sócio-psicológicos que afetam a cultura e renovam o clima organizacional, refletindo no bem-estar do trabalhador e na produtividade das empresas. A autora complementa, explicitando que a QVT deve ser considerada como uma gestão dinâmica porque as organizaçð̃es e as pessoas mudam constantemente; e é contingencial porque depende da realidade de cada empresa, no contexto em que está inserida. Além disso, pouco resolve atentar-se apenas para fatores físicos, pois aspectos sociológicos e psicológicos interferem igualmente na satisfação dos indivíduos em situação de trabalho; sem deixar de considerar os aspectos tecnológicos da organização do próprio trabalho que, em conjunto, afetam a 
cultura e interferem no clima organizacional com reflexos na produtividade e na satisfação dos empregados.

Segundo Bennett (1983), o termo Qualidade de Vida no Trabalho tem sido usado para descrever valores relacionados com a qualidade de experiências humanas no ambiente de trabalho. Em essência, é um estado da mente, um estado de consciência influenciada por um composto de fatores no trabalho - fatores que estão relacionados pelo trabalho em si, pelo ambiente de trabalho e pela personalidade do empregado. Como se pode observar, vários autores associam a produtividade com a Qualidade de Vida no Trabalho. Isso porque, a melhoria da produtividade não pode ser discutida sem o reconhecimento de que o conceito de produtividade vai além da idéia de uma boa produção ou ser eficiente. É também um conceito que encontra as suas raízes no dinamismo humano, porque tem uma indispensável conexão com a melhoria da natureza e qualidade de vida para cada indivíduo no trabalho. A melhoria da produtividade significa motivação, dignidade e grande participação no desenho e desempenho do trabalho na organização. Significa desenvolver indivíduos, cujas vidas podem ser produtivas em todo o sentido. A produtividade não é só um conceito. É uma medida compreensiva de quão bem a organização como um todo tem as tarefas cumpridas. Nenhum outro sistema de medidas revela tanto sobre a competitividade, viabilidade, energia e vitalidade humana e lucratividade real da organização. (Bennett, op.cit.).

Ainda segundo Bennett (op. Cit), as estratégias para melhoria da Qualidade de Vida no Trabalho contribuem para um indispensável subproduto da melhoria da produtividade. Esse conjunto de idéias e cursos de ação são centrados nas seguintes estratégias para a melhoria da QVT: 
- A idéia de um trabalho significativo

- A idéia de expectativas altas

- A idéia de compartilhar objetivos

- A idéia de comunicação em duas vias

- A idéia do crescimento de oportunidades

- A idéia da participação dos empregados

- A idéia de Socialização

- A idéia de recompensas equitativas

- A idéia de um ambiente eficiente

- A idéia de um gerenciamento efetivo.

É dentro dessas idéias, que os vários modelos de Qualidade de Vida no Trabalho, foram desenvolvidos pelos vários autores, como apresenta-se a seguir.

\subsubsection{Os modelos de Qualidade de Vida no Trabalho.}

Walton (1976), propõe um modelo conceitual para avaliar a QVT nas organizações com oito categorias:

1. Remuneração justa e suficiente - Se refere a uma relação apropriada do salário relacionado com outros trabalhos, do padrão de desempenho da comunidade e do padrão subjetivo do empregado. 
2. Segurança e salubridade no trabalho - Os trabalhadores não devem ser expostos a condições ambientais, jornada de trabalho e riscos que possam ameaçar a sua saúde.

3. Oportunidade de utilizar e desenvolver as habilidades humanas - $\mathrm{O}$ uso $\mathrm{e}$ desenvolvimento das capacidades humanas deve responder a certas condições, como Autonomia, Variedade de Habilidades, Informação e Perspectiva da Atividade, Significado da Tarefa e Planejamento da mesma.

4. Oportunidade de Progresso e Segurança no emprego - São manifestados no desenvolvimento pessoal, desenvolvimento na carreira, possibilidade de aplicação das novas habilidades, sensação de segurança no emprego e na remuneração.

5. Integração Social na Organização - Um clima favorável na relações pessoais é atingido com a ausência de preconceitos, democracia social, ascensão na carreira, companheirismo, união e comunicação aberta.

6. Leis e Normas Sociais - O grau de integração social na organização está relacionado com o direito à privacidade pessoal, à liberdade de expressão de idéias, tratamento eqüitativo e normas claras.

7. O Trabalho e a Vida Privada - As condições para crescimento na carreira não devem interferir no descanso e vida familiar do empregado. 
8. Significado social da atividade do empregado - A atuação social da organização tem importante significado para os empregados tanto na sua percepçao da empresa, quanto da sua auto-estima.

Paiva e Marques (1999) detalham sobre as abordagens de Hackman e Oldham e de Westley. A concepção de Hackman e Oldham considera que a QVT se apóia em características objetivas das tarefas realizadas no ambiente organizacional. Neste sentido, os autores propuseram o "Modelo das Dimensőes Básicas da Tarefa". Tal modelo pressupðe que as "Dimensð̃es da Tarefa" influenciam os "Estados Psicológicos Críticos" que, por sua vez, determinam os "Resultados Pessoais e de Trabalho". Porém, a "Necessidade Individual de Crescimento" exerce forças em toda essa cadeia de fatores determinantes de QVT.

Moraes e Kilimnik, in Paiva e Marques (op. cit.), apontam que as diferenças individuais em termos de traços de personalidade, o não atendimento das necessidades básicas via trabalho, a conseqüente luta por salários e segurança e a percepção da conexão entre desempenho e recompensas via trabalho, dentre outros fatores, fazem dessa abordagem uma das mais indicadas para diagnosticar QVT. 
Figura 1 - Modelo Completo das Dimensões Básicas da Tarefa

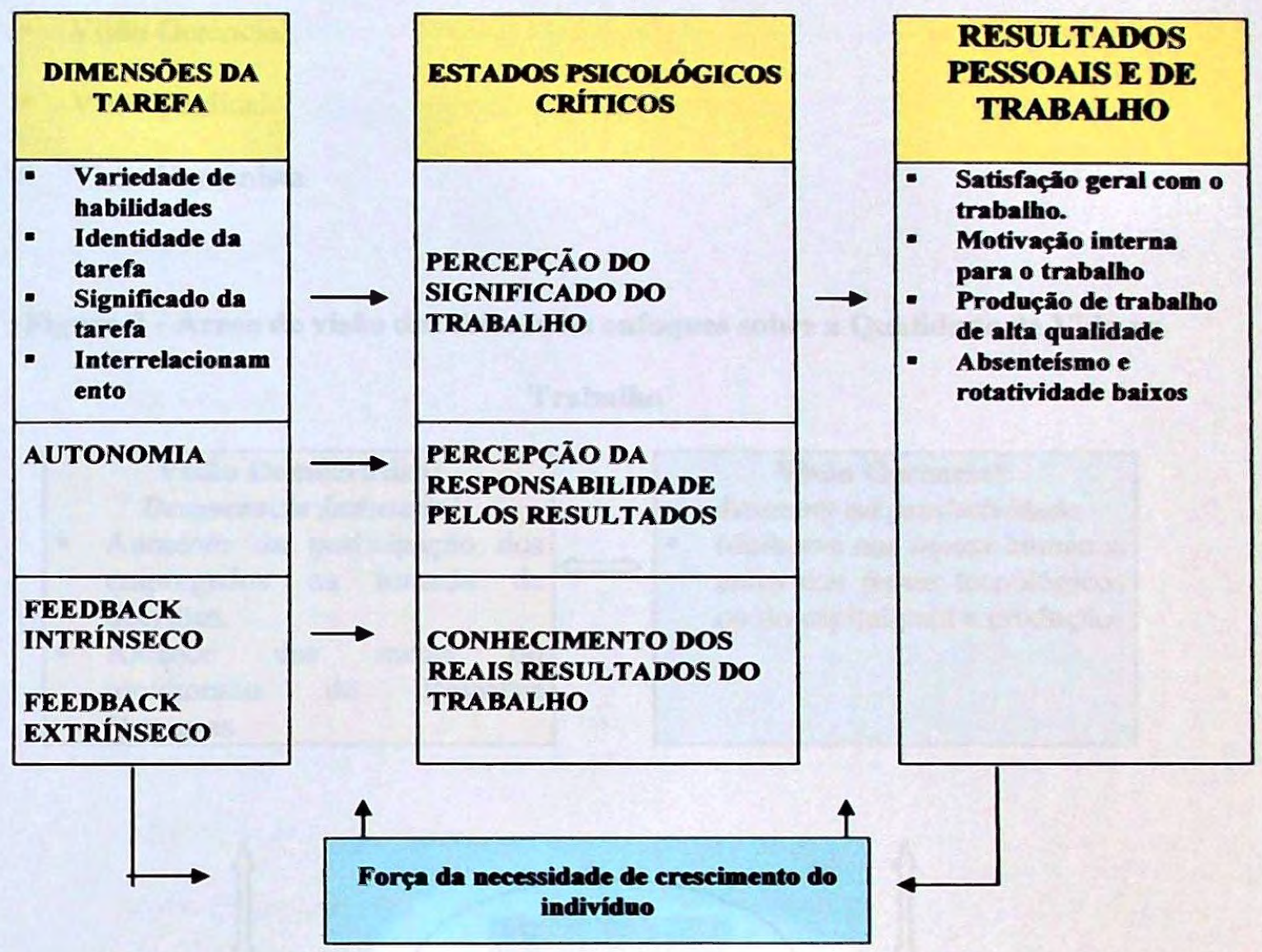

\section{Satisfaçōes Especificas}

Com as possibilidades de crescimento

Com a segurança no trabalho

Com a compensaç̃o

Com o ambiente social

Com a supervisão

Fonte: HACKMAN e OLDHAM (1975), adaptado por Moraes e Kilimnik et al. (1994), in Paiva e Marques (Op. Cit.)

Mendelewski e Orrego (1980), fazendo uma análise sobre os diversos enfoques da Qualidade de Vida no Trabalho, concluem que de acordo com a posição que as pessoas adotem frente ao tema, tendem a concentrar-se nas seguintes áreas de visão geral: 
- Visão Democrática

- Visão Gerencial

- Visão Sindical

- Visão Humanista

Figura 2 - Áreas de visão dos diferentes enfoques sobre a Qualidade de Vida no Trabalho

\begin{tabular}{|c|c|c|}
\hline 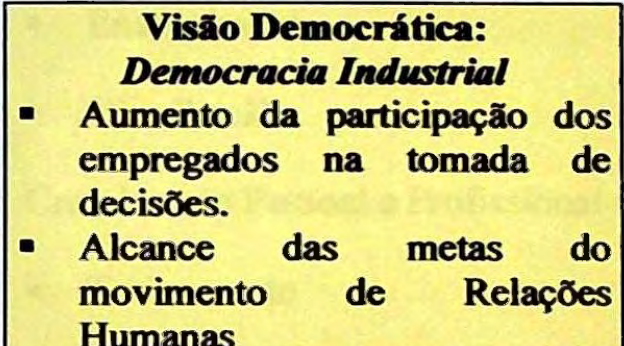 & $\Leftrightarrow$ & $\begin{array}{l}\text { Visão Gerencial: } \\
\text { Aumento na produtividade } \\
\text { Melhoras nos inputs humanos } \\
\text { antes dos inputs tecnológicos } \\
\text { ou do capital para a produção }\end{array}$ \\
\hline
\end{tabular}

$$
\{
$$

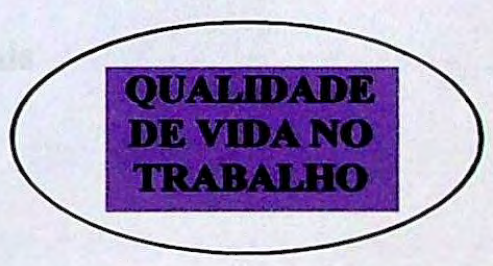

$$
\{
$$

\section{Visão Sindical: Conquistas Sociais}

- Alcance de porção mais equitativa das entradas e $\Longleftrightarrow$ recursos da organização produtiva.

- Alcance das condições de trabalho mais humanos e saudáveis

Fonte: Mendelewski e Orrego (Op. Cit.), adaptado de L. Suttle, La calidad de Vida de Trabajo en las

\section{Visto Humanista:}

Sativy ação de Necevridades

- Satisfação no cargo

- Humanização do Trabalho

- Organização personalizada

- Desenvolvimento Organizacional

\footnotetext{
Organizaciones Contemporáneas. Apunte DERTO, 1980.
} 
O modelo de Belanger (1973), in Fernandes (op.cit.), inclui aspectos ligados ao Trabalho em Si, Crescimento Pessoal e Profissional, Tarefas com Significado e, Funçð̃es e Estruturas Organizacionais Abertas. São eles:

1. O Trabalho em si:

- Criatividade

- Variabilidade

- Autonomia

- Envolvimento

- "Feedback"

2. Crescimento Pessoal e Profissional

- Treinamento

- Oportunidades de Crescimento

- Relacionamento no Trabalho

- Papéis Organizacionais

3. Tarefas com Significado

- Tarefas Completas

- Responsabilidade Aumentada

- Recompensas Financeiras/ não-financeiras

- Enriquecimento

4. Funções e Estruturas Abertas

- Clima de criatividade

- Transferência de Objetivos

Westley (1979), analisa quatro dimensões relacionadas ao trabalho e suas manifestações, tanto a nível individual, como social. Tais dimensð̃es são definidas como: o problema 
político, que traz como consequência a insegurança; o econômico, que traz a injustiça;o psicológico, que traz a alienaçăo e o sociológico, com a falta de normas socialmente construídas (anomia). $\mathrm{O}$ autor aponta duas maneiras de minimizar esses problemas: o enriquecimento do trabalho no âmbito individual e os métodos sociotécnicos para a reestruturação do trabalho do grupo, sugerindo que a participação de empregados, associaçð̃es de classe, sindicatos e partidos políticos são fundamentais para a manutenção do bem-estar intra-organizacional.

Por fim, salienta-se a importância da visão biopsicossocial estar presente dentro dos programas de QVT. Segundo França (1999), o ser humano reage sempre como um todo complexo, interligado em relações permanentes e fundamentais em nossa vida. São relações diferentes e interdependentes. São elas:

- A dimensão biológica, que se refere às características constitucionais herdadas e congênitas, incluindo os diferentes órgãos e sistemas que promovem o funcionamento do corpo humano. Inclui o metabolismo, as resistências e as vulnerabilidades do corpo.

- A dimensão psicológica, que corresponde aos processos afetivos, emocionais e intelectuais, conscientes ou inconscientes, caracterizando a personalidade, a vida mental, o afeto e o jeito de se relacionar com as pessoas e com o mundo que as rodeia.

- A dimensão social é relativa à incorporação e influências dos valores, das crenças e das expectativas das pessoas com as quais se convive, dos grupos sociais e das diferentes comunidades com as quais se entra em contato durante a vida, desde o nascimento. Inclui também a influência do ambiente físico e as características ergonômicas dos objetos utilizados.

Ainda segundo França (2001), a camada organizacional foi criada para atender às especificidades da cultura e do ambiente organizacionais, que se refere às questões de - 
imagem corporativa, inovação e tecnologia, sistemas de controle, movimentações registros, programas de treinamento e desenvolvimento e outras atividades específicas das empresas. A QVT envolve a dimensão organizacional, reconhecendo que grande parte das relações de trabalho, de suas práticas e seus valores nasce de experiências no chão da fábrica, dos processos de controle da produção, dos tempos e movimentos, evoluindo para a qualidade total e critérios de excelência. As principais contribuições da escola organizacional são:

- Expansão dos processos de qualidade e produtividade para o de qualidade pessoal.

- Política de gestão de pessoas - valorização e capacitação

- Marketing - imagem corporativa e comunicação interna

- Tempo livre - desenvolvimento cultural, hábitos de lazer e esporte

- Risco e desafio como fatores de motivação e comprometimento

Tabela 1 - Critérios de análise BPSO-96 - Açōes e Programas de QVT

\begin{tabular}{|c|c|c|c|}
\hline $\begin{array}{c}\text { Area de } \\
\text { Investiges=0 }\end{array}$ & Deserigüo & Agies e Programas & $\begin{array}{c}\text { CElulas } \\
\text { Ongenimcionais }\end{array}$ \\
\hline Biológica & $\begin{array}{l}\text { Promoção da saúde e da } \\
\text { segurança, controle dos } \\
\text { riscos ambientais e } \\
\text { atendimento às } \\
\text { necessidades físicas em } \\
\text { geral. }\end{array}$ & $\begin{array}{l}\text { Mapas e riscos SIPAT, } \\
\text { refeições, serviço médico } \\
\text { interno e contratado. } \\
\text { Melhorias ergonômicas, } \\
\text { PSMO, treinamentos } \\
\text { específicos. }\end{array}$ & $\begin{array}{l}\text { Segurança do trabalho e } \\
\text { medicina ocupacional, } \\
\text { ambulatório, nutrição, } \\
\text { relaçōes industriais e/ou } \\
\text { recursos humanos. }\end{array}$ \\
\hline Psicoldgica & $\begin{array}{l}\text { Promocalo da auto- } \\
\text { estima e do } \\
\text { desenvolvimento de } \\
\text { capacidades pessoais e } \\
\text { profissionais. }\end{array}$ & $\begin{array}{l}\text { Processos de seleção e } \\
\text { avaliacão de desempenho, } \\
\text { carreira, remuneracăo e } \\
\text { programas participativos. }\end{array}$ & $\begin{array}{l}\text { Recrutamento e seleção, } \\
\text { treinamento de pessoal, } \\
\text { cargos e salários, } \\
\text { relaços industriais e/ou } \\
\text { recursos humanos }\end{array}$ \\
\hline Social & $\begin{array}{l}\text { Oferta de beneficios } \\
\text { sociais obrigatórios e } \\
\text { espontineos e criacia de } \\
\text { oportunidades de lazer, } \\
\text { esportes e cultura. }\end{array}$ & $\begin{array}{l}\text { Direitos legais, atividades } \\
\text { associativas e esportivas, } \\
\text { eventos do turismo, laver e } \\
\text { cultura atendimento a } \\
\text { familia. }\end{array}$ & $\begin{array}{l}\text { Serviço social, grêmio } \\
\text { epportivo, fundapöes } \\
\text { eppecificas, recursos } \\
\text { humanos. }\end{array}$ \\
\hline Orzenincional & $\begin{array}{l}\text { Valoriescio da imagem } \\
\text { corporativa, da estrutura } \\
\text { organimacional, dos } \\
\text { produtos e servicos e do } \\
\text { relacionamento da } \\
\text { empresa com os } \\
\text { empregados. }\end{array}$ & $\begin{array}{l}\text { Endomarketing comites } \\
\text { executivos e de docisila, } \\
\text { comunicapio interma, } \\
\text { imagem exterma, } \\
\text { responsabilidade social e } \\
\text { cidadania. }\end{array}$ & $\begin{array}{l}\text { Diretorias executivas, } \\
\text { Marbeting, recursos } \\
\text { bumanos, fundacoles } \\
\text { eductocionais. }\end{array}$ \\
\hline
\end{tabular}

Fonte: Limongi, 2001 
A partir de todas as análises feitas até aqui sobre o tema, apresenta-se a seguinte proposta conceitual:

Qualidade de Vida no Trabalho tem como objetivo principal a busca do equilfbrio psíquico, fisico e social dos empregados, dentro do contexto organizacional considerando as pessoas como seres integrados nessas três dimensōes, através de ações que refletem em um aumento na produtividade e na melhoria da imagem da empresa tanto no contexto interno, como externamente, levando a um crescimento pessoal $e$ organizacional.

O grande desafio é fazer com que a organização contemple esta realidade, que veja o homem como um ser integral, para poder integrá-lo. Dos vários modelos de Qualidade de Vida no Trabalho aqui abordados, podemos perceber que todas as abordagens se complementam com o objetivo de cumprir esse papel.

\subsubsection{A gestão de qualidade de vida no trabalho}

França (2003), faz uma análise sobre as mudanças ocorridas no cenário atual influenciado pela globalização e sobre a busca de diferencial competitivo e desenvolvimento tecnológico que resultam em constantes alinhamentos das questões organizacionais e da dimensão humana que geram a necessidade de se construir uma 
nova forma de administrar o bem-estar: a gestão de qualidade de vida no trabalho. São citados os seguintes fatores críticos:

- Conceito de QVT, já abordado no item anterior.

- Produtividade: Também já discutida anteriormente, porém definida por França (2003, op. cit.), como o grau de aproveitamento dos meios utilizados para produzir bens e serviços, aproveitando ao máximo os recursos disponíveis para chegar a resultados cada vez mais competitivos.

- Legitimidade: No ambiente organizacional, Milkovich e Bourdreau in França, 2003 (op.cit), definem legitimidade como imparcialidade percebida pelos atores envolvidos sobre as decisð̃es adotadas, envolvendo a noção de que as decisð̃es, os comportamentos e as atitudes individuais ou específicas são aceitas e respeitadas.

- Perfil do gestor: definido como o Administrador que com a sua atuação viabiliza a gestão de QVT de maneira mais efetiva e consistente com as necessidades das pessoas e das empresas. De uma forma geral, o profissional deve ter valores como responsabilidade social, justiça e ética profissional, deve ter visão e sensibilidade para questð̃es do meio social, político, econômico e cultural, deve ter análise crítica e visão de futuro, promovendo transformaçð̃es e desenvolvimento contínuo. Apesar de ter-se definido o perfil do profissional em Administração na QVT, esse mesmo perfil pode ser extensivo a outros profissionais com formaçð̃es diferentes, como médicos, psicólogos e assistentes sociais que, na prática, têm atuado como gestores de programas de QVT com excelentes resultados.

- Práticas e Valores: As práticas e valores relacionados às questðes de QVT são numerosos e diversificados. Eles estão ligados às várias escolas de pensamento, como a Socioeconômica, a Organizacional e a da Condição Humana no Trabalho. 
- Nova Competência: A revisão dos valores quanto à natureza de resultados de capital e de benefícios sociais, além de resultados de desenvolvimento humano e de cidadania, levaram à construção de uma nova competência que tem como tripé conceitual três elementos: Conhecimento do Negócio, Técnicas para resolver as questões levantadas e Estratégia de negócio, que é o conjunto de procedimentos para atingir os objetivos alcançados. Essa nova competência tem focos em Âmbitos da organização, do conhecimento, dos sistemas de informação e da expansão do conceito de administração.

Esses fatores críticos abordados servem como parâmetro para análise das ações de qualidade de vida no trabalho, no ambiente organizacional. Na etapa final deste estudo, os resultados apurados na pesquisa exploratória serão avaliados à luz desses fatores. 


\section{2 - COMPROMETIMENTO}

As mudanças no ambiente empresarial dos últimos anos, com a globalização em uma esfera maior e com a abertura de mercado aqui no Brasil, levaram as organizações a rever suas estratégias e, dentre elas, conquistar o comprometimento dos empregados, como uma forma de adquirir um diferencial competitivo.

Diante deste cenário nota-se também a inserção de projetos diferenciados, dentre eles - Programa de Qualidade de Vida do Trabalhador com a preocupação das organizações em desenvolver ações que objetivem cuidar, proteger e viabilizar o bem-estar de seus colaboradores, a partir de demandas pessoais, organizacionais e riscos ocupacionais.

Giddens (2001) comenta que, de maneira geral, entende-se que a globalização é econômica e envolve conexões que abrangem o mundo. Mesmo que uma parte considerável do comércio permaneça regionalizada, nos mercados financeiros a economia é plenamente global.

O autor concebe a globalização como sendo não apenas uma interdependência econômica, mas também uma transformação do tempo e espaço em nossas vidas. Eventos distantes, quer econômicos ou não, afetam-nos mais direta e imediatamente que antes. Ela está mudando a vida do dia-a-dia, particularmente nos países desenvolvidos, ao mesmo tempo em que está criando novos sistemas e forças transnacionais.

E é nesse ponto que a globalização afeta a Qualidade de Vida no Trabalho. Hoje não se permite a transgressão às condições mínimas de dignidade no trabalho. Um exemplo disso é a campanha mundial para não se comprar produtos de países que 
utilizam mão-de-obra infantil ou escrava. Através de um fator econômico, está se mudando valores antes aceitáveis localmente.

O comprometimento não é um conceito novo. Como Levinson (1999) citou, Niccolo Machiavelli escreveu que a maior fortaleza de um príncipe é a afeição do seu povo. É a única verdade, é uma segurança duradoura para a nação ou negócio. Também citou o general chinês Sun Tzu, que definiu comprometimento como uma das cinco chaves para o sucesso. "A lei Moral leva o povo a estar em completa harmonia com seus reguladores, e então, os seguirão indiferentes a sua própria vida, intrépidos a qualquer perigo". Júlio César, de Shakespeare é "constante como uma estrela do norte", por que ganhou o comprometimento de seus seguidores colocando o bemestar deles em primeiro lugar.

A seguir, será apresentada uma revisão bibliográfica do conceito de comprometimento e comprometimento organizacional, bem como os estudos e pesquisas realizadas sobre o assunto.

\subsubsection{O que é comprometimento}

Segundo Mendes (1996), é um conjunto de comportamentos confiáveis, previsíveis e dedicados que separam o sucesso do fracasso. Ter um alto grau de compromisso leva a pessoa ao sucesso tanto profissional como pessoal. Não deve ser confundido com outros fatores que podem contribuir para o sucesso, como:

Determinação - A habilidade de tomar uma decisão é mais fácil que sustentar um comprometimento. Um exemplo é a taxa de divórcio nos Estados Unidos que é de cinquenta por cento. Casar é fácil... difícil é ficar casado com o parceiro até a morte. 
Ambição - O comprometimento significa dedicação e incorpora integridade pessoal, enquanto ambição pode significar passar sobre outras pessoas para chegar ao topo.

Obrigaçåo - Implica em que deve-se fazer algo, enquanto comprometimento significa ser auto-motivado, um conceito interno e externo do dever. Além disso, muitas pessoas não fazem o que deveriam, por que não estão comprometidas.

Garantia - O comprometimento implica em um esforço para alcançar uma meta ou preencher uma decisăo, mas não é uma garantia. O comprometimento ajudará a pessoa a manter-se no caminho para o sucesso, alinhada aos seus valores e necessidades pessoais.

Ainda de acordo com Mendes (op.cit.), o comprometimento é composto por quatro áreas:

Visāo - É a habilidade para visualizar o sucesso e antecipar os resultados positivos. Sem a visão, o comprometimento não pode levantar vôo. Ele dá um cenário da meta.

Insight - É a habilidade de se conhecer e aplicar esse conhecimento no seu comprometimento. Nosso comportamento passado é um excelente preditor do comportamento presente e futuro.

Aceitação - Dos requisitos para a mudança, pode nos preparar para situações inesperadas e ajudar no ajuste. Comprometer-se com novos comportamentos é a parte mais difícil. 
Integração - Consiste em combinar os valores com os pensamentos, palavras e ações. Esse é o verdadeiro teste de comprometimento.

Os quatro fatores para o comprometimento, segundo Mendes:

- Visão ... criar expectativas que são realistas, alcançáveis e com metas de curto e longo prazos.

- Insight ... usar experiências passadas como uma ferramenta de aprendizagem para esforcos futuros.

- Aceitação ... deixar de lado as coisas que não se consegue controlar e focar nas coisas possíveis de fazer

- Integração ... fazer o que se diz e viver o comprometimento.

De acordo com Bastos, Brandão e Pinho (1997), o comprometimento é caracterizado por sentimentos ou reações positivas, como lealdade em relação a algo, ao qual se associam intenções comportamentais específicas.

\subsubsection{Comprometimento Organizacional:}

Em estudos realizados por Dessler (1999), ele concluiu que "ter um membro que divide as metas e valores da organização pode garantir que o seu ato individual instintivamente beneficiará a organização". Comprometimento - tanto para a empresa como para o empregado - foi positivamente relacionado com a disposição para ajudar. Uma outra conclusão foi que o comprometimento organizacional estava associado com a habilidade dos empregados e da organização em se adaptarem a ocorrências imprevistas. 
Ainda segundo Dessler, empregados comprometidos tendem a ter melhores registros de atendimentos e maior domínio do trabalho que os menos comprometidos. Também tendem a trabalhar mais e com melhor desempenho. Em resumo, são mais valiosos para a organização.

De acordo com Igbaria e Guimarães (1993, in Ricco 1998), o comprometimento organizacional reflete uma avaliação da organização como um todo e é composto por três dimensões: uma forte crença e aceitação dos objetivos da organização, boa vontade para exercer esforços em beneficio dela e um forte desejo de manter-se membro da mesma.

Segundo Teet e Meyer (1993, p. 261-262), Meyer e Allen articularam três formas de comprometimento organizacional. Comprometimento afetivo, que denota uma identificação e um envolvimento do empregado com uma determinada organização. Comprometimento instrumental, que está associado a perda de valores com a saída do empregado da empresa. E comprometimento normativo, que denota boa vontade do empregado em permanecer na organização em virtude de um senso de obrigação moral com a mesma.

Jaros ( 1995) realizou um estudo avaliando o modelo de três componentes do comprometimento organizacional de Meyer e Allen concluiu que o comprometimento afetivo dos empregados com a organização é o mais importante dos componentes do comprometimento organizacional para predizer a intenção de rotatividade, e sugere que organizaçð̃es interessadas em reduzir voluntariamente o 
comportamento de rotatividade de seu pessoal, faça-o indiretamente, encorajando o comprometimento afetivo.

Meyer e Allen (1997), identificam as consequências do comprometimento organizacional, como a alta taxa de retenção dos empregados e a execução de serviços não solicitados, como parte do trabalho, no caso de empregados comprometidos afetivamente com a organização. Segundo eles, os funcionários são mais propensos a desenvolver o comprometimento afetivo quando são tratados de maneira justa pela organização, suas contribuições são valorizadas e têm o senso de competência ou sucesso no seu trabalho. Algumas práticas gerenciais também aumentam o comprometimento afetivo, tais como, Programas orientados para a . comunicação das metas e valores da organização, treinamento e promoção decorrentes de políticas, divisão de lucros da empresa com os empregados, participação dos empregados nas decisð̃es da empresa, comunicação aberta entre gerentes e empregados e a percepção de justiça nas decisð̃es de pessoal.

Levinson (1999) afirma que comprometimento significa lealdade mútua e confiança entre as pessoas, o seu líder e a organização. Quando o comprometimento é forte, a organiząãa pode passar por turbulências e conquistar bons resultados.

Oliveira et alli (1999) afirmam que o comprometimento do indivíduo com a organização constitui alto beneficio para ambos e que empregados comprometidos com a organização tendem a engajar-se em comportamentos extrapapel, como criatividade ou inovação, o que mantém a organização competitiva.

Mathieu e Zajac (in Ricco, 1998), após analisarem 124 estudos publicados entre 1967 e 1987, classificaram as variáveis utilizadas nessas pesquisas como antecedentes, correlatas e consequentes. 
Como antecedentes estão as características pessoais, as características do trabalho, as relaçð̃es com o grupo e com o líder, as características organizacionais e status da função. Como variáveis correlatas as comprometimento organizacional figuram a motivação, a satisfação no trabalho, o stress e o

envolvimento com o trabalho. E como consequentes, estão a performance no trabalho, as alternativas de trabalho, a intenção em procurar novo emprego, a intenção em deixar a organização, a pontualidade, a rotatividade, o comparecimento ao trabalho e a permanência na organização.

Bastos (1992) refere-se ao comprometimento com a carreira, como o sentimento de identificação psicológica do indivíduo com a sua profissão, da qual seu trabalho atual faz parte. Morrow (1993) acrescenta que o comprometimento com a carreira implica a escolha intencional de uma linha de trabalho e a expectativa de que lealdade a essa escolha transcenderá um trabalho em particular ou um contexto organizacional.

\subsubsection{Instrumentos para Avaliar o Comprometimento Organizacional}

Meyer, Allen e Smith desenvolveram um instrumento que aborda a tridimensionalidade do comprometimento organizacional. É composto de 18 itens em uma escala de 1 a 5 (concordo totalmente, concordo pouco, nem concordo nem discordo, discordo pouco e discordo totalmente). Os seis primeiros indicadores referem-se ao comprometimento afetivo, os seis seguintes a comprometimento instrumental e os seis últimos ao comprometimento normativo. Esse instrumento foi comprovado em realidade brasileira por Medeiros (in Ricco, 1998), como no quadro a seguir: 
Tabela 2 - Indicadores do Instrumento de Meyer, Allen e Smith

\section{INDICADORES DE COMPROMETIMENTO AFETIVO}

- Eu seria muito feliz em dedicar o resto da minha carreira nesta organização.

- Eu realmente sinto os problemas da organização como se fossem meus.

- Eu não sinto um forte senso de integração com a minha organização. *

- Eu não me sinto emocionalmente vinculado a esta organização.*

- Eu não me sinto como uma pessoa da casa na minha organização.*

- Esta organização tem um imenso significado para mim.

$\circ$

\section{INDICADORES DE COMPROMETIMENTO INSTR UMENTAL}

- Na situação atual, ficar com a minha organização é na realidade uma necessidade tanto quanto um desejo.

- Mesmo que eu Quisesse, seria muito dificil para mi deixar minha organização agora.

- Se eu decidisse deixar minha organização agora, minha vida ficaria bastante desestruturada.

- Eu acho que teria poucas alternativas se deixasse esta organização.

- Se eu já não tivesse dado tanto de mim nesta organização, eu poderia considerar trabalhar em outro lugar.

- Uma das poucas consequências negativas de deixar esta organização seria a escassez de alternativas imediatas.

$\mathbf{0}$

INDICADORES DO COMPROMETIMENTO NORMATIVO

- Eu não sinto nenhuma obrigação em permanecer em minha empresa. *

- Mesmo se fosse vantagem para mim, eu sinto que não seria certo deixar minha organização agora.

- Eu me sentiria culpado se deixasse minha organização agora.

- Esta organização merece minha lealdade.

- Eu não deixaria minha organização agora porque tenho uma obrigação moral com as pessoas daqui.

- Eu devo muito à minha organização.

* Possuem valor invertido no sentido da frase e portanto deve-se interpretá-los observado este detalhe. Fonte: Extraído e adaptado de Medeiros, 1997

Em 1996, Stum conduziu uma pesquisa com 600 participantes e, baseado nesse estudo e em estudos anteriores, criou o WCI - Workforce Commitment Index, que é um indicador comportamental que mensura três dimensões do comprometimento do empregado em seis questð̃es, identificadas no desenvolvimento da pesquisa, apresentadas a seguir: 
Tabela 3 - WCI - Workforce Commitment Index

\begin{tabular}{|l|l|}
\hline \multicolumn{1}{|c|}{ Dimensão } & \multicolumn{1}{c|}{ Questōes } \\
\hline Desenvolvimento de times & $\begin{array}{l}\text { As pessoas com quem trabalho fazem esforços } \\
\text { pessoais para melhorar as suas habilidades, de forma } \\
\text { que possam fazer melhores contribuições ao trabalho } \\
\text { deles. } \\
\text { As pessoas com quem eu trabalho fazem sacrifícios } \\
\text { pessoais quando solicitadas para ajudar nosso grupo de } \\
\text { trabalho. }\end{array}$ \\
\hline $\begin{array}{l}\text { Eu poderia recomendar os produtos e serviços da } \\
\text { minha empresa como os melhores que um cliente pode } \\
\text { adquirir. } \\
\text { Eu recomendaria a minha empresa como um dos } \\
\text { melhores lugares para se trabalhar na minha } \\
\text { comunidade. }\end{array}$ \\
\hline $\begin{array}{l}\text { Eu pretendo permanecer na empresa por vários anos. } \\
\text { Eu permaneceria na empresa mesmo com uma oferta } \\
\text { de trabalho similar com pequeno aumento de salário }\end{array}$ \\
\hline
\end{tabular}

Fonte: Stum, 1996

De acordo com Ricco, (op.cit.), O estudo de comprometimento organizacional conta com outros instrumentos de medida já validados, inclusive na realidade brasileira como é o caso do OCQ (Organizational Commitment Questionnaire), que é formado por quinze indicativos e mede o comportamento afetivo, ou a permanência do indivíduo na organização porque ele quer ficar. Sua validação data de 1979 e é atribuída aos trabalhos desenvolvidos por Mowday, Porter e Steers. No Brasil o instrumento foi testado por Siqueira em 1989 e por Borges-Andrade, Afanasief e Silva, em 1993. 


\subsubsection{Como conquistar o comprometimento dos emprepados}

Em um contexto que enfrenta "downsizings", fusð̃es e incorporaçð̌es, reduçð̃es de funcionários e mudanças turbulentas, manter um empregado comprometido e identificado com a empresa e alinhado a missão da organização ou de sua unidade não é tarefa fácil.

Dessler, 1999, apresenta açð̌es para conquistar e implementar o comprometimento entre os funcionários. São elas:

- Comprometer com os valores básicos das pessoas, escrevendo-os, empregandos gerentes alinhados e fazendo o que se diz;

- Clarificar e comunicar a sua missão, esclarecendo a missão e ideologia, tornandoa carismática, usando práticas baseadas nesses valores para contratação, efetuando treinamento e orientaçð̃es sobre o estresse e construindo uma tradição;

- Garantir uma justiça organizacional, tendo procedimentos de compreensão aos ressentimentos e estabelecendo uma comunicação de duas vias;

- Criar um senso de comunidade, através da homogeneidade, trabalho de equipe e divisão igualitária;

- Dar suporte ao desenvolvimento dos empregados, apoiando o seu desenvolvimento, comprometendo-se com a atualização, concedendo o primeiro ano como desafio, enriquecendo-os e capacitando-os, concedendo atividades de desenvolvimento e, mantendo a segurança no emprego, sem dar garantias.

Levinson, 1999, afirma que os líderes alcançam o comprometimento seguindo as leis naturais e princípios que governam todas as interações humanas. Princípios são autovalidados, auto-evidentes e verdades universais. Eles constituem um compasso da 
organização. Existe uma similaridade entre a lei natural e as leis físicas básicas, como a conservação da massa e energia. Muitas fórmulas de engenharia são derivadas das leis básicas, como "força é igual a massa vezes aceleração". A maioria dos princípios do comportamento organizacional nasceram das leis naturais.

Ainda segundo Levinson, a utilidade mútua é a melhor forma de descrever os princípios básicos do comportamento organizacional. Uma organização existe porque todos os seus acionistas são úteis para cada um. Os empregados obedecem as diretrizes e servem à organização por que a organização os sustenta. Esse suporte vai além das necessidades físicas, incluindo a atualização e reconhecimento. Os clientes também apóiam a organização porque ela thes oferece bens e serviços úteis. Esse sistema, porém, não pode dar mais valor e benefícios do que pode criar.

Flexibilidade organizacional, adaptabilidade e rapidez contam com a capacitação e direcionamento dos empregados, e estes resultam em comprometimento. O direcionamento requer de todos o compartilhamento de uma visão comum e o uso de um mesmo compasso, segundo Levinson (op.cit.).

Stum (op.cit.) investigou uma lista de 80 itens que direcionavam para o comprometimento da força de trabalho, organizando-os em cinco categorias da vida organizacional, que compð̃em uma estratégia para construir um novo comprometimento:

- Equilíbrio entre o trabalho e a vida das pessoas, reconhecendo a importância da família e a vida pessoal do empregado, dando condiçð̃es aos empregados de equilibrarem o trabalho com outras partes de sua vida e incentivando os colegas de trabalho a apoiar as necessidades pessoais do empregado. 
- Benefícios e Remuneração, com pagamento equiitativo entre toda a organização, com programas de compensaçăo entendíveis, benefícios competitivos com outros empregadores e com uma comunicação adequada.

- Cultura organizacional, liderança e direção, com a empresa alinhada a uma correta direção, com os funcionários satisfeitos com a rotina de trabalho, criando oportunidades para crescimento pessoal e com o ambiente de trabalho com comunicação franca e aberta.

- Gerenciamento da mudança, com gerentes encorajando as idéias dos empregados para melhoramentos, envolvendo os empregados no planejamento de mudanças e estando pronto para fazer as mudanças necessárias para permanecer competitivo.

- Seleção, treinamento e desenvolvimento, avaliando o desempenho dos empregados, reconhecendo o seu desempenho e contribuiçð̃es e capacitandoos.

Walton, 1997 faz uma análise entre a estratégia do controle e a estratégia do comprometimento. A estratégia do controle é uma abordagem tradicional, adotada em resposta à divisão do trabalho em cargos pequenos, fixos, pelos quais os indivíduos pudessem se responsabilizar, sustentada em uma hierarquia de papéis alocados top-down, característica do modelo Taylorista.

$\mathrm{Na}$ estratégia do comprometimento, segundo Walton, as atividades são projetadas para serem mais amplas, combinando planejamento e implementação e incluindo esforços para aperfeiçoar as operações e não apenas mantê-las. Espera-se que as responsabilidades individuais mudem à medida que as condiçð̃es mudam, e as equipes, não os indivíduos, sejam as unidades organizacionais responsáveis pelo 
desempenho. As políticas de recompensa devem dar maior importância às conquistas do grupo, ampliar o escopo da preocupação individual e a preocupação com questð̃es como igualdade na distribuição de ganhos, opção de compras de açð̃es e distribuição de lucros. Igualmente importante na estratégia do comprometimento é o desafio de conceder aos funcionários a garantia de segurança, oferecendo -lhes prioridade em treinamento e retreinamento à medida que os antigos cargos são eliminados e são criados novos. Garantir aos funcionários o acesso ao processo apropriado e oferecerlhes formas de terem voz em questőes como métodos de produção, resolução de problemas e políticas e práticas de recursos humanos também são importantes na estratégia de comprometimento.

\subsubsection{Consideracões sobre Comprometimento}

Em todas as referências, o que fica bastante evidente é a importância de uma nova maneira de gerenciar as pessoas em uma organização, para a obtenção de resultados positivos.

Na relação empregado - empresa , a transparência, a confiança, o respeito pelas necessidades pessoais, o reconhecimento, a adoção de políticas e práticas voltadas para o desenvolvimento dos empregados que garantem a justiça organizacional com igualdade de tratamento e a participação dos empregados nas tomadas de decisões são alguns itens mencionados pelos autores pesquisados como importantes para se conquistar o comprometimento organizacional. Essas abordagens também são contempladas nos programas de Qualidade de Vida no Trabalho, o que pode indicar 
que existe uma correlação estreita entre os programas de QVT e a obtenção do comprometimento dos empregados com a empresa em que trabalha.

A liderança também tem uma grande responsabilidade, não só gerenciando as mudanças, mas principalmente estando comprometida a comprometer. 


\subsection{A PESQUISA DE DADOS SECUNDÁRIOS}

Para a análise e avaliação da importância dos Programas de Qualidade de Vida no Trabalho, dentro das políticas de Gestão de Pessoas que serão adotadas nos próximos anos, serão utilizadas como referências as pesquisas RH-2010 (Fischer e Albuquerque, 2001) e Focando o Futuro: RH no século 21(Ellig e Minehan, 1997), como fonte de dados secundários, produzindo informaçðes de dados estatísticos obtidos de diferentes especialistas da área, quando questionados sobre as principais tendências de Recursos Humanos para os próximos anos.

Os dois trabalhos foram realizados, utilizando-se a metodologia Delphi. A Metodologia Delphi é considerada uma Técnica Qualitativa de Pesquisa Prospectiva. Segundo Wheelwright e Makridakis (1973), os métodos prospectivos são utilizados quando não há dados históricos disponíveis. Esses métodos são adequados, basicamente, para dois tipos de situaçðes: Para prever quando um novo processo ou produto será largamente adotado e quais novos desenvolvimentos ou descobertas ocorrerão em uma área específica. Ainda segundo ele, os métodos de pesquisas qualitativas de prospeç̧ão não fornecem procedimentos detalhados ou um único ponto de previsão como outras técnicas quantitativas de prospeç̧ão.

\subsubsection{A Pesquisa RH-2010}

O PROGEP - Programa de Gestão de Pessoas da FIA/FEA/USP - Fundação Instituto de Administração da Universidade de São Paulo e sua linha de pesquisa longitudinal denominada "Observatório de Recursos Humanos", visando obter 
argumentos importantes para a teoria organizacional que contribuam para a prática de gestão de pessoas nas organizações, realizou uma pesquisa sobre tendências da Gestão de Pessoas nas empresas brasileiras - a RH-2010.

Esta pesquisa foi realizada com o objetivo de obter informações e subsídios para identificar os rumos que a Gestão de Pessoas das empresas deverá seguir nos próximos dez anos.

A metodologia utilizada foi a Técnica Delphi, bastante recomendada para a previsão de cenários futuros. O painel de respondentes foi selecionado usando-se como critérios: profissionais que integram as melhores e maiores empresas classificadas pela revista Exame, professores das principais universidades do Brasil e consultores de expressão na área. Foram realizadas duas rodadas da pesquisa. A primeira rodada contou com a participação de 168 profissionais e na segunda etapa, 120 participantes responderam às mesmas questões à luz dos resultados estatísticos apurados na primeira rodada, tendo a oportunidade de reavaliar sua posição.

Já na primeira etapa verificou-se um grau de consenso relativamente alto, que se manteve e foi mais acentuado na Segunda rodada. Os resultados finais foram analisados em um workshop, para o qual foram convidados todos os participantes da pesquisa. Neste encontro, através de uma dinâmica previamente estruturada, o grupo pôde aprofundar e qualificar os resultados do levantamento.

Para o objeto do atual trabalho, serão utilizados apenas os dados relativos às Políticas de Gestão de Pessoas, uma vez que é neste segmento da pesquisa RH-2010 que o Programa de Qualidade de Vida é abordado.

Os dados estatísticos são apresentados a seguir: 
Tabela 4 - RH- 2010 Políticas e Gestão de Pessoas

\begin{tabular}{|c|c|c|c|c|c|c|}
\hline $\begin{array}{c}\text { Relevân } \\
\text { cia }\end{array}$ & POSTo & Políticas de Gestão de Pessoas & É Relevante & $\begin{array}{c}\text { Já foi } \\
\text { Introduzida }\end{array}$ & $\begin{array}{c}\text { Será } \\
\text { Incorporada }\end{array}$ & $\begin{array}{c}\text { Grau de } \\
\text { dificuldade } \\
\text { (1 a 5) }\end{array}$ \\
\hline \multirow{8}{*}{$\frac{4}{2}$} & 01 & $\begin{array}{l}\text { Feedback freqũente aos funcionários sobre sua } \\
\text { atuação }\end{array}$ & $100 \%$ & $52 \%$ & $94 \%$ & 3,45 \\
\hline & 02 & $\begin{array}{l}\text { Utilização intensiva de meios informatizados de } \\
\text { auto aprendizagem }\end{array}$ & $98 \%$ & $37 \%$ & $97 \%$ & 3,28 \\
\hline & 03 & $\begin{array}{l}\text { Ênfase às necessidades bio-psico-sociais dos } \\
\text { empregados }\end{array}$ & $97 \%$ & $32 \%$ & $89 \%$ & 3,38 \\
\hline & 03 & $\begin{array}{l}\text { Práticas de monitoramento contínuo do } \\
\text { ambiente organizacional }\end{array}$ & $97 \%$ & $52 \%$ & $94 \%$ & 3,16 \\
\hline & 03 & $\begin{array}{l}\text { Parcerias com Instit. Extemas p/ promoção de } \\
\text { programas de desenvolvimento. }\end{array}$ & $97 \%$ & $72 \%$ & $92 \%$ & 2,66 \\
\hline & 04 & $\begin{array}{l}\text { Gestão de Carreiras p/ compatibilizar projetos } \\
\text { de desenvolvimento com desenvolvimento } \\
\text { Organizacional. }\end{array}$ & $96 \%$ & $23 \%$ & $91 \%$ & 3,76 \\
\hline & 04 & Utilização de meios de educação à distância & $96 \%$ & $28 \%$ & $97 \%$ & 3,37 \\
\hline & 05 & $\begin{array}{l}\text { Remuneração vinculada à capacidade de entrega } \\
\text { do funcionário }\end{array}$ & $95 \%$ & $36 \%$ & $92 \%$ & 3,72 \\
\hline \multirow{3}{*}{$\sum_{2}^{\frac{1}{2}}$} & 06 & $\begin{array}{l}\text { Políticas diferenciadas de acordo com os grupos } \\
\text { ocupacionais }\end{array}$ & $90 \%$ & $76 \%$ & $95 \%$ & 3,00 \\
\hline & 06 & $\begin{array}{l}\text { Maior poder de decisão das chefias sobre a } \\
\text { remuneração de sua equipe }\end{array}$ & $90 \%$ & $37 \%$ & $86 \%$ & 3,48 \\
\hline & 07 & $\begin{array}{l}\text { Beneficios flexíveis, com a participação do } \\
\text { funcionário na sua elegibilidade }\end{array}$ & $85 \%$ & $10 \%$ & $89 \%$ & 3,65 \\
\hline \multirow{3}{*}{ 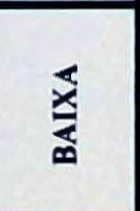 } & 08 & $\begin{array}{l}\text { Beneficios proporcionalmente menores na } \\
\text { remuneração }\end{array}$ & $71 \%$ & $30 \%$ & $92 \%$ & 3,41 \\
\hline & 09 & Opção aos funcionários de serem acionistas & $66 \%$ & $18 \%$ & $64 \%$ & 3,97 \\
\hline & 10 & Controle mais restrito de verbas remuneratórias & $59 \%$ & $64 \%$ & $91 \%$ & 3,27 \\
\hline
\end{tabular}

Fonte : Fischer e Albuquerque, 2001 


\section{Tabela 5 - WORKSHOP RH-2010}

O Workshop RH-2010 teve como objetivo analisar, consolidar e aprofundar os resultados finais obtidos pela pesquisa, através de debates entre os formadores de opinião e relato de casos concretos que exemplificaram as Tendências de Mudanças em Gestão de Pessoas para os próximos dez anos.

Os resultados das duas rodadas foram apresentados em plenário e, após a apresentação, os participantes foram divididos em grupos. Cada grupo recebeu o resumo dos resultados e discutiu um tópico específico da pesquisa, apresentando o consenso alcançado. A seguir, o resumo do consenso alcançado pelos grupos:

- Tendências de Mudança nas Políticas de Gestão de Pessoas

O grupo selecionou como tendências mais relevantes a Ênfase às necessidades biopsico-sociais dos empregados, Gestão de carreiras para compatibilizar projetos de desenvolvimento com desenvolvimento organizacionais, Feedback freqüente aos funcionários sobre sua atuação e Beneficios flexiveis, com participação do funcionário na sua elegibilidade

Fonte : Fischer e Albuquerque, 2001

Nos resultados estatísticos das duas rodadas de questionário, a Os programas de Qualidade de Vida no Trabalho ocuparam o terceiro lugar de relevância entre as políticas de recursos humanos abordadas (97\%), com um pequeno percentual (32\%) de empresas que já introduziram essa política na organização, com uma projeção de $89 \%$ de empresas que pretendem desenvolver esses programas nos próximos anos.

Quando esses dados foram discutidos no workshop, a releváncia dos programas de Qualidade de Vida no Trabalho não só foi confirmada, como foi apontada como uma das políticas de RH mais importantes para os próximos anos. 


\subsubsection{A Pesquisa Focando o Futuro: RH no Século 21}

Esta pesquisa também foi realizada com a utilização da metodologia Delphi, em 1997, por ELLIG, B.R. E MINEHAN,M. com especialistas da área de Gestão de Pessoas para apurar as tendências dos Recursos Humanos para o século 21. Apenas serão utilizados os dados do capítulo 2, pois é nele que se referem à Qualidade de Vida no Trabalho. São eles:

CAP. 2 - RECURSOS DE MÃO-DE-OBRA NO MUNDO EM MUDANÇA

A seguinte pergunta foi: Como as empresas utilizarão os recursos de mão-de-obra no

futuro? Esses são os seguintes pontos de consenso:

$>$ Em uma primeira hipótese de cenário, as organizaçð̃es se tornarão esvaziadas e mais virtuais, ainda que as estruturas existentes não desaparecerão completamente e a metamorfose demorará mais que o previsto. Os indivíduos formarão alianças para um determinado projeto tendo em comum um empregador. $O$ pequeno grupo de empregados efetivos permaneceria com a parte formal da organização, com o empreendimento de desenvolver um grupo de indivíduos capacitados para trabalhar "just in time". (pg. 54)

$>$ Em uma segunda hipótese, uma grande maioria das empresas continuaria a existir como uma organização tradicional, com facilidades reais e empregados reais. Trabalhos à distancia e em casa podem aumentar, mas problemas decorrentes como segurança, supervisão, habilidade para determinar quem está efetivamente fazendo o trabalho e perda do contato pessoal atrapalharão o maior crescimento. Além disso, governos e sindicatos oferecem resistência à mudanças no modelo da base contratual de emprego atual. (pg. 55)

$>$ Os dois cenários propostos concordam que, independente das estruturas, os negócios no futuro serăo organizados para proteger a essência das competências. A habilidade mais valiosa de um executivo não será reduzir a força de trabalho, mas a aptidão de inspirar e encorajar a que existe hoje. (pg. 55)

$>$ A força de trabalho será crescentemente bipolar, continuando uma tendência existente. Acesso a informação e oportunidades globais, equidade dos empregadores, e um pacote de remuneração competitivo mundialmente serão essenciais para manter $o$ núcleo do grupo. A diferença salarial entre trabalhadores qualificados e não-qualificados se acentuará. (pg. 55)

$>\mathrm{O}$ contingente da força de trabalho será melhor tratado no que se refere a planos de compensação e benefícios, recebendo tratamento similar ao dos empregados efetivos. (pg. 55) 
As saídas para o desenvolvimento de carreiras e habilidades serão determinadas juntamente entre empregados e empresa. Os governos continuarão a supervisionar a educação básica e as empresas trabalharão juntas com os governos para identificar as habilidades necessárias. $\left(\mathrm{Pg} . \mathrm{56}^{6}\right)$

$>$ Tecnologia e setor privado desenvolverão papel crítico no desenvolvimento de programas de treinamento. As empresas voltadas para a educação deverão identificar a necessidade de conhecimento e desenvolvimento de habilidades das organizações, oferecendo os serviços, sempre de forma temporária. (Pg. 56)

$>$ A nova relação entre empregado e empregador será caracterizada pelo relato individual e desempenho baseado na segurança contra o domínio ou serviço baseado na segurança do passado. Ter boa performance e ser vital para a missão da empresa serão indicadores para se manter nela. As empresas deverão estar preparadas para o aumento de turn-over. (pg. 57)

$>$ Os empregadores continuarão a pôr mais ênfase na adaptação do local de trabalho às necessidades dos empregados, com programas trabalho/vida como forma de atrair, reter e motivar a força de trabalho desejada. (pg. 57)

$>$ Flexibilidade no que diz respeito a remuneração e benefícios será crucial para atrair e reter funcionários valiosos. Os negócios globais trarão variedade na maneira como as pessoas serão remuneradas e treinadas. Negociações com agencias governamentais serão vitais (pg. 57).

$>$ A tendência emergente de contas individuais, pelo menos nos EUA, para planos de saúde, pensão, e outros benefícios continuará a se desenvolver, nacional e globalmente. (pg. 58)

Fonte:, ELLIG, B.R. E MINEHAN,M, 1997

Apesar deste trabalho ter sido realizado utilizando um outro universo pesquisado, dentro do contexto organizacional americano, a preocupação com o equilíbrio entre trabalho e vida pessoal dos empregados também está presente entre os especialistas em gestão de pessoas

Uma terceira pesquisa foi encontrada na revisão de literatura, que também relaciona a importância da QVT para a Gestão de Pessoas. Ela foi realizada pela William M. Mercer Inc., em 1996, com 800 funcionários de diversas organizaçð̃es. Os resultados obtidos foram os seguintes (Vallario, 1997): 
- $86 \%$ concordaram que uma empresa não conseguirá continuar competitiva nos próximos anos sem encontrar o equilibrio entre o trabalho do empregado e sua vida pessoal.

- $64 \%$ acreditam que o programa de QVT aumentou o moral do grupo.

- $50 \%$ acharam que o programa ajudou a cortar o absenteísmo.

- $47 \%$ acreditam que auxiliou no aumento de produtividade.

Nestes três trabalhos citados, observa-se que os Programas de Qualidade de Vida no Trabalho estão sendo considerados como importante preocupaçăo dos especialistas da área de Recursos Humanos, relacionados, inclusive, com a competitividade, produtividade, diminuição do absenteísmo e melhoria do moral do grupo, conforme indica o estudo realizado pela William Mercer Inc. (op.cit).

O estudo realizado pela FIA/USP tem especial relevância, por ter investigado especialistas brasileiros, contextualizados na mesma realidade deste trabalho de investigação. Em todos, houve convergência de resultados. 


\section{4 - A ALIMENTAÇÃO E NUTRIÇÃO}

José Carlos Tartaglia (1996) procurou mostrar o seu entendimento do papel da alimentação na reprodução da força de trabalho e sua relação com o movimento do capital no processo de desenvolvimento. Segundo ele, o problema da alimentação e nutrição deveria ser de responsabilidade da sociedade e não somente de cada cidadão. O significado disso seria o desenvolvimento do conceito de segurança alimentar com a participação do Estado, das Empresas e dos Cidadãos. E é na esfera das Empresas que o atual projeto será desenvolvido, verificando de que maneira elas contribuem para que não só os empregados, mas também os seus familiares tenham boas condiçð̃es de desenvolvimento fisico e mental.

Segundo Comolazio (1972), três condiçð̃es básicas são consideradas fatores importantes para uma performance adequada no trabalho: condiçðes gerais (físicomentais) do indivíduo não enfraquecidas, adaptação e controle sobre o meio ambiente e finalmente, nutrição adequada.. Nutrição adequada é requerida pelo corpo humano para satisfazer as necessidades específicas de reposiçăo, a taxa de metabolismo basal, a construção e reposição dos tecidos do corpo, a atividade dinâmica da especificidade dos alimentos e os requisitos dos diversos niveis de trabalho muscular .

Campino et al. (1982), afirma que o processo de trabalho implica por definição, em desgaste da força de trabalho. Neste sentido, um suprimento não adequado às necessidades vitais tem implicaçðes sobre

a produtividade. Dentre as necessidades vitais, o não suprimento adequado de alimentação implica obrigatoriamente em desgaste rápido da força de trabalho, 
elevados índices de acidentes de trabalho, absenteísmo, assim como em descontinuidade na produtividade, face à menor capacidade produtiva dos trabalhadores e sua insatisfação manifesta.

Um outro aspecto importante a ser considerado dentro da alimentação, está relacionado com a ingestão excessiva de açúcares e gorduras e a ocorrência de enfermidades crônico não transmissiveis, como doenças cardiovasculares, o diabetes mellitus, não insulino-dependente, diferentes tipos de câncer e mesmo a obesidade. Mondini et al. (1995), analisam essa problemática afirmando que, mediante dieta adequada em quantidade e qualidade o organismo adquire energia e os nutrientes necessários para o bom desempenho de suas funções e para a manutenção de um bom estado de saúde. De longa data conhecem-se os prejuizos decorrentes quer do consumo alimentar insuficiente - deficiências nutricionais - , quer do consumo alimentar excessivo - obesidade. A associação entre o consumo de gorduras saturadas e a ocorrência de doença coronariana e o consumo de origem animal e a ocorrência de câncer de cólon, próstata e mamas, são exemplos clássicos de uma alimentação inadequada.

Muller (1983), fazendo uma análise da nutrição e do desenvolvimento econômico chama a atenção para alguns aspectos importantes:

- Nos últimos $\mathbf{4 0}$ anos, ocorreu uma mudança na organização social brasileira: de predominantemente agrária para predominantemente urbana-industrial;

- Nesse movimento de mudança histórica, os custos agrícolas dos produtos alimentícios - antes praticamente inexistentes - passaram a fazer parte, lado a lado com os custos de armazenagem, transporte, comercialização e custos financeiros, do preço final dos elementos; 
- Nesse processo ocorreu uma alteração no padrão alimentar, isto é , houve uma alteração da participação dos vários itens no total do consumo e dos gastos com alimentos - processo este, com certeza mais nítido nos centros urbanos do sul do país e menos nos centros do Norte e Nordeste,

- mais acentuados em todas as classes de renda do sul que nas classes de baixa renda do Norte e Nordeste;

- A mudança no padrão alimentar não significa, necessariamente, melhoria nutricional para todas as classes de renda da sociedade brasileira.

Mondini (op. cit) fazendo uma análise de pesquisas sobre o consumo alimentar realizadas de 1961 a 1988 (POF 61/63, ENDEF 74/75 e POF 87/88), observando as mudanças no padrão de alimentação dos brasileiros nesse período, constatou que:

- Houve redução do consumo de cereais e derivados, feijão, raízes e tubérculos, observada principalmente na passagem da década de 70 para 80.

- Houve um aumento contínuo do consumo de ovos, leite e derivados;

- A banha, toucinho e manteiga foram substituídos por óleos vegetais e margarinas;

- O consumo de carnes aumentou, principalmente a partir da segunda década de 70.

- O açúcar compőe $1 / 4$ do total de carboidratos da dieta nos três inquéritos, havendo pouca variação entre as regiōes Nordeste e Sudeste;

- A tendência de consumo de proteinas de origem animal é crescente nas duas regiðes.

É interessante notar, a principio, que a tendência brasileira de reduzir o consumo de ccreais e tubérculos, de substituir carboidratos por lipídios e de trocar proteína 
vegetais por proteínas animais, repete situação verificada, em décadas passadas em países desenvolvidos e mais recentemente, em alguns países em desenvolvimento. O reconhecimento de que características da dieta possam exercer influência decisiva sobre o estado de saúde dos indivíduos determinou que a Organização Mundial de Saúde (OMS) estabelecesse guias alimentares que definiram limites seguros para o consumo de gorduras, colesterol, açúcar, entre outras substâncias (WHO, 1990) Mondini (op.cit.) demonstra preocupação ao constatar que o consumo relativo de gorduras na Região Sudeste, acusado pela POF/88, já ultrapassa o limite máximo recomedado pela Organização Mundial de Saúde.

Uma segunda preocupação se refere ao consumo excessivo de açúcar presente nos três inquéritos e em todas as áreas estudadas. Uma terceira preocupação diz respeito ao consumo insuficiente de carboidratos complexos, evidenciando desde o inquérito de 1962 na regiåo Sudeste e revelado na Região Nordeste pelo último inquérito (1988).

\subsubsection{Importância dos nutrientes para a saúde e diminuicão do risco de doencas}

É através da alimentação que o organismo consegue receber os nutrientes necessários para manter-se saudável e resistente a doenças. Esta constatação não $\varepsilon$ novidade. Os imperadores romanos, já naquela época, sabiam que o desempenho dos seus soldados nas batalhas dependia da alimentação que thes era dada. Outra observação histórica, é a constatação feita em uma viagem ao redor do mundo em navio, no ano de 1747 por James Lind, que a laranja e o limão eram eficientes no combate ao escorbuto, 
doença relacionada à falta de vitamina $\mathrm{C}$, que acometia a tripulação dos militares $\mathrm{e}$ marinheiros da época (Alrin-Slater \& Kritchevsky, 1980)

Dentro da visão biopsicossocial de QVT, já mencionada, o ser humano reage como um todo complexo, interligado pelas dimensões biológicas, psicológicas e sócias. E é na dimensão biológica, onde estão incluídos os sistemas que promovem o funcionamento do corpo humano, o metabolismo, as resistências e as vulnerabilidades do corpo, que a alimentação se torna importante objeto de estudo neste trabalho (Anexo 1). 


\section{5 - AS CONSEQUÊNCIAS DE UMA ALIMENTAÇÃo INADEQUADA}

A grande heterogeneidade econômica, social e cultural que caracteriza os países em desenvolvimento, acaba produzindo um mosaico de situações discrepantes (Monteiro et al, 2000), como no caso do Brasil, onde convivemos com a fome e desnutrição em determinadas regiões, geradas pela alimentação inadequada caracterizada pelo baixo acesso e ingestão de alimentos dos indivíduos e por outro lado um desbalanceamento energético ocasionado pela seleção inadequada de hábitos alimentares com a ingestão excessiva de açúcares e gorduras, conforme vimos anteriormente.

É nessa segunda situação que iremos concentrar o atual trabalho, apresentando a seguir, uma revisão bibliográfica sobre a obesidade e as patologias não transmissiveis relacionadas a ela.

\section{$\underline{\text { 1.5.1 - Obesidade }}$}

A obesidade se define como uma doença caracterizada pela acumulação excessiva de gordura corporal que origina um prejuizo à saúde do individuo. Em populações adultas, o índice de massa corporal (IMC) dos indivíduos é o parâmetro escolhido para calcular a incidência da obesidade (WHO, 1998). O cálculo do IMC é obtido através da divisão do peso em quilogramas pelo quadrado da altura em metros. Há duas décadas, Keyes e col. sugeriram chamar a correlação MC.(EST $\left.{ }^{-2}\right)$ de índice de Massa Corporal. A partir daí esta relação ficou popular na avaliação nutricional de adultos, isso porque o IMC é 
aparentemente o índice de melhor correlação com Massa Corporal (valores do coeficiente de correlação " $r$ " normalmente superiores a 0,80 ) e, principalmente, pela baixa correlação com estatura (normalmente " $r$ " em torno de 0,10 ), fato documentado internacionalmente em amostras de populaçð̃es adultas. (Anjos, L.A., 1992).

Ainda que o IMC não meça diretamente a proporção de gordura no corpo, estudos realizados em grandes mostras populacionais mostram uma elevada correlação entre o IMC e gordura corporal e, ainda mais importante, o notável aumento de riscos de mortalidade associada a elevados valores de IMC. Baseando-se nessa evidência, a OMS recomenda a classificação de pré-obesos para adultos com IMC de 25 a $29,29 \mathrm{Kg} / \mathrm{m}^{2}$ e de obesos para aqueles com IMC maior ou igual a $30 \mathrm{Kg} / \mathrm{m}^{2}$ (sendo obesidade de Grau I de 30 a 34,9; Grau II de 35 a 39,9; e Grau III $>40 \mathrm{Kg} / \mathrm{m}^{2}$ ) (Monteiro e Halpern, 2000)

Monteiro e Halpern (op. cit) observam que a obesidade é uma doença relativamente rara (1-3\%) em países extremamente pobres (PIB US\$100-400 per capita). Nos demais países, a incidência da obesidade não parece guardar relação com o nível de riqueza. O Japão e a Suécia, países que lideram o ranking de riqueza (US\$ 26.000 e US\$ 25.000 per capita de PIB, respectivamente) apresentam incidências relativamente baixas de obesidade $(2 \%$ e $5 \%$, respectivamente). Países menos ricos (PIB US $\$ 20.000$ a 23.000 per capita) como a Alemanha, estados Unidos e Canadá, apresentam incidências bastante elevadas de obesidade: $15-20 \%$ em homens e $15-25 \%$ em mulheres. Com níveis de riqueza similares (PIB perto de US\$17.000 per capita) os países Baixos e o Reino Unido apresentam incidências muito diferentes de obesidade: $8 \%$ e $13-16 \%$, 
respectivamente. Em países de PIB médio (US\$ $3.000-8.000$ per capita) a incidência de obesidade se mostrou particularmente elevada em mulheres: $13,3 \%$ no Brasil e $26,6 \%$ na Arábia Saudita e $27,9 \%$ na Rússia. Na população adulta masculina foram 5,5\%, 17,8\% e 10,8\%, respectivamente. Conclui-se, assim, que somente as sociedades extremamente pobres parecem estar de maneira natural e consistente protegidas da obesidade. Em níveis modestos de riqueza, como as observadas no Brasil se apresentam taxas muito elevadas de obesidade, em especial na população feminina. Por outro lado, a baixa incidência de obesidade no Japão, Suécia e, em menor extensão, nos Países Baixos, sugere que o desenvolvimento econômico e a magnitude da obesidade não são fenômenos necessariamente relacionados. Neste caso, aspectos culturais são, provavelmente, mais importantes que os aspectos econômicos.

Essa suposição é confirmada em outro estudo realizado por Monteiro et al. (op. cit), comparando as realidades urbana e rural brasileiras: Ele chegou à conclusão que no Brasil urbano, onde vive cerca de $\mathbf{8 0} \%$ da sua população, o nível sócioeconômico, adequadamente definido segundo a possessão de certos bens na residência e do tipo de ocupação, não se associa com risco de obesidade nas mulheres. Ou seja, as mulheres ricas e pobres estão igualmente com risco alto de obesidade. Por outro lado, a escolaridade das mulheres e o acesso à informação se relacionam inversamente - de forma independente e significativa - com risco de apresentação de obesidade. Nas mulheres urbanas, a proteção contra a obesidade não está orientada à pobreza ou ao maior gasto energético, mas sim a uma melhor educação e acesso à informação. 
Ao contrário, no Brasil rural, onde geralmente o nível de desenvolvimento é inferior, os fatores econômicos ainda săo muito importantes. As pessoas com salários mais altos da amostra, se associavam com maior probabilidade de mulheres obesas, enquanto que a maior escolaridade e o acesso à informação não tinham importância alguma. Os autores concluem que, em países onde a transição na dieta e nos padrōes de atividade física tem sido importantes, a obesidade e as patologias não transmissíveis relacionadas, se associarão inversamente com o nível socioeconômico na medida que se incrementam os níveis de educação e o acesso à informação.

Em países de desenvolvimento médio, as diferenças de renda continuam condicionando o acesso diferenciado a vários bens e serviços, mas não necessariamente à alimentação (especialmente de alimentos básicos). Por outro lado, os avanços tecnológicos no processo produtivo fazem que o gasto de energia no trabalho já não esteja tão relacionado com a classe social do indivíduo. Tanto os ricos como os pobres estão igualmente expostos à obesidade. O que diferencia nesta situação é o critério seletivo dos indivíduos com respeito à alimentação (quantidade e qualidade) e ao padrão de atividade física, definido pelas atividades realizadas nos momentos de ócio (Monteiro e Halpern, op.cit.). Atualmente, uma das principais enfermidades na área de saúde é a obesidade, que constitui uma das alterações metabólicas mais frequentes e de maior repercussão sócio-econômica (WHO 1998, in Pimenta, 2000).

Na Consensus Conference realizada em 1985 nos Estados Unidos (National Institutes of Health Consensus Development Panel 1985, in Garrow, 1988) concluiu: 
"A evidência é agora esmagadora que a obesidade, definida como armazenamento excessivo de gordura, tem efeitos adversos na saúde e longevidade. Obesidade é claramente associada com a hipertensão, hipercolesterolemia, diabetes melitus insulino não dependente e alguns tipos de câncer e outros problemas médicos... Trinta e quatro milhð̃es de adultos americanos tem o índice de massa corporal maior que 27,8 (homens) e $27,3 \%$ (mulheres). Nesse nível de obesidade, com $20 \%$ acima do índice desejável, o tratamento é altamente recomendado".

Garrow (op. cit.) aprofunda a discussão sobre a relação entre obesidade e as doenças associadas a ela. Ele cita o estudo realizado por Preston \& Clarke em 1966, onde as empresas de seguro interessadas em estudar as causas da mortalidade para a avaliação dos seguros mais rentáveis, concluiu que em uma amostra de homens com idade de 35 a 49 anos e 50 a 74 anos, as principais causas da morte em ambos os grupos, com peso normal e com sobrepeso de $20 \%$, foi doenças cardiovasculares e câncer, porém havendo uma taxa de mortalidade maior no grupo de obesos. Além dessas penalidades metabólicas citadas, associadas ao sobrepeso, ele cita também: os efeitos relacionados com a reprodução humana, uma vez que tanto mulheres muito magras como muito gordas, têm irregularidades na ovulação e no período menstrual; diminuição da tolerância para exercícios físicos podendo chegar à osteoartrite e incapacidade física; e, por último, os efeitos sociais e psicológicos sobre a pessoa obesa, uma vez que são pouco consideradas socialmente acarretando uma baixa auto-estima. 


\subsubsection{As Doencas Cardiovasculares}

A preocupação com a saúde dos funcionários e, em especial com as doenças cardiovasculares, tem estado presente nas empresas que planejam e desenvolvem programas de Qualidade de Vida no Trabalho, uma vez que elas constituem a principal causa de óbito no mundo (Neumann et al., 2000), além de vitimar cerca de 300.000 brasileiros por ano e representar importante motivo de absenteísmo e afastamento definitivo do trabalho (Lotufo, 1996). Estima-se que em 1985 o número de anos produtivos de vida perdidos no Brasil por mortalidade precoce (entre 15 a 59 anos) seja de 814.964 anos, uma média de 12,5 para homens e 13,4 para mulheres de anos perdidos/pessoas. Em 1991 estima-se um total de 1.300.000 anos de vida perdidos por doenças cardiovasculares, quando as doenças cardiovasculares representaram a primeira causa de morte da população brasileira e foram responsáveis por aproximadamente $34 \%$ dos óbitos totais do país. (Ministério da Saúde, 1993)

A participação das doenças cardiovasculares na mortalidade do país vem crescendo desde meados do século. Em 1950, apenas 14,2\% das mortes ocorridas nas capitais dos estados brasileiros eram atribuídas a moléstias circulatórias; passaram a $21,5 \%$ em $1960,24,8 \%$ em 1970 e $30,8 \%$ em 1980 . Em 1989,as doenças cardiovasculares contribuíram com $32,4 \%$ de todos os óbitos nas capitais dos estados brasileiros. Além de contribuírem de modo destacado para a mortalidade, as moléstias do aparelho circulatório são causas freqüentes de morbidade, implicando 10,74 milhões de dias de internação pelo Sistema Único de Saúde (SUS) e representando a principal causa de gastos em assistência médica: $16,2 \%$ do total. (Lotufo e Lolio, 2000). 
Uma pesquisa apresentada no $57^{\circ}$ Congresso da Sociedade Brasileira de Cardiologia, realizado em São Paulo no ano de 2002, mostrou que $40 \%$ dos brasileiros estão com o nível de colesterol acima do normal. Nos Estados Unidos, essa porcentagem é de $36 \%$. O resultado do estudo, que apurou a taxa de colesterol de 80 mil pessoas em várias cidades paulistas, surpreendeu os cardiologistas.

O limite de normalidade para o colesteral é de 200 em número miligramas por decilitros de sangue. Quem tem nível acimà desse valor entra para as estatísticas de indivíduo com colesterol alto - um dos fatores de risco para os enfartes. (Jornal O Estado de São Paulo, 23/09/2002)

O conhecimento dos fatores de risco de doenças coronárias veio de estudos epidemiológicos, experimentais com animais e clínicos, especialmente, os realizados em Framingham, uma pequena cidade perto de Boston, nos Estados Unidos, onde no final da década de 40 iniciou-se um estudo prospectivo, envolvendo 5.209 habitantes escolhidos aleatoriamente, todos saudáveis no início do estudo. Foram medidos parâmetros como peso, pulso, pressão arterial, hemograma, bioquímica do sangue, e colhidas informaçð̃es sobre o estilo de vida como vício de fumo, atividade física, etc. Os dados são reexaminados a cada dois anos e comparados com os dados do início do estudo, verificando a incidência de doença coronária. Tudo que foi medido e foi, mais tarde, associado com uma maior incidência de doença coronária ou acidente vascular encefálico, foi denominado Fator de Risco, ou seja, que desempenha um papel na produçăo da doença (Ministério da Saúde, op.cit) 
Cervato et al. (1997) afirmam que diversos estudos epidemiológicos, desde Framingham, tem fornecido uma visão sobre os fatores de risco envolvidos na etiologia da doença cardiovascular. Dentre eles, os mais importantes são a hipertensão arterial sistêmica (HAS), as dislipidemias (colesterol total, LDL, apolipoproteína B e trigliciderídeos aumentados e HDL diminuído), a presença de hipertrofia ventricular esquerda, a obesidade, o diabetes melito e alguns hábitos relacionados ao estilo de vida, como dieta rica em calorias, gorduras saturadas, colesterol e sal, consumo de bebida alcoblica, tabagismo e sedentarismo. A dieta, por sua vez, está presente na etiologia das dislipidemias, obesidade e pode atuar como agravante do diabetes melito. Neumann et al.( ops cit.), agregam a esses fatores, o estresse, o uso dos anticoncepcionais orais e os antecedentes familiares.

O Ministério da Saúde (op.cit.), classifica também, fatores de risco que não podem ser alterados, são eles : idade, sexo, raça e história familiar de doenças coronarianas. Estes não estão sendo avaliados no atual estudo.

\subsubsection{Recomendacões}

De acordo com Lotufo e Lolio (op.cit.), cabe ao serviço público de saúde coordenar os esforços da sociedade para reduzir a mortalidade e morbidade pelas doenças cardiovasculares, desestimulando o tabagismo, incentivando a adoção de hábitos dietéticos saudáveis e, principalmente, implementando uma campanha de massa para deteç̧ão, tratamento e controle da hipertensão arterial por meios dietéticos e farmacológicos. 
O relatório do Ministério da Saúde (op.cit) ratifica essa idéia, com um foco um pouco diferente. Segundo ele, em estudos realizados em outros países ficou demonstrado que houve um decréscimo dos índices de morbi-mortalidade por doenças coronarianas e por acidente vascular cerebral, em paralelo às mudanças nos hábitos de consumo da população, principalmente no tocante a alimentos e cigarros. Essa redução ocorreu sem que houvesse alterações significativas na oferta da prestação de serviços assistenciais de saúde, mas sim, com o incremento de programas educativos voltados para a promoção da saúde e mudança no estilo de vida população.

Cervato et al.(op.cit.) também concluem que os fatores de risco para doenças cardiovasculares não podem ser eliminados, mas alguns podem ser modificados. Segundo eles, a dieta habitual parece ser um elemento fundamental de análise dos determinantes da susceptibilidade para a arterosclerose e doenças isquêmicas do coração, não se podendo prescindir de informações sobre dieta para mudanças no comportamento alimentar e controle das morbidades em questão. Diversas investigações reforçam a importância de programas de intervenção, principalmente àqueles relacionados às mudanças do estilo de vida.

O comitê sobre Dieta e Saúde do Conselho de Pesquisa Nacional dos Estados Unidos (in Neumann, op.cit.) propõe, entre outras, as seguintes recomendações:

- Redução do consumo total de gordura para $30 \%$ ou menos do total de calorias.

- Redução do consumo de ácidos graxos saturados para menos de $10 \%$ de calorias e o consumo de colesterol para menos do que $300 \mathrm{mg} / \mathrm{dia}$. 
- Consumo de gordura e colesterol pode ser reduzido pela substituição das carnes gordas e dos produtos lácteos (derivados de leite integral) por carnes e leites com menor teor de gordura, e pela limitação na utilização de óleos, gorduras, gemas e alimentos fritos e outros muito gordurosos, escolhendo uma maior quantidade de hortaliças, frutas e cereais integrais.

- Consumir todos os dias cinco ou mais porções de uma combinação de hortaliças, frutas e cereais integrais, especialmente, vegetais verdes e amarelos e frutas cítricas.

- Aumentar o consumo de amidos e outros carboidratos complexos, consumindo seis ou mais porçðes diárias de uma combinação de pães, cereais, e manter o consumo de proteínas em níveis moderados.

- Limitar o consumo diário de sal total (cloreto de sódio) a $6 \mathrm{~g}$ ou menos.

\begin{abstract}
Além de seguir uma dieta com o objetivo de diminuir as concentrações de lipídios séricos o comitê também sugere ajustar o consumo de energia e nível de exercício físico para atingir e manter o peso corpóreo apropriado. Também, existe a evidência de que fibras alimentares desempenham importante papel na prevenção e controle de doenças cardiovasculares, por reduzir a densidade calórica, promover saciedade por aumentar o tempo de esvaziamento gástrico e diminuir a um pequeno grau a eficiência na absorção intestinal (Krummel, 1998). Um estudo realizado por Neumann et al (op.cit.) em 50 indivíduos de ambos os sexos, com idade entre 31 e 60 anos com doenças cardiovasculares, teve como resultado um guia nutricional que é uma adaptação da Pirâmide Alimentar: a Pirâmide Alimentar para indivíduos portadores de doenças cardiovasculares:
\end{abstract}


Figura 3 - Pirâmide Alimentar para portadores de doenças cardiovasculares

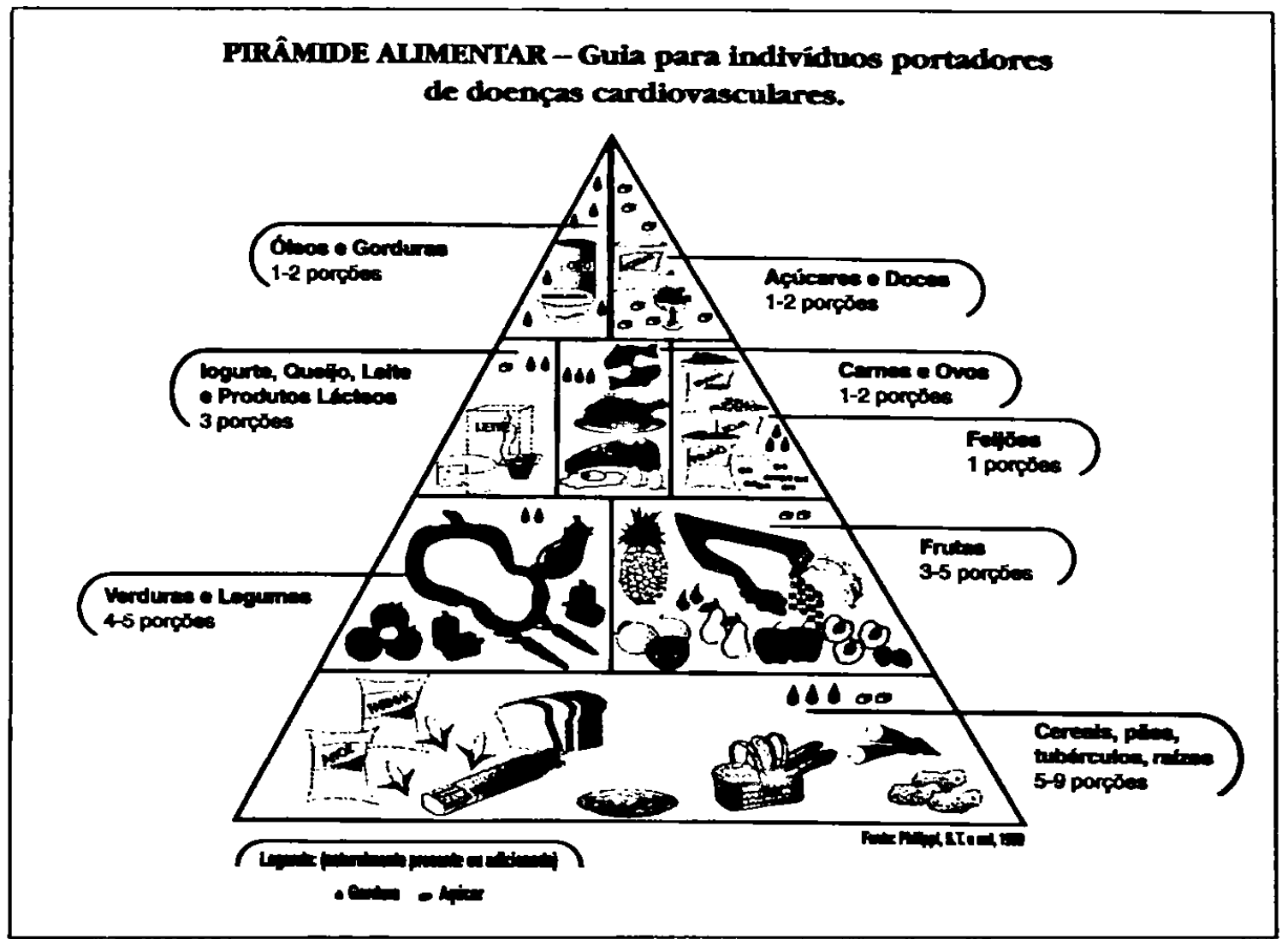

Fonte: Philippi. S.T. e col.. 1999

O presente trabalho tem como objetivo investigar a atuaçăo das organizações, independentemente das açőes governamentais, na orientação de alimentação e hábitos saudáveis que implicam na redução das ocorrências de doenças cardiovasculares, através dos Programas de Qualidade de Vida no Trabalho, cumprindo um importante papel social de promoção da saúde e bem-estar dos seus empregados. 


\section{6 - TEORIA DO CAPITAL HUMANO}

A "revolução" da Teoria do Capital Humano começou há quatro décadas atrás, segundo Becker (1993), tendo como pioneiros Ted Schultz, Jacob Mincer, Milton Friedman, Sherwin Rosen e vários outros autores da Universidade de Chicago.

Marshall é um outro autor de grande importância pela atualidade dos seus pensamentos. No final do século 19 , ele fez uma análise e discussão do papel do investimento em capital humano na erradicação da pobreza em massa e no processo de desenvolvimento. Marshall via no "caráter nacional", ou seja, nos atributos éticos e intelectuais da população "um dos mais valiosos entre todos os insumos da função de produção, um dos ingredientes mais decisivos na receita do crescimento econômico" (Reisman in Fonseca, 1992). Para Marshall, a análise do papel de capital humano no processo econômico baseia-se na idéia de que, para aumentar a produção per capita e vencer o atraso econômico, é necessário investir no fator de produção homem. Segundo ele, existe uma estreita relação entre nutrição, saúde e educação, de um lado, e capacidade de trabalho, iniciativa e inovação de outro. Existe um elo entre a pobreza e a incompetência, uma vez que a pobreza, o ambiente de privação material e a ignorância de uma geração torna-se o berço da incompetência da geração seguinte, formada por indivíduos impedidos de desenvolver as suas qualidades fisicas, morais e intelectuais das quais dependerá sua competência na vida prática e sua sobrevivência no mercado. $O$ capital humano foca o investimento em seres humanos, não apenas como uma questão humanitária mas como um investimento na formação de capital produtivo de uma nação (Fonseca op.cit.). 
A filosofia social marshalliana e sua análise sobre o investimento no capital humano como tendo um importante papel para o crescimento da economia de uma nação, através da obtenção de um trabalho qualificado, e da inovação científica e tecnológica está presente nos vários fóruns de discussð̃es realizados no Brasil de hoje, para a análise dos vários problemas econômicos e sociais existentes. Por exemplo, no I workshop de "Prospeç̧ão estratégica para o futuro" realizado em 31/03/00 pela FIA/FEA/USP, o professor Simão Silber apresentou como importante o investimento em educação para se reverter o processo de exclusão do mercado de trabalho de grande parte da população, que não teve acesso à escolaridade formal. Marshall, no século XIX, já defendia a importância do investimento na qualidade da força de trabalho para um programa de reforma social eficaz, voltado para a erradicação da pobreza e a promoção do desenvolvimento. Contudo, apenas recentemente o conceito de capital humano foi integrado na teoria econômica, permitindo a explicação do crescimento econômico e a construção de uma teoria de determinação de salários, baseada nos diferentes atributos do indivíduo. (Medeiros, 1982)

A expressão Capital Humano tem sido utilizada, em teoria econômica, de forma sistemática e com o objetivo de afetar a política econômica a partir da década de sessenta. A justaposição dos termos "capital" e "humano" tem a intenção de simplesmente caracterizar os atributos do ser humano, caracterizando as qualificações da mão-de-obra. Os estudos nessa área defendem que a escolaridade (educação formal) é uma das principais fontes das desigualdades de ganhos dos indivíduos nas sociedades modernas (Medeiros, op. cit.). 
A teoria do Capital humano foi o primeiro enfoque teórico da importância econômica da educação. Este enfoque foi desenvolvido diretamente a partir da abordagem residual. A idéia inicial foi a de que se educação está associada a crescimento do produto, então os gastos em educação podem ser assemelhados. A característica básica do dispêndio em investimento é a de que permite aumentar o produto futuro da economia. O dispêndio em investimento representa uma posposição do consumo. É nesse sentido, que se afirma que o dispêndio educacional representa uma forma de investimento e, portanto, a teoria do capital humano pode ser aplicada para análise do dispêndio em educação. (Campino, 1986). A idéia fundamental do capital humano é tratar os recursos humanos como uma forma de capital, como o resultado deliberado de uma decisão de investimento (Medeiros, op. cit.)

Schultz (1973), afirma que sempre que a instrução elevar as futuras rendas dos estudantes, teremos um investimento. $\dot{E}$ um investimento no capital humano, sob a forma de habilidades adquiridas na escola. A capacidade produtiva do trabalho é, predominantemente, um meio de produção produzido. Nós produzimos, assim, a nós mesmos e, neste sentido, os recursos humanos são uma consequência de investimentos. A idéia fundamental do capital humano é tratar os recursos humanos como uma forma de capital, como o resultado deliberado de uma decisão de investimento. Assim, Schultz refuta a noção tradicional de trabalho, na qual este era definido como a capacidade de executar tarefa manual, exigindo pouco conhecimento e habilidade específica. A análise que Fonseca (op.cit.) faz sobre Marshall reforça a posição de Schultz. Ele cita Marx que prognosticara no Capital que “ dentro do sistema capitalista (...) todos os meios para desenvolver a produção sofrem uma inversão dialética de modo que redundam em meios de dominar e 
explorar o produtor, mutilam o trabalhador, reduzindo-o a um fragmento de ser humano, degradam-no à categoria de peça de máquina, destroem o conteúdo de seu trabalho transformando (e) tornando-lhe estranhas as potências intelectuais do processo de trabalho na medida em que este se incorpora a ciência como força independente" e conclui que a previsão de Marshall era exatamente o contrário da feita por Marx: Com o avanço tecnológico, o trabalho mecânico e não qualificado tenderia a ser expulso do processo produtivo e a desaparecer. Ao mesmo tempo, cresceria a demanda por capital humano, por trabalhadores qualificados.

Até aqui, a revisão de literatura mencionou o investimento no capital humano em educação. A mesma correlação pode ser feita no que se refere à alimentação, se inferirmos que o investimento em alimentação poderá ocasionar um aumento da capacidade produtiva do trabalho.

Essa correlação pode ser confirmada por Medeiros (op. Cit), quando cita as cinco categorias de investimento em capital humano de Schultz: cuidados médicos, alimentação e habitação, treinamento no trabalho, educação formal, programas de estudos para adultos e migração do indivíduo e família para se ajustarem às alteraç̃es nas oportunidades de emprego.

Como pôde-se observar na revisão de literatura sobre Qualidade de Vida no trabalho, os programas de QVT demonstram uma preocupação em realizar açðes que têm como objetivo a melhoria do bem-estar dos trabalhadores que acaba refletindo no aumento de produtividade para a organização. Essas ações podem ser consideradas, na sua maioria, investimentos em Capital Humano, exatamente como está sendo definido neste capítulo. 
É interessante citar aqui, uma outra discussão referente à dificuldade de mensuraçăo dos efeitos dos diversos investimentos em capital humano. Schultz (in Medeiros, op. Cit.) admite que "à exceção da educaçăo, pouca coisa adequada se conhece a respeito dos outros investimentos em capital humano". No que se refere à escolaridade, os incrementos de ganhos dos indivíduos são proporcionais ao tempo despendido na escola. Becker (op. Cit.) em sua análise sobre capital humano com especial referência à educação, vai além dos incentivos monetários que o conceito implica. Ele cita que vários estudos mostram que a educação promove saúde, reduz o hábito de fumar, aumenta a propensão a voto, dissemina o conhecimento do controle da natalidade e estimula a apreciação da música clássica e literatura.

O atual trabalho tentará avaliar o impacto do investimento em capital humano realizado pelas empresas pesquisadas, através da análise dos índices de absenteísmo e rotatividade, no período anterior e posterior ao Programa de Qualidade de Vida no Trabalho. 
Parte 2

Metodologia e Análise dos Resultados 


\section{1 - OBJETIVO DA PESQUISA}

Analisar as açð̌es dos programas de Qualidade de Vida no Trabalho, os instrumentos de avaliaçð̃es utilizados e a apuração do impacto causado na produtividade, com especial atenção naquelas relacionadas com a alimentação e nutrição dos empregados das organizaçðes.

\section{2 - PROBLEMAS DE PESQUISA:}

- Os Programas de Qualidade de Vida no Trabalho estão desenvolvendo açð̃es de orientação dos hábitos alimentares de seus funcionários, promovendo a saúde e diminuindo a incidência de doenças relacionadas a uma dieta inadequada, especificamente as relacionadas à obesidade, como as doenças coronarianas,?

- Essas ações estão tendo resultados positivos, ou dentro do esperado, pelos Programas de Qualidade de Vida no Trabalho?

- Os investimentos no Capital Humano, como resultados destes Programas de Qualidade de Vida no Trabalho são positivos e atendem os objetivos propostos , uma vez que reduz os gastos com absenteísmo e rotatividade e indicam uma vantagem econômica para as empresas que os adotaram? 


\section{3 - HIPÓTESES DE PESQUISA:}

- Os Programas de Qualidade de Vida no Trabalho, destacados com a premiação como os melhores do ano concedida pela Associação Brasileira de Qualidade de Vida no Trabalho - ABQV, desenvolvem atividades de orientação da dieta alimentar dos seus funcionários, porém não têm indicadores da eficácia do programa e conseqüente mudança de hábitos alimentares.

- Não há uma correlação significativamente positiva entre as ações dos programas da QVT e os indicadores de ocorrência de doenças relacionadas a uma alimentação inadequada, especificamente as relacionadas à obesidade, como as doenças coronarianas.

- Há uma correlação positiva entre as açð̃es de QVT e a retenção dos empregados na organização.

\section{4 - METODOLOGIA DA PESQUISA:}

A pesquisa proposta, por se determinar a abordar uma realidade pouco conhecida, para a qual os dados quantitativos são escassos e as variáveis observadas são de dificil mensuração, deverá utilizar a pesquisa exploratória como meio de investigação. O caráter exploratório e pouco quantificável do objeto de pesquisa indica a necessidade de se utilizar metodologias diversificadas, com especial ênfase para as técnicas qualitativas (Calder, 1977). As pesquisas exploratórias têm como objetivo proporcionar maior familiaridade com o problema, com vistas a torná-lo mais explícito ou a construir hipóteses (Gil, 1946, in Fischer, 1998). Para Selltiz et 
al. (1965), os estudos exploratórios têm o propósito de formular um problema para investigação mais exata, ou desenvolver hipóteses. Podem ser classificados em levantamento de literatura, levantamento das experiências e análise de exemplos. Duas questões deverão ser respondidas pela pesquisa. São elas:

1. Os Programas de Qualidade de Vida no Trabalho estão desenvolvendo ações de orientação dos hábitos alimentares de seus funcionários, promovendo a saúde e diminuindo a incidência de doenças relacionadas a uma dieta inadequada, especificamente as relacionadas à obesidade, como as doenças coronarianas?

2. Essas ações estão tendo resultados positivos, ou dentro do esperado, pelos Programas de Qualidade de Vida no Trabalho?

Lawler III (in Limongi, op.cit), relata a dificuldade em mensurar Qualidade de Vida no Trabalho, devido aos problemas de subjetividade, meio ambiente do trabalho e interesses que diferem em cada grupo. As medidas citadas como objetivas são rotatividade e absenteísmo, além dos índices econômicos utilizados pelo governo.

No atual trabalho, foram pesquisados os índices de absenteísmo e rotatividade, na tentativa de se estabelecer uma correlação entre os Programas de QVT e Produtividade.

\subsubsection{Plano Amostral}

Os levantamentos, de uma maneira geral, abrangem um universo de elementos tão grande que se torna impossível considerá-los em sua totalidade. Por essa razão, costuma-se trabalhar com uma amostra, ou seja, uma pequena parte dos elementos que compð̃em o universo (Gil, op.cit.). Para este projeto, definiu-se uma Amostra 
não-probabilística Intencional. Trata-se de uma amostra não probabilística, uma vez que não há condições de se calcular a probabilidade de seleção de cada unidade da população e os resultados não poderão ser generalizados. Ela é intencional, pois está sendo definida por um critério subjetivo do pesquisador.

Para a realização dos estudos de caso, definiu-se como população as empresas destacadas com o prêmio anual da Associação Brasileira de Qualidade de Vida no Trabalho - ABQV.

O Prêmio Nacional de Qualidade de Vida da ABQV Nacional tem por objetivo estimular o desenvolvimento e a implantação de programas de qualidade de vida nas instituiçð̃es, premiando organizações que realizam açðes específicas e inovadoras neste âmbito de atuação e que tenham êxito na melhoria da qualidade de vida de seus colaboradores.

Pode-se candidatar ao Prêmio Nacional de Qualidade de Vida instituiçðees sediadas em território brasileiro, independentemente de seu porte, número de colaboradores e faturamento, contanto que o Programa de Qualidade de Vida, que está concorrendo ao prêmio, tenha sido implantado no mínimo há dois anos e esteja vigente. $O$ programa é avaliado por uma comissão, que observou o desenvolvimento, implantação e operacionalização nas instituições, através da análise do relatório entregue pela empresa concorrente ao prêmio e de visita ao local, que tem por objetivo a verificação das informações prestadas no Relatório de Avaliação, o esclarecimento de eventuais dúvidas surgidas durante o processo de avaliação, análise e a percepção dos resultados alcançados e nível de satisfação dos colaboradores com relação ao Programa ou Ação específica em questão. 
Esse prêmio existe desde 1995 e já foi concedido a 23 empresas, desde então. São elas:

Vencedores 2001: ABIN - Agência Brasileira de Inteligência

ASBACE/ATP - Associação Brasileira de Bancos Estaduais e Regionais - Distrito Federal

EMBRATEL

SERASA

Usina da Barra

WEG Motores

Vencedores 2000: ABB Ltda.

Givaudan do Brasil Ltda.

Nestlé Brasil Ltda

PISA - Papel de Imprensa S/A

Companhia Imobiliária De Brasília - TERRACAP

Vencedores 1999 : Abril S/A

ALCOA Alumínio

ASEA Brown Boveri

Bank Boston

Cia. Paulista Trens Metropolitanos

Prefeitura Municipal de Curitiba

Siemens

Tribunal Regional Federal - $3^{\mathrm{a}}$ Região

WEG Motores

Vencedores 1998: Bank Boston

Cond. Edif. Conjunto Nacional / MTB Assess.Organizacional Indústrias Gessy Lever - Div. Elida Gibbs 
Vencedores 1997: Banco Sudameris Brasil

Dupont do Brasil - Prêmio Especial

Philips do Brasil - Divisão Walita

Vencedor 1996: Dow Química

A escolha destas empresas para análise e estudo baseou-se no pressuposto que elas já passaram por uma avaliação e que foram selecionadas, dentre outras empresas que também possuem Programas de Qualidade de Vida no Trabalho, por terem destacada atuação na área de QVT.

\subsubsection{Elaboracão do questionário e coleta de dados}

O questionário realizado teve como objetivo obter informaçðes qualitativas sobre os programas de QVT das empresas. Como pode ser apreciado nos anexos 01 e 02 , onde encontram-se a carta-convite e o Modelo do questionário utilizado, todas as questões são abertas e visam apurar os dados sobre a empresa, sobre o programa de QVT, sobre a alimentação e nutrição dentro dos programas de QVT e, por último, sobre as outras açð̃es de QVT.

Foi realizado o pré-teste do instrumento de coleta de dados, com o encaminhamento dos questionários, a $13 \%$ da amostra, ou seja, três empresas.

Duas empresas devolveram o questionário respondido e uma (33\%) não respondeu, apesar dos insistentes contatos.

Com base nas respostas dos pesquisados, algumas alteraçðes foram feitas no instrumento com objetivo de deixar mais clara a intenção da pergunta e ampliar as informaçðes coletadas.

Os questionários foram encaminhados através dos recursos da Internet e as dúvidas foram esclarecidas em contatos telefônicos. 


\section{5 - ANÁLISE DOS RESULTADOS}

Foram contatadas e convidadas para participarem da pesquisa as 23 empresas de todo Brasil, ganhadoras do prêmio anual da ABQV - Associação Brasileira de Qualidade de Vida no Trabalho, dos anos de 1996 a 2001. Dessa amostra, 11 (48\%) não responderam, 02 (9\%) desativaram os programas de Qualidade de Vida no Trabalho e $10(43 \%)$ participaram da pesquisa, uma taxa de retorno que pode ser considerada alta, uma vez que a participação era voluntária.

O painel da pesquisa ficou constituído pelas seguintes empresas:

- BankBoston S/A

- CPTM - Companhia Paulista de Trens Metropolitanos

- Dow Química S/A

- Editora Abril

- EMBRATEL

- Givaudan do Brasil Ltda

- Nestlé Brasil Ltda

- SERASA S/A

- Tribunal Regional Federal $3^{a}$ Região

- WEG Indústrias Ltda

Por se tratar de uma pesquisa qualitativa, os resultados apurados não tiveram tratamento estatístico. 


\subsubsection{Caracterizacão das empresas pesquisadas}

As empresas foram classificadas por ramo de atividade: cinqüenta por cento (50\%) atuam na área de prestação de serviços, quarenta por cento (40\%) na área de indústria e dez por cento (10\%) na área governamental.

\section{Gráfico 1 - Atividade de Empresa}

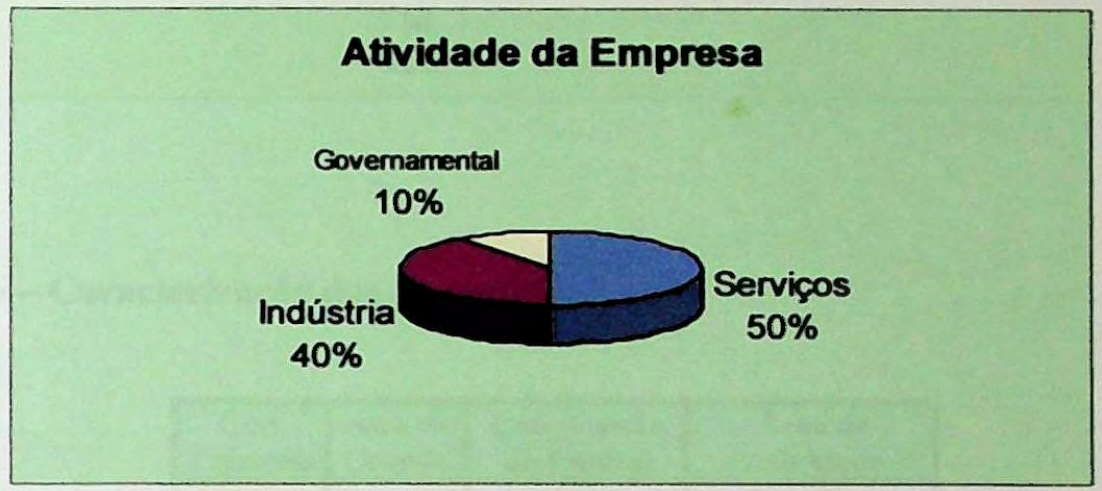

O ano de início de atividades dessas empresas variou de 1784 a 1996 e a origem e composição do capital está dividida em: Capital Nacional (50\%), Capital Internacional (20\%), Capital Misto (10\%). Duas empresas (20\%) não puderam disponibilizar esses dados.

\section{Gráfico 2 - Ano de Criação da Empresa}

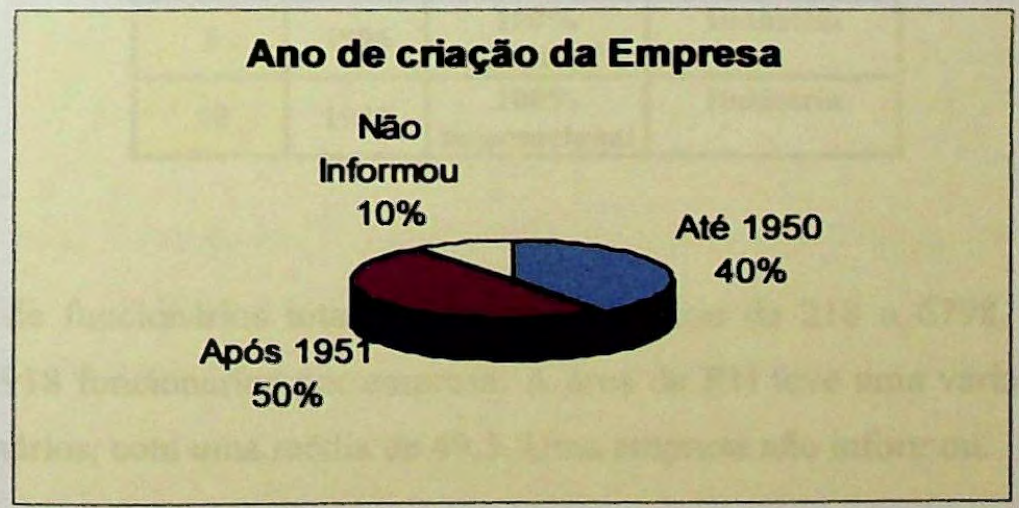




\section{Gráfico 3 - Origem do Capital}

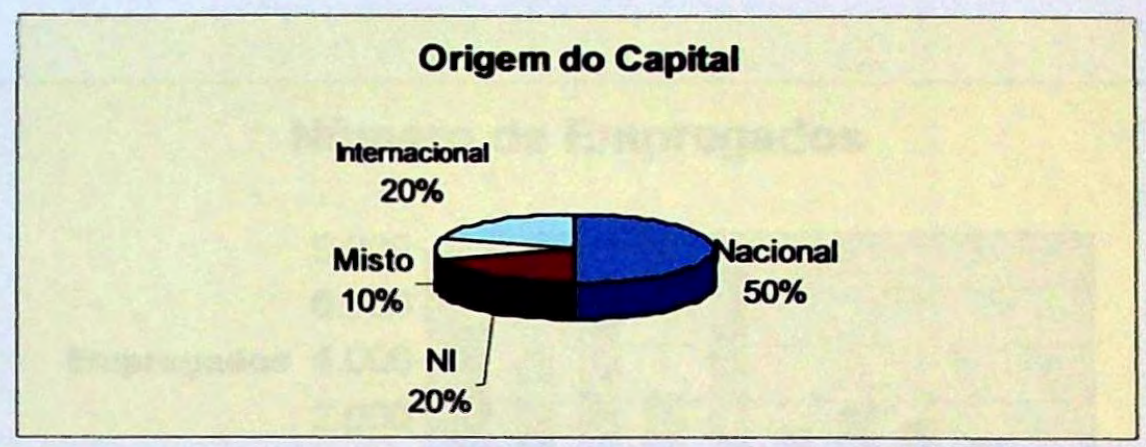

Tabela 6 - Caracterização das Empresas

\begin{tabular}{|c|c|c|c|}
\hline $\begin{array}{c}\text { Cód. } \\
\text { Empresa }\end{array}$ & \begin{tabular}{|l|} 
Ano de \\
Criação
\end{tabular} & $\begin{array}{c}\text { Composição } \\
\text { do Capital }\end{array}$ & $\begin{array}{c}\text { Área de } \\
\text { Atividade }\end{array}$ \\
\hline 1 & 1950 & $\begin{array}{c}100 \% \\
\text { nacional }\end{array}$ & Serviços \\
\hline 2 & 1784 & N.I. & Serviços \\
\hline 3 & 1995 & $\begin{array}{c}100 \% \\
\text { nacional } \\
\end{array}$ & Serviços \\
\hline 4 & NI & \begin{tabular}{c|c|}
$100 \%$ \\
Internacional \\
\end{tabular} & Indústria \\
\hline 5 & 1965 & $\begin{array}{c}81 \% \% \\
\text { Nacional / } \\
19 \text { \% } \% \\
\text { Internacional }\end{array}$ & Serviços \\
\hline 6 & 1867 & ND. & Indústria \\
\hline 7 & 1968 & $\begin{array}{c}100 \% \\
\text { nacional } \\
\end{array}$ & Serviços \\
\hline 8 & 1989 & $\begin{array}{c}100 \% \\
\text { Nacional } \\
\end{array}$ & Governamental \\
\hline 9 & 1996 & $\begin{array}{c}100 \% \\
\text { Nacional }\end{array}$ & Indústria \\
\hline 10 & 1949 & \begin{tabular}{c|c|}
$100 \%$ \\
Internacional
\end{tabular} & Indústria \\
\hline
\end{tabular}

O número de funcionários total das empresas variou de 218 a 6798 , dando uma média de 2918 funcionários por empresa. A área de RH teve uma variação de 07 a 100 funcionários, com uma média de 49,5. Uma empresa não informou. 
Gráfico 4 - Número de Empregados das Empresas Pesquisadas

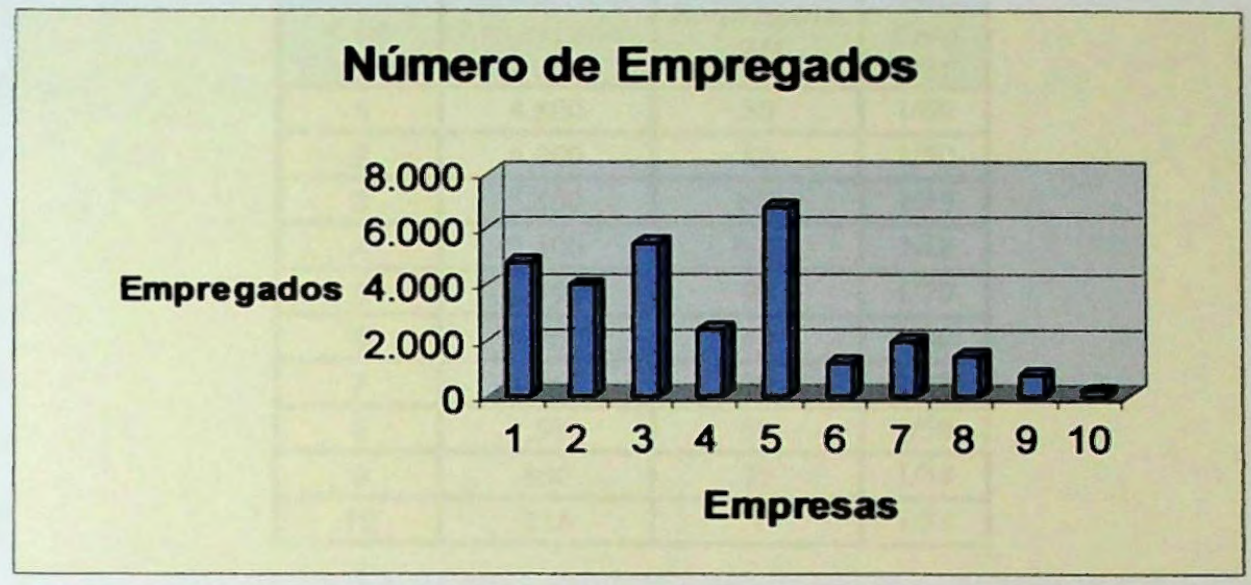

Gráfico 5 - Número de Empregados de RH das Empresas Pesquisadas

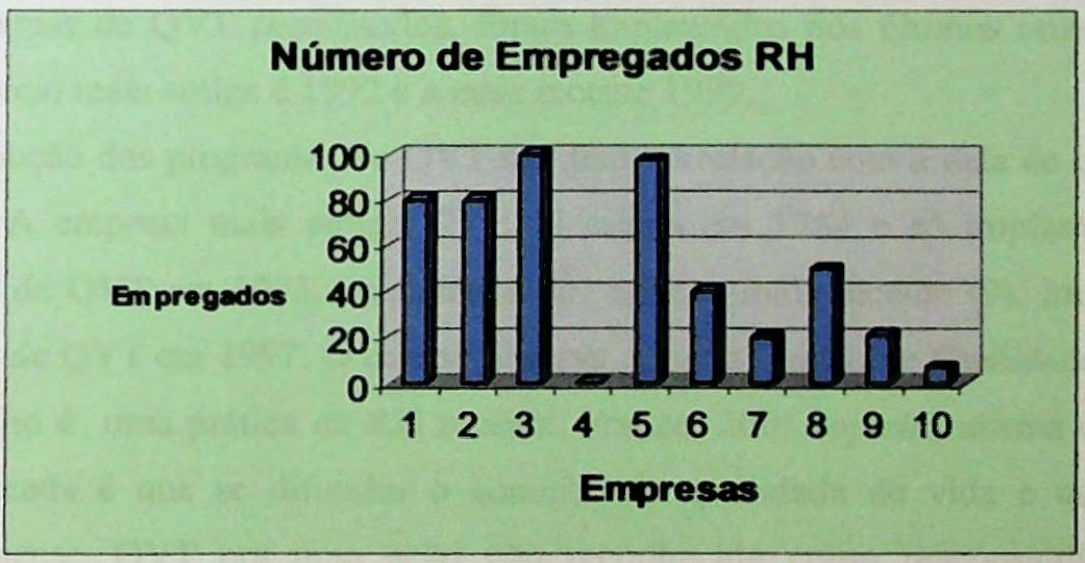

Com os dados levantados, pôde-se concluir que, em média, nas empresas pesquisadas há 59 empregados para cada profissional de RH. Abaixo, apresentamos a relação média de empregados por funcionário de RH, por empresa pesquisada: 
Tabela 7 - Número de Empregados para cada profissional de RH

\begin{tabular}{|c|c|c|c|}
\hline $\begin{array}{c}\text { Cód. } \\
\text { Empresa }\end{array}$ & $\begin{array}{c}\mathbf{N}^{\circ} \\
\text { Empregados. }\end{array}$ & $\begin{array}{c}\mathbf{N}^{\circ} \\
\text { Empregados } \\
\mathbf{R H}\end{array}$ & $\begin{array}{c}\mathbf{N}^{\circ} \\
\text { Emp/ } \\
\text { Emp } \\
\mathbf{R H}\end{array}$ \\
\hline 1 & 4.800 & 80 & $1 / 60$ \\
\hline 2 & 4.000 & 80 & $1 / 50$ \\
\hline 3 & 5.500 & 100 & $1 / 55$ \\
\hline 4 & 2.400 & N.I. & ND \\
\hline 5 & 6.798 & 97 & $1 / 70$ \\
\hline 6 & 1.200 & 40 & $1 / 30$ \\
\hline 7 & 1.966 & 20 & $1 / 98$ \\
\hline 8 & 1.500 & 50 & $1 / 50$ \\
\hline 9 & 800 & 21 & $1 / 38$ \\
\hline 10 & 218 & 7 & $1 / 31$ \\
\hline
\end{tabular}

\subsection{2 - Os programas de qualidade de vida no trabalho}

Os programas de QVT pesquisados, foram implantados nos últimos onze anos. A data de início mais antiga é 1992 e a mais recente 1999.

A implantação dos programas de QVT não tem correlação com a data de criação da empresa. A empresa mais antiga (2) , foi criada em 1784 e só implantou o seu programa de QVT em 1993, enquanto a de criação mais recente (9), implantou o programa de QVT em 1997. O que se observa é que a Gestão de Qualidade de Vida no Trabalho é uma prática de RH recente. França, 2001 (op.cit.) afirma que só na última década é que se difundiu o conceito de qualidade de vida e que, muito provavelmente, QVT era uma ação não reconhecida como responsabilidade do ambiente interno da organização, tanto por empregadores como por empregados.

A constatação de uma prática recente também pode ser confirmada pelos dados da Pesquisa RH-2010, já citada, que mostra que apenas $32 \%$ das empresas pesquisadas já implantaram a gestão de QVT, apesar de a considerarem muito importante.

A maioria dos programas de QVT pesquisados foi desenvolvida de acordo com as necessidades da unidade local da empresa (60\%); Vinte por cento (20\%) desenvolveu 
o seu programa de QVT localmente, porém seguindo os padrões da matriz da organização e vinte por cento (20\%) não informaram.

\section{Gráfico 6 - Padrões para o desenvolvimento do Programa de QVT}

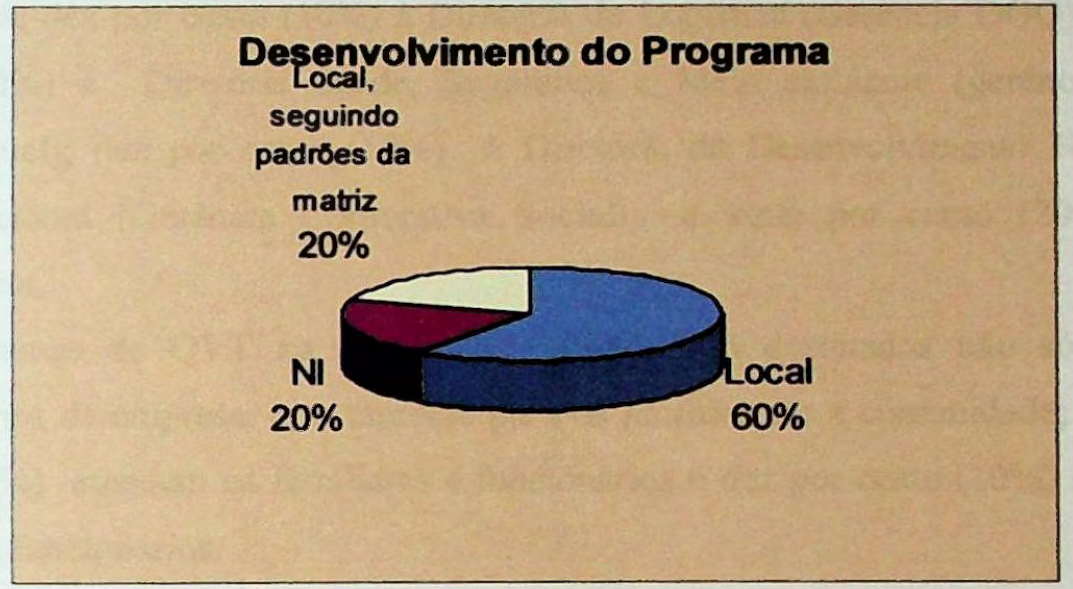

Tabela 8 - Ano de criação do Programa de QVT e padrões para o desenvolvimento do programa

\begin{tabular}{|c|c|c|}
\hline $\begin{array}{c}\text { Cód. } \\
\text { Empresa }\end{array}$ & $\begin{array}{c}\text { Ano de } \\
\text { Criação } \\
\text { PQVT }\end{array}$ & $\begin{array}{c}\text { Desenvolvimento } \\
\text { do Programa }\end{array}$ \\
\hline 1 & 1993 & Local \\
\hline 2 & 1995 & $\begin{array}{c}\text { Local, com os } \\
\text { padrões da matriz }\end{array}$ \\
\hline 3 & 1995 & Local \\
\hline 4 & 1992 & Local \\
\hline 5 & 1999 & NI \\
\hline 6 & 1998 & Local \\
\hline 7 & 1999 & Local \\
\hline 8 & 1998 & Local \\
\hline 9 & 1997 & $\begin{array}{c}\text { Localmente, } \\
\text { seguindo modelo } \\
\text { da matriz (SC) }\end{array}$ \\
\hline 10 & 1998 & NI \\
\hline
\end{tabular}


Os Programas de QVT estão inseridos na hierarquia da organização de maneira bastante variada:

Vinte por cento $(20 \%)$ reportam-se diretamente à presidência; vinte por cento (20\%) à Diretoria RH -(Gerência RH - 10\% e Gerência Saúde e bem estar 10\%); Dez por cento $(10 \%)$ à Diretoria Administrativa; Dez por cento $(10 \%)$ à Diretoria de Benefícios, dez por cento (10\%) à Diretoria de Logística (Gerência DGQ); dez por cento $(10 \%)$ à Diretoria Saúde, Segurança e Meio ambiente (gerência Saúde Ocupacional); dez por cento $(10 \%)$ à Diretoria de Desenvolvimento Humano e Organizacional (Gerência Corporativa Social) e vinte por cento $(20 \%)$ não informaram.

Os programas de QVT na sua maioria (80\%) são destinados não só para os funcionários da empresa, mas também para os familiares e a comunidade; vinte por cento $(20 \%)$ atendem os familiares e funcionários e dez por cento $(10 \%)$ abrangem apenas os funcionários.

\section{Gráfico 7 - Abrangência do Programa de QVT}

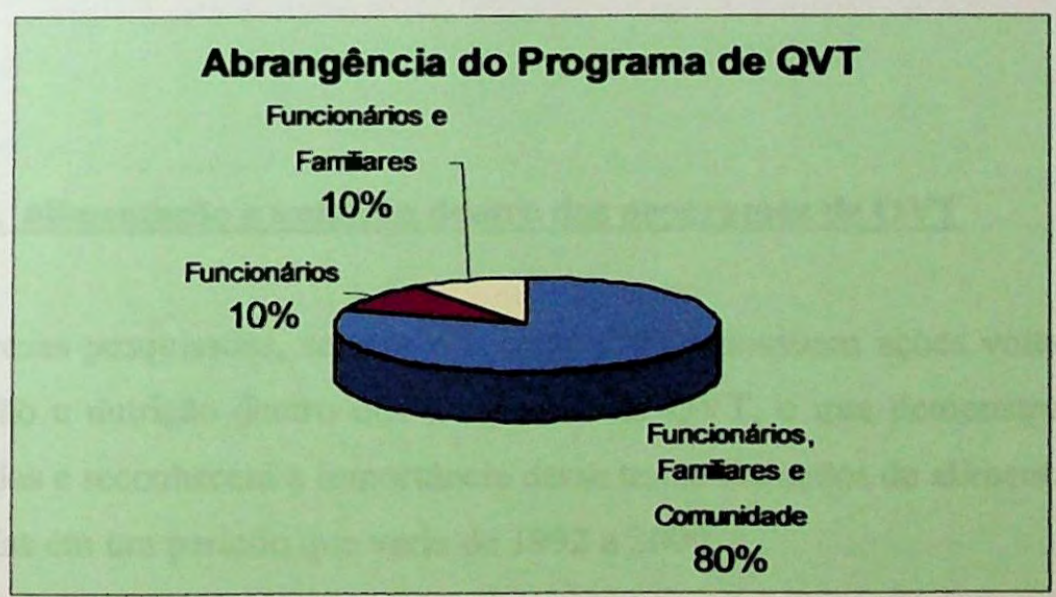


Tabela 9 - Reporte hierárquico e Abrangência do Programa de QVT

\begin{tabular}{|c|c|c|}
\hline $\begin{array}{c}\text { Cód. } \\
\text { Empresa }\end{array}$ & $\begin{array}{c}\text { Reporte } \\
\text { Hierárquico }\end{array}$ & $\begin{array}{c}\text { Abrangência do } \\
\text { Programa }\end{array}$ \\
\hline 1 & $\begin{array}{l}\text { Diretoria } \\
\text { Administrativa } \\
\end{array}$ & $\begin{array}{l}\text { Funcionários, familiares e } \\
\text { comunidade. }\end{array}$ \\
\hline 2 & \begin{tabular}{|l|} 
Diretoria de \\
Beneficios \\
\end{tabular} & $\begin{array}{l}\text { Funcionários, familiares, } \\
\text { comunidade. }\end{array}$ \\
\hline 3 & $\begin{array}{l}\text { Presidência da } \\
\text { Empresa. }\end{array}$ & $\begin{array}{l}\text { Funcionários, familiares } \\
\text { e a comunidade }\end{array}$ \\
\hline 4 & $\begin{array}{l}\text { Depto de Saúde, } \\
\text { Segurança e } \\
\text { Meio Ambiente. } \\
\end{array}$ & $\begin{array}{l}\text { Funcionários, familiares e } \\
\text { comunidade.. }\end{array}$ \\
\hline 5 & $\begin{array}{l}\text { Diretoria de } \\
\text { Recursos } \\
\text { Humanos } \\
\end{array}$ & $\begin{array}{l}\text { Funcionários, familiares e } \\
\text { comunidade. }\end{array}$ \\
\hline 6 & $\begin{array}{l}\text { Divisão de } \\
\text { Recursos } \\
\text { Humanos } \\
\end{array}$ & $\begin{array}{l}\text { Colaboradores e } \\
\text { familiares }\end{array}$ \\
\hline 7 & \begin{tabular}{|l|} 
Diretoria de \\
Desenvolvimento \\
Humano e \\
Organizacional \\
\end{tabular} & $\begin{array}{l}\text { Funcionários, familiares, } \\
\text { comunidade }\end{array}$ \\
\hline 8 & Presidência & Funcionário \\
\hline 9 & $\begin{array}{l}\text { Diretor de } \\
\text { logística }\end{array}$ & $\begin{array}{l}\text { Funcionários, familiares e } \\
\text { comunidade. }\end{array}$ \\
\hline 10 & NI & $\begin{array}{l}\text { Funcionários, familiares, } \\
\text { comunidade }\end{array}$ \\
\hline
\end{tabular}

\subsection{3 - A alimentacão e nutricão dentro dos proqramas de OVT}

Das empresas pesquisadas, setenta por cento $(70 \%)$ possuem ações voltadas para a alimentação e nutrição dentro dos programas de QVT, o que demonstra que estão preocupadas e reconhecem a importância desse tema. As ações de alimentação foram implantadas em um período que varia de 1992 a 2000. 
Gráfico 8 - Empresas que contemplam a Alimentação e Nutrição nos programas de QVT

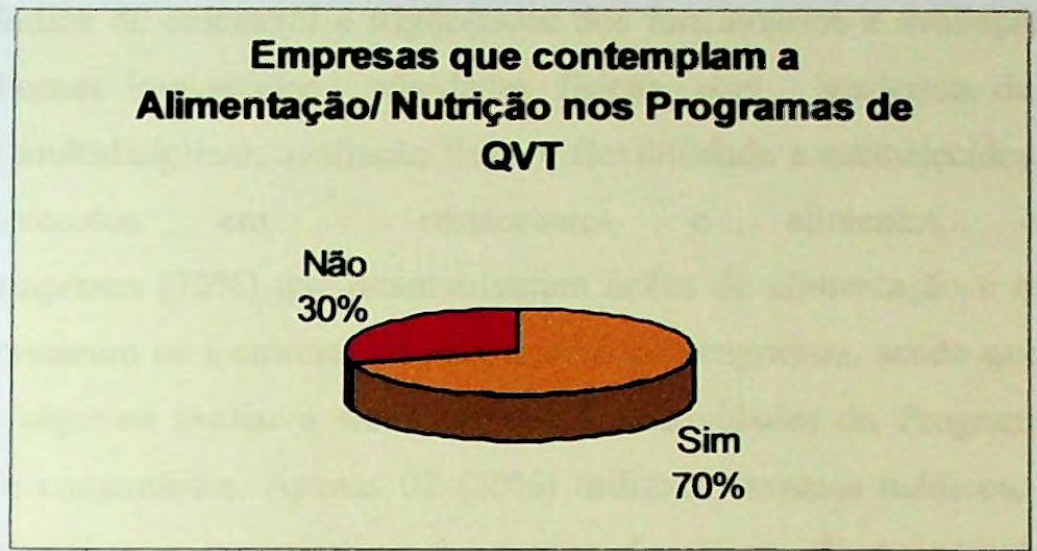

Gráfico 9 - Ano de Implantação da ação de alimentação nos programas de QVT

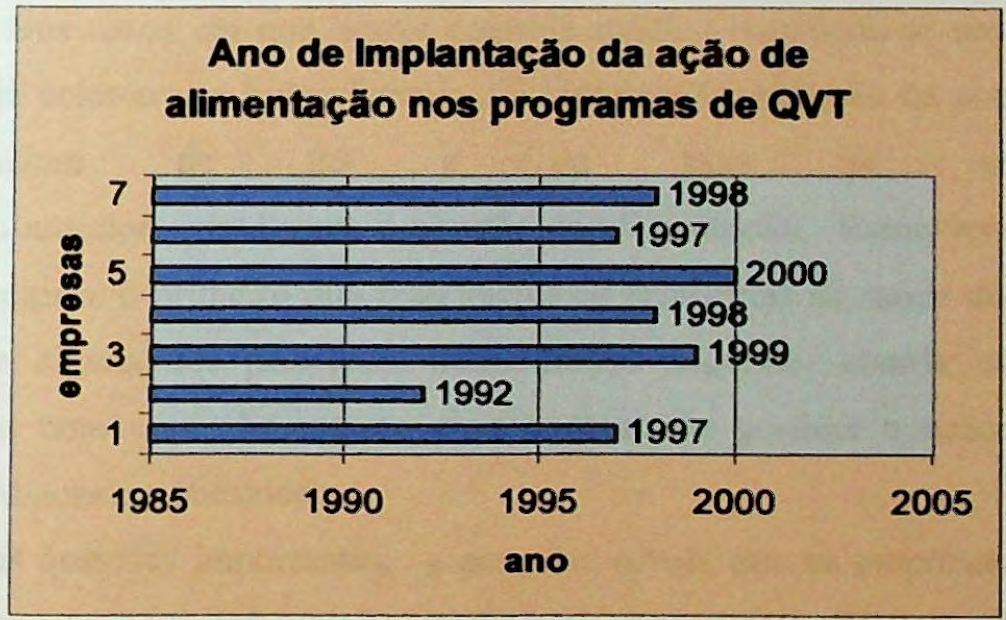

Os programas desenvolvidos tiveram como objetivo a reeducação dos hábitos alimentares e gerenciamento do peso dos empregados, através de acompanhamento médico e credenciamento de nutricionistas para orientação nutricional, implantação do programa dos "Vigilantes do Peso" na empresa, realização de palestras e confeç̧ão de informativos sobre prevenção de doenças e nutrição, disponibilização de receitas hipocalóricas via intranet, introdução no cardápio da empresa de refeições saudáveis e balanceadas, com alimentação hipossódica, hipocalórica, doces dietéticos 
e contagem calórica dos alimentos. Além disso, foi reportada a realização de reuniōes mensais sobre o cardápio da empresa; a realização do levantamento do IMC, do índice de colesterol e triglicérides dos funcionários e avaliação da dobra cutânea. Foram implantadas atividades físicas, com academia de ginástica, orientação multidiciplinar, avaliação física e flexibilidade e estabelecidos convênios com descontos em restaurantes e alimentos congelados. Das sete empresas (70\%) que desenvolveram açðes de alimentação e nutrição, 05 (50\%) informaram os instrumentos para avaliar os programas, sendo que $03(30 \%)$ têm como objetivo avaliar a satisfação com as atividades do Programa e obter sugestões e comentários. Apenas $02(20 \%)$ utilizam exames médicos, sendo que uma delas realiza o comparativo de grupos de riscos, de colesterol, glicemia, triglicérides, além do levantamento do IMC e índice de Sedentarismo. Os resultados obtidos foram avaliados na sua totalidade como positivos, com a obtenção de conscientização crescente dos funcionários e, em alguns casos, também dos familiares. Nos casos em que houve controle médico, verificou-se um decréscimo nas taxas de colesterol e hiperglicemia, da hipertensão, redução da população com IMC acima de 26 e da taxa de sedentarismo. No capítulo anterior, que discute a questão da alimentação, foram levantados dois pontos principais: o primeiro que relacionava os problemas de saúde decorrentes da carência de alguns dos principais nutrientes; o segundo, aborda os problemas relacionados com uma alimentação com excesso de gordura e açúcar, como as doenças cardíacas e a obesidade.

Dessas duas questões importantes, a pesquisa revela que as empresas da amostra estão preocupadas com deficiências nutricionais decorrentes do consumo alimentar excessivo, característico das populações dos grandes centros urbanos, em que se encontra incluída a nossa amostra, confirmando a análise da nutrição e do desenvolvimento econômico de Muller (op. cit.), já mencionada neste trabalho. 


\subsection{4-As outras acões dos proqramas de QVT}

As ações realizadas pelas empresas pesquisadas, foram classificadas de acordo com os critérios do modelo BPSO-96, já mencionado anteriormente, desenvolvido por França, 2001 (op.cit) em que se analisa as variáveis de acordo com a sua natureza: biológica, psicológica, social e organizacional.

As ações desenvolvidas, foram classificadas na sua maioria (61\%), como sendo de natureza biológica. Elas estão voltadas para a saúde e bem-estar do empregado, realizando ações para prevenção de doenças, com a realização de exames médicos e laboratoriais periódicos, campanhas de vacinação, orientação à gestantes, implantação de atividades fisicas, como academia de ginástica, ginástica laboral, alongamento, shiatsu, Lian Gong, prática de esportes; Contratação de profissionais como fonoaudiólogos e fisioterapeutas para realização de RPG; Programas de ergonomia; campanhas informativas sobre Doenças sexualmente transmissiveis, drogas, fumo e álcool; Programas de diagnóstico e prevenção de doenças coronárias, de pele e estomacais.

As ações de natureza Psicológica representam $8 \%$ do total apurado na pesquisa e estão relacionadas ao gerenciamento do estresse, disponibilização de psicoterapia $e$ de terapêuticas preventivas e de aprimoramento pessoal.

As ações de natureza Social ocupam um espaço um pouco maior: 16\%. Elas se concentram em atividades de lazer (Parcerias com os parques de diversão da cidade, ingressos de cinema, vídeo locadora, tomeios e festividades), com envolvimento da família; e de cultura (Oficinas, concertos, promoçðes, espetáculos fechados, livros palestras, coral, concurso de fotografia etc).

A última classificação, a Organizacional, representou $15 \%$ das ações informadas na pesquisa. São açס̃es voltadas para o exercício da cidadania, que projetam uma imagem externa da empresa positiva (grupos ecológicos, orientação de grafiteiros, trabalhos voluntários, coleta seletiva e reciclagem de lixo, adoção de uma escola) e de valorização da imagem interna da empresa (endomarketing), com informativos, palestras e site do programa.

Essas ações, estão relacionadas ao fator crítico Práticas e Valores da Empresa de acordo com o modelo conceitual de França (2003, op. cit). Pode-se perceber que 
estas novas práticas organizacionais estão presentes e de maneira bastante diversificada.

A seguir, a tabulação dos dados apurados:

\section{Gráfico 10 - Classificação das ações de QVT}

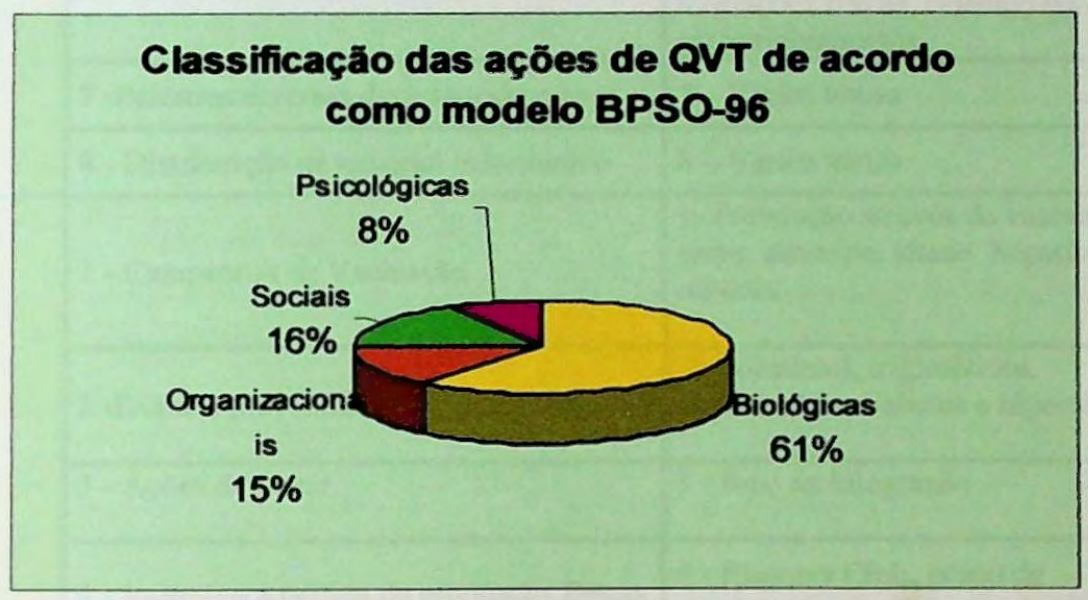

Tabela 10 - Ações de QVT

\begin{tabular}{|c|c|c|c|}
\hline EMPRESAS & AÇÕES & CONTEÚdO & $\begin{array}{l}\text { CLASSIFICA } \\
\text { ÇÃO DA } \\
\text { AÇÃO }\end{array}$ \\
\hline \multirow{5}{*}{01} & 1 - Programa Vida Nova & $\begin{array}{l}1 \text { - Exames médicos periódicos, } \\
\text { avaliações fisicas, orientações e } \\
\text { encaminhamentos }\end{array}$ & B \\
\hline & 2 - Semana Vida Nova & $\begin{array}{l}2 \text { - Semana voltada à informações } \\
\text { sobre saúde e bern estar }\end{array}$ & B \\
\hline & $\begin{array}{l}3 \text { - Diversos programas contínuos voltados } \\
\text { a prevenção de doenças ocupacionais: } \\
\text { Call Center, áreas operacionais, } \\
\text { participação de } 1000 \text { funcionários (início } \\
1998 \text { e 1999); }\end{array}$ & $\begin{array}{l}3 \text { - Utilizada várias técnicas; } \\
\text { ginástica laboral, RPG, Lian Gong } \\
\text {, profissionais fisioterapeutas, } \\
\text { médicos fonoaudiólogos }\end{array}$ & B \\
\hline & $\begin{array}{l}4 \text { - Programa Gestante } 9 \text { encontros por } \\
\text { grupo de gestantes (mais de } 250 \text { mulheres } \\
\text { já passaram pelo programa) }\end{array}$ & $\begin{array}{l}4 \text { - Informações médicas, } \\
\text { alimentação, e reflexões sobre o } \\
\text { estar gestante são conteúdo do } \\
\text { programa }\end{array}$ & B \\
\hline & $\begin{array}{l}5 \text { - Programas coletivos sobre ergonomia } \\
\text { no local de trabalho; }\end{array}$ & $\begin{array}{l}5 \text { - Mais de } 1000 \text { avaliações } \\
\text { individuais e orientaç̋̃es sobre } \\
\text { posto de trabalho e postura física } \\
\text { adequada }\end{array}$ & B \\
\hline
\end{tabular}


Tabela 10 (cont.) - Ações de QVT

\begin{tabular}{|c|c|c|c|}
\hline EMPRESAS & AÇÕES & CONTEÚDOO & $\begin{array}{l}\text { CLASSIFICA } \\
\text { ÇÃO DA } \\
\text { AÇÃO }\end{array}$ \\
\hline \multirow[t]{3}{*}{01} & $\begin{array}{l}\text { 6- Gerenciando o Stress - Programa para } \\
\text { grupo de funcionários; }\end{array}$ & $\begin{array}{l}6 \text { - Informações e encontros com } \\
\text { profissionais para identificação do } \\
\text { stress e alternativas para seu } \\
\text { controle } \\
\text { Exames médicos periódicos, } \\
\text { avaliações fisicas, orientações e } \\
\text { encaminhamentos }\end{array}$ & $\mathbf{P}$ \\
\hline & 7 -Palestras diversas durante todo o ano; & 7 - Vários temas & - \\
\hline & 8 - Distribuição de material informativo & 8 - Vários temas & - \\
\hline \multirow{8}{*}{02} & 1 - Campanhas de Vacinaçăo & $\begin{array}{l}1 \text {-Prevenção através da vacina: } \\
\text { gripe, sarampo, tétano hepatite, } \\
\text { rubéola }\end{array}$ & B \\
\hline & 2 -Exames preventivos & $\begin{array}{l}\text { 2-colesterol, triglicérides, } \\
\text { papanicolau, diabetes e hipertensão }\end{array}$ & B \\
\hline & 3 - Ações de Lazer & 3 - foco na integração & $\mathbf{S}$ \\
\hline & 4 - Incentivo à prática de atividades fisicas & $\begin{array}{l}4 \text { - Runners Club, grupo de } \\
\text { caminhada e corrida, academia, } \\
\text { olimpiada esportiva, torneios etc }\end{array}$ & B \\
\hline & 5 - Facilidades e serviços & $\begin{array}{l}5 \text { - Promoções e serviços que } \\
\text { facilitam o dia-a-dia }\end{array}$ & $\mathbf{S}$ \\
\hline & 6-Família & $\begin{array}{l}6 \text { - Busca o envolvimento em } \\
\text { diversas açoes dentro da empresa }\end{array}$ & $\mathbf{S}$ \\
\hline & 7-Comunidade & $\begin{array}{l}7 \text {-Ações expandidas à } \\
\text { comunidade. Grupo ecológico }\end{array}$ & $\mathbf{O}$ \\
\hline & 8 - Cultura & $\begin{array}{l}8 \text { - Oficinas, concertos, } \\
\text { promoções, espetáculos fechados, } \\
\text { livros palestras, coral etc }\end{array}$ & $\mathbf{S}$ \\
\hline \multirow{4}{*}{$\mathbf{0 3}$} & 1 -Projeto Grafite & $\begin{array}{l}1 \text { - Orientar grafiteiros para ajudar } \\
\text { e não degradar os muros da } \\
\text { empresa }\end{array}$ & O \\
\hline & 2 - Campanhas na comunidade & $\begin{array}{l}\text { 2- Orientar os clientes nos } \\
\text { problemas de álcool, drogas, } \\
\text { AIDS, LER, doação de sangue, etc }\end{array}$ & B \\
\hline & 3 -Olimpiadas & $\begin{array}{l}3 \text { - Estimular os funcionários a } \\
\text { praticarem atividades esportivas }\end{array}$ & B \\
\hline & 4 - Seja um Voluntário & $\begin{array}{l}4 \text { - Estimular em cada funcionário, } \\
\text { a vontade de ajudar que necessita. }\end{array}$ & O \\
\hline
\end{tabular}


Tabela 10 (cont.) - Ações de QVT

\begin{tabular}{|c|c|c|c|}
\hline EMPRESAS & AÇÕES & CONTEÚDO & $\begin{array}{l}\text { CLASSIFICA } \\
\text { Ç̃̃O DA } \\
\text { AÇÃ̃O }\end{array}$ \\
\hline \multirow{10}{*}{04} & 1 - Ginástica laboral & NI & B \\
\hline & 2 - Massagem na empresa & NI & B \\
\hline & 3 -Ginástica na empresa & NI & B \\
\hline & 4 - Palestras educativas & NI & o \\
\hline & $\begin{array}{l}5 \text {-Material educativo diverso e sempre } \\
\text { distribuído }\end{array}$ & NI & o \\
\hline & 6 -Atividades de lazer & $y^{2}$ & $\mathbf{S}$ \\
\hline & 7-Campeonatos de boliche & NI & S \\
\hline & 8 -Seminários vivenciais de stress & NI & $\mathbf{P}$ \\
\hline & 9- Revista do Programa & NI & 0 \\
\hline & $\begin{array}{l}10 \text {-Campanhas de saúde com temas } \\
\text { especificos }\end{array}$ & NI & B \\
\hline \multirow{7}{*}{05} & 1-Condicionamento Físico & $\begin{array}{l}1 \text { - Centros de Condicionamento } \\
\text { Físico com equipamentos e } \\
\text { professores especializados das } \\
6: 45 \text { as } 21: 00 \mathrm{~h}\end{array}$ & B \\
\hline & 2 - Shiatsu & $\begin{array}{l}\text { 2- Realização de sessões de } \\
\text { shiatsu em empregados. }\end{array}$ & B \\
\hline & 3 - Ginástica Laboral & $\begin{array}{l}3 \text { - Realização de ginástica laboral } \\
\text { no início expediente- } \\
\text { setores/localidades }\end{array}$ & B \\
\hline & 4 -Palestras & $\begin{array}{l}\text { 4- Palestras sobre diversos temas } \\
\text { transmitidas para todas as } \\
\text { localidades, via Tv Executiva }\end{array}$ & 0 \\
\hline & 5 -Site do Programa & $\begin{array}{l}5 \text { - Diversas informações e dicas } \\
\text { sobre Qualidade de Vida, } \\
\text { realizadas em diversas localidades, } \\
\text { com os familiares }\end{array}$ & 0 \\
\hline & 6-Caminhadas & - & B \\
\hline & 7-Equipe de Atletismo & $\begin{array}{l}7 \text { - Participação em campeonatos. } \\
\text { Orientação de téc. Especializado. }\end{array}$ & B \\
\hline
\end{tabular}


Tabela 10 (cont.) - Ações de QVT

\begin{tabular}{|c|c|c|c|}
\hline EMPRESAS & AÇÕES & CONTEÚDO & $\begin{array}{l}\text { CLASSIFIC } \\
\text { AÇÃO DA } \\
\text { AÇÃO } \\
\end{array}$ \\
\hline \multirow{9}{*}{06} & $\begin{array}{l}1 \text { - Campanha de Prevenção ao } \\
\text { Cigarro, }\end{array}$ & 1 - Criação de um fumódromo & B \\
\hline & $\begin{array}{l}2 \text { - Campanha de Vacinação contra } \\
\text { a Gripe (anual). }\end{array}$ & $2-\mathrm{NI}$ & B \\
\hline & $\begin{array}{l}3 \text { - Campanha de Prevenção de } \\
\text { Doenças de Pele e Estomacais. }\end{array}$ & $3-\mathrm{NI}$ & B \\
\hline & 4 - Criação do Fitness & 4 - Ginástica Coletiva & B \\
\hline & 6 - Semana da Saúde & $\begin{array}{l}\text { 6- possibilidade dos colaboradores } \\
\text { medirem e acompanharem as taxas de } \\
\text { glicemia, colesterol, checkup biológico, } \\
\text { controle de peso, de pressão, etc. }\end{array}$ & B \\
\hline & 7 - Grupo de corridas & 7 - Parceria com Powerbar & B \\
\hline & 8 - Disque Vídeo & $\begin{array}{l}8 \text { - Implantação de uma vídeo locadora } \\
\text { interna }\end{array}$ & $\mathbf{S}$ \\
\hline & $\begin{array}{l}9 \text { - Parcerias com os parques de } \\
\text { diversão da cidade + ingressos de } \\
\text { cinema (CINEMARK) }\end{array}$ & $9-\mathrm{NI}$ & $\mathbf{S}$ \\
\hline & 10 - Plano Q. & $\begin{array}{l}10 \text { - diversas terapias com especialidades } \\
\text { médicas, psicológicas, terapêuticas } \\
\text { preventivas e de aprimoramento pessoal }\end{array}$ & $\mathbf{P}$ \\
\hline \multirow{10}{*}{07} & $\begin{array}{l}1 \text { - Campanha de Vacinação contra } \\
\text { a Gripe }\end{array}$ & NI & B \\
\hline & 2 - Campanha de Testes Colesterol & NI & B \\
\hline & $\begin{array}{l}3 \text { - Campanha de Testes de } \\
\text { Glicemia }\end{array}$ & NI & B \\
\hline & $\begin{array}{l}4 \text { - Campanha de.Testes de } \\
\text { Acuidade Visual }\end{array}$ & NI & B \\
\hline & 5 - Palestra sobre Antitabagismo & NI & B \\
\hline & 6 - Dia do Desafio & NI & $\mathbf{S}$ \\
\hline & 7 - Fórum de Qualidade de Vida & NI & O \\
\hline & 8 - Programa.Antitabagismo & NI & B \\
\hline & 9- Banco de Talentos: & $\begin{array}{l}\text { Concurso de Fotografia.Coral Canto } \\
\text { Geral.Campeonato de Futsal.Torneio de } \\
\text { Tênis.Torneio de Sinuca.. Jogos }\end{array}$ & $\mathbf{S}$ \\
\hline & 10. Ginástica Laboral & NI & B \\
\hline
\end{tabular}


Tabela 10 (cont.) - Ações de QVT

\begin{tabular}{|c|c|c|c|}
\hline EMPRESAS & AÇŌES & CONTEÚDO & $\begin{array}{l}\text { CLASSIFIC } \\
\text { AÇĀO DA } \\
\text { AÇÃO } \\
\end{array}$ \\
\hline \multirow{4}{*}{08} & 1 - condicionamento fisico & 1 - fitness, ginastica laboral, alongamento & B \\
\hline & 2 - gerenciamento do stress & $\begin{array}{l}2 \text { - gestão em saúde mental, atividades em } \\
\text { grupo, avaliação }\end{array}$ & $\mathbf{P}$ \\
\hline & $\begin{array}{l}3 \text {-doenças } \\
\text { cronicas(HAS,DIABETE,COLEST } \\
\text { EROL, ETC }\end{array}$ & $\begin{array}{l}3 \text { - rastreamento, acompanhamento, } \\
\text { orientação, fornecimento de medicamentos, } \\
\text { educação }\end{array}$ & B \\
\hline & 4 - violência urbana & $\begin{array}{l}4 \text { - orientação, acolhimento, atendimento, } \\
\text { reflexão }\end{array}$ & $\mathbf{P}$ \\
\hline \multirow{5}{*}{09} & 1-Campanhas Médicas & 1- Vacinação, doação de sangue, etc. & B \\
\hline & 2 - Semana da Qualidade de Vida; & 2_Folhetos explicativos; & O \\
\hline & 3 - Ginástica Laboral & $\begin{array}{l}\text { 3- Ginástica compensatória, realizada no } \\
\text { início do expediente; }\end{array}$ & B \\
\hline & 4 - Comitê de ergonomia; & $\begin{array}{l}4 \text { - Reuniões mensais com ações que } \\
\text { adequem o posto de trabalho ao } \\
\text { trabalhador; }\end{array}$ & B \\
\hline & 5 -Academia & 5 - Atividades diárias monitoradas. & B \\
\hline \multirow{6}{*}{10} & 1-Processo de Saúde Ocupacional & $\begin{array}{l}1 \text { - Levantamento estatístico mensal e } \\
\text { avaliação bucal }\end{array}$ & B \\
\hline & $\begin{array}{l}2 \text { - Processo Política Anti- } \\
\text { Tabagismo }\end{array}$ & $\begin{array}{l}\text { 2- Cadastramento dos fumantes; Cartões } \\
\text { de visitantes; Fumódromos; Controle do } \\
\text { Grupo de Fumantes; Campanhas contínuas. }\end{array}$ & B \\
\hline & 3 - Processo Coração Saudável & $\begin{array}{l}\text { 3- Acompanhamento dos grupos de riscos; } \\
\text { Campanha educacional contínua; } \\
\text { Acompanhamento médico Individualizado; } \\
\text { Revisão do perfil de risco cardiaco; Cartilha } \\
\text { da saúde. }\end{array}$ & B \\
\hline & 4- Processo Ginástica Laboral & $\begin{array}{l}\text { 4-Teste de flexibilidade; Monitorização } \\
\text { das dores do corpo;Pesquisas; Destaque do } \\
\text { mês de cada área. }\end{array}$ & B \\
\hline & 5 - Processo Ginástica Empresarial & $\begin{array}{l}\text { 5- Ampliação dos horários; Avaliação } \\
\text { fisica anual; Grupos especiais; Destaque do } \\
\text { mês; Inovações de atividades; Programa } \\
\text { personalizado; Acompanhamento } \\
\text { Multidisciplinar. }\end{array}$ & B \\
\hline & $\begin{array}{l}\text { 6-Processo Administração do } \\
\text { Stress }\end{array}$ & $\begin{array}{l}6 \text { - Vivências; Palestras; Massagem } \\
\text { bioenergética; Psicoterapia. }\end{array}$ & $\mathbf{P}$ \\
\hline
\end{tabular}


Tabela 10 (cont.) - Ações de QVT

\begin{tabular}{|c|c|c|c|}
\hline EMPRESAS & AÇÕES & CONTEÚDO & $\begin{array}{c}\text { CLASSIFICA } \\
\text { ÇÃO DA } \\
\text { AÇĀO }\end{array}$ \\
\hline \multirow{5}{*}{10} & 7-Processo de Ergonomia & $\begin{array}{l}\text { 7- Pesquisa de ergonomia; Laudo } \\
\text { ergonômico; Acompanhamento das } \\
\text { soluções por área; Análise ergonômica dos } \\
\text { postos de trabalho; Comitê de ergonomia; } \\
\text { Escola da coluna - RPG. }\end{array}$ & B \\
\hline & $\begin{array}{l}8 \text { - Processo de Coleta seletiva e } \\
\text { reciclagem }\end{array}$ & $\begin{array}{l}8 \text { - Plantio de árvore pelo presidente; } \\
\text { Distribuição de muda de planta; } \\
\text { Distribuição da cartilha de reciclagem; } \\
\text { Distribuição de caixas especificas para } \\
\text { coleta seletiva; Comunicados sobre regras } \\
\text { da Coleta Seletiva; Palestras; ecoficina de } \\
\text { brinquedos de sucata; Recursos da venda do } \\
\text { lixo para ações sociais e grêmio. }\end{array}$ & $\mathbf{O}$ \\
\hline & 9 - Eventos & $\begin{array}{l}9 \text { - Caminhada saudável; Concurso } \\
\text { SIPATS; Coral; Atividades no grêmio; } \\
\text { Visita dos familiares à empresa; Festas do } \\
\text { dia das crianças, juninas e de final de ano; } \\
\text { Sábado saudável }\end{array}$ & $\mathbf{S}$ \\
\hline & 10 - Semana da Saúde & 10 - Palestras, exames, avaliaçð̃es. & B \\
\hline & 11 - Ação solidária & 11 - Adoção de uma escola & $\mathbf{O}$ \\
\hline
\end{tabular}

Das empresas pesquisadas, noventa por cento (90\%) informaram que os seus programas de Qualidade de Vida no Trabalho foram avaliados. Elas utilizaram os seguintes instrumentos: Pesquisas de Satisfação, Estilo de Vida, WHOQOL, Clima Organizacional, Avaliação Física individualizada, a cada quatro meses. Avaliação médica anual e Inventário de queixas.

Apesar de, quase a totalidade das empresas ter informado que seus Programas de QVT foram avaliados, apenas trinta por cento (30\%) apresentaram os resultados dessas avaliações. Cinqüenta por cento $(50 \%)$ não informaram e vinte por cento (20\%) informaram resultados genéricos (positivos e redução da LER).

A seguir, os resultados quantitativos das três empresas que informaram: 
Tabela 11 - Resultados das Ações de QVT

\begin{tabular}{|c|c|}
\hline Empresas & Resultados \\
\hline 06 & $\begin{array}{l}\text { - O resultado foi de } 30 \% \text { na redução do número de } \\
\text { fumantes; } \\
\text { - Redução de } 504 \text { dias para } 39 \text { os dias de ausência } \\
\text { no ano motivados por gripe } \\
\text { - Participação de aprox. } 350 \text { colaboradores } \\
\text { gripe - ação foi a vacinação contra a gripe - com } \\
\text { - Redução de } 11 \% \text { de hipertensos } \\
\text { - Redução de } 1998 \text { ( } 504 \text { dias), } 1999 \text { ( } 87 \text { dias) e } \\
2000 \text { (43 dias) de afastamentos por motivo de gripe }\end{array}$ \\
\hline 09 & $\begin{array}{l}\text { - Redução da DORT em } 96 \% \\
\text { - Redução de acidente de trabalho em } 36 \% \\
\text { - Diminuição do absenteísmo em } 72 \% \\
\text { - Diminuição de sedentários de } 74 \% \text { em } 1997 \text {, para } \\
48 \% \text { em } 2001 \text {. } \\
\text { - Diminuição de hipertensos de } 11 \% \text { m } 1997 \text {, para } \\
5 \% \text { em } 2001 \text {. } \\
\text { - Diminuição de fumantes de } 26 \% \text { em } 1997 \text {, para } \\
15 \% \text { em } 2001 \text {. }\end{array}$ \\
\hline 10 & $\begin{array}{l}\text { - Hiperglicemia: diminuição da população de } 7 \% \\
\text { para } 1 \% \text {. } \\
\text { - Hipertensão: Diminuição da população de } 5 \% \\
\text { para } 3 \% \\
\text { - Sedentarismo: Redução de } 62 \% \\
\text { - Academia de Ginástica: } 52 \% \text { praticam atividade } \\
\text { física } \\
\text { - IMC: Aumento da população com IMC entre } 20 \text { e } \\
25 \text { em } 9 \% \\
\text { Redução da população com IMC entre } 26 \text { e } 30 \text { em } \\
6 \% \\
\text { Redução da população com IMC } 30 \text { em } 5 \% \\
\text { - Colesterol : Aumento de } 15 \% \text { na faixa de } \\
\text { normalidade ( até } 200 \text { mg/dl) } \\
\text { Redução de } 7 \% \text { na faixa entre } 201 \text { e } 239 \mathrm{mg} / \mathrm{dl} \\
\text { Redução de } 8 \% \text { na faixa acima de } 241 \mathrm{mg} / \mathrm{dl}\end{array}$ \\
\hline
\end{tabular}

Convém observar, que não se pesquisou a metodologia utilizada para o cálculo dos números informados. Como sugestão para um aprofundamento dos dados e possível trabalho futuro, a amostra deveria ser constante, descontando-se o impacto que, eventualmente, $o$ índice de rotatividade pode causar. 


\subsection{5 - Avaliacão dos Programas de OVT}

A quase totalidade $(90 \%)$ avalia os seus programas de QVT junto aos funcionários e ao corpo diretivo. A visão de todos é muito boa, indicando que o as açð̃es de QVT auxiliam na construção de uma imagem organizacional interna bastante positiva. Foi citada também, a melhoria da imagem externa da empresa, através do reconhecimento dos familiares dos empregados e também pela projeção positiva que os prêmios da $\mathrm{ABQV}$ tem junto à comunidade.

Se analisarmos dentro do modelo de gestão de QVT de França (2003, op.cit), esses dados referem-se ao fator crítico legitimidade e evidenciam a importância que das ações de QVT junto aos respondentes.

Gráfico 11 - Avaliação dos programas de QVT junto aos funcionários

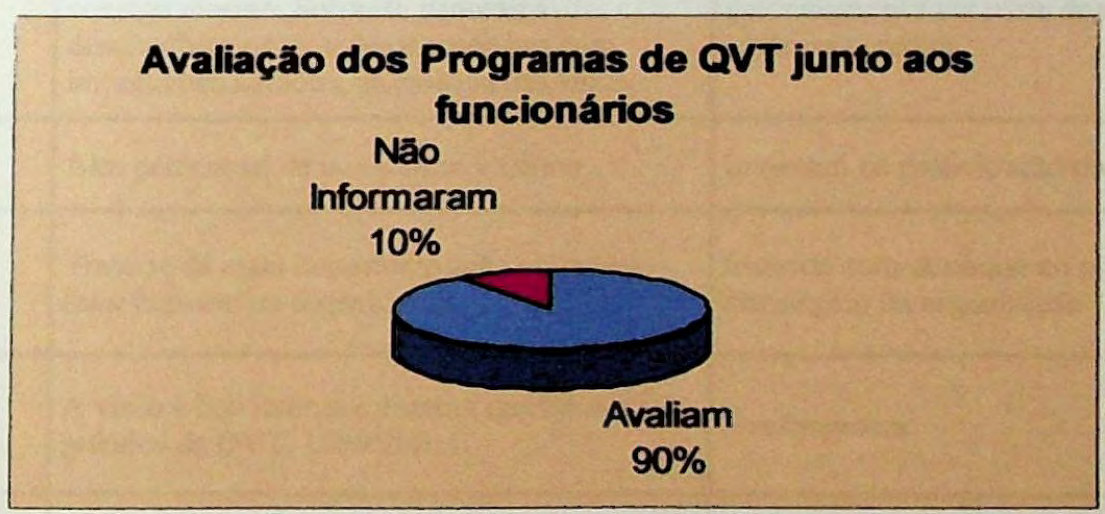


Tabela 12 - Visão dos funcionários e da diretoria dos Programas de QVT

\begin{tabular}{|c|c|c|}
\hline EMPRESA & VISÃO DOS FUNCIONÁRIOS & VISÃO DA DIRETORIA \\
\hline 01 & $\begin{array}{l}\text { A legitimação da importância para a vida dos } \\
\text { funcionários é confirmada através dos } \\
\text { questionários e depoimentos }\end{array}$ & $\begin{array}{l}\text { Não há uma política interna ou, uma definição } \\
\text { corporativa para os programas. Na diretoria, } \\
\text { confirmam a importância de trabalhar QVT, } \\
\text { porém temos ainda que ampliar a visão. }\end{array}$ \\
\hline 02 & $\begin{array}{l}\text { O funcionário se sente motivado e satisfeito } \\
\text { com a preocupação da empresa com a sua } \\
\text { saúde e bem-estar }\end{array}$ & $\begin{array}{l}\text { O programa é estratégico. A diferença pela } \\
\text { qualidade nos serviços se concretiza com } \\
\text { funcionários motivados e satisfeitos. }\end{array}$ \\
\hline 03 & NI & \\
\hline 04 & $\begin{array}{l}\text { Gostam muito e sugerem sempre novidades a } \\
\text { serem implantadas. }\end{array}$ & $\begin{array}{l}\text { Suporte total. Entende a importância do cuidado } \\
\text { preventivo com a saúde. }\end{array}$ \\
\hline 05 & $\begin{array}{l}\text { Excelente. O Programa possui um amplo } \\
\text { reconhecimento pelos empregados, por seus } \\
\text { familiares, por inúmeras empresas e } \\
\text { instituições e pela parte da sociedade que o } \\
\text { conhece. }\end{array}$ & $\begin{array}{l}\text { De incentivo e reconhecimento pelos prêmios } \\
\text { recebidos. }\end{array}$ \\
\hline 06 & $\begin{array}{l}\text { Altamente positivo, por ocasião do lançamento } \\
\text { as pessoas permanecem sensíveis ao tema e } \\
\text { observamos uma reação de melhor cuidado } \\
\text { consigo mesmo. Sob esse panorama } \\
\text { desenvolvemos as ações e contamos com } \\
\text { importantes adesões, na maioria das vezes. }\end{array}$ & $\begin{array}{l}\text { Esse processo de informação, ampliação de } \\
\text { conhecimento, suporte estímulo ao auto- } \\
\text { gerenciamento faz parte dos valores que a } \\
\text { empresa acredita. }\end{array}$ \\
\hline 07 & Alto percentual de notas Bom e Ótimo & Investem na participação dos funcionários \\
\hline 08 & $\begin{array}{l}\text { Trata-se da mais importante ação voltada ao } \\
\text { fator humano na organização }\end{array}$ & $\begin{array}{l}\text { Inserida com destaque no planejamento } \\
\text { estratégico da organização }\end{array}$ \\
\hline 09 & $\begin{array}{l}\text { A visão é boa interna e externa (ganhamos } 02 \\
\text { prêmios de QVT, 1999/2001) }\end{array}$ & É reforçadora \\
\hline 10 & $\begin{array}{l}\text { A visão dos funcionários com relação ao } \\
\text { programa é muito boa, pois já existe a cultura } \\
\text { saudável dentro da organização. Todos são } \\
\text { unânimes em dizer que este é o nosso } \\
\text { diferencial, como prova disso na pesquisa das } \\
100 \text { Melhores Empresas para se Trabalhar } \\
\text { fomos selecionados entre as melhores e os } \\
\text { ítens melhores avaliados foram os do } \\
\text { Programa de Qualidade de Vida. }\end{array}$ & $\begin{array}{l}\text { A visão da direção da empresa também é muito } \\
\text { positiva, pois os reconhecimentos dos } \\
\text { funcionários como sentir orgulho de trabalhar } \\
\text { na empresa, assim como todos os prêmios } \\
\text { alcançados nesta área repercutem muito } \\
\text { positivamente na Direção Geral da empresa. } \\
\text { A visão da empresa sempre está em linha com } \\
\text { objetivos propostos do Programa para melhoria } \\
\text { do bem estar do funcionário e sua família. }\end{array}$ \\
\hline
\end{tabular}




\subsubsection{Mudanca Organizacional}

Nesse item, foi perguntado às empresas se havia algum indicador de mudança organizacional, como consequência da implantação do Programa de QVT. Sessenta por cento (60\%) das empresas responderam que houve mudanças ligadas à melhoria da produtividade, rotatividade, absenteísmo e reclamações trabalhistas. Melhoria do clima organizacional e da saúde dos empregados; mudanças de hábitos dos empregados; melhoria da imagem da empresa no mercado de trabalho e também da imagem interna; Criação de uma área específica na empresa para o programa; $\mathrm{A}$ seguir, os dados detalhados.

\section{Tabela 13 - Mudança Organizacional}

\begin{tabular}{|c|c|}
\hline Empresa & Mudança Organizacional \\
\hline 02 & $\begin{array}{l}\text { O programa nasceu e cresceu acompanhando o crescimento da empresa. Outras ações } \\
\text { organizacionais que, em conjunto com o PQV fazem hoje, da empresa, uma das mais } \\
\text { cobiçadas na área em que atua, pelos profissionais. }\end{array}$ \\
\hline 04 & $\begin{array}{l}\text { Mudança de Hábitos verificada no acompanhamento dos exames periódicos e a } \\
\text { adesão aos programas }\end{array}$ \\
\hline 05 & $\begin{array}{l}\text { A satisfação com o Programa foi apontada como positiva por } 97 \% \text { dos empregados } \\
\text { em pesquisa efetuada.. }\end{array}$ \\
\hline 06 & $\begin{array}{l}\text { A criação da área específica - Relações Humanas no Trabalho- que congrega a área } \\
\text { médica e social da empresa.Além disso, o programa nos proporcionou sutilmente a } \\
\text { alteração da relação funcionário x empresa, deixando a forma acentuada de } \\
\text { paternalismo que existia. Claro que sabemos não foi fator único mas, associado a } \\
\text { outros aspectos, contribuiu para a maturidade dessa relação. }\end{array}$ \\
\hline 09 & $\begin{array}{l}\text { Está diretamente ligado ao clima organizacional e ao aumento de produtividade } \\
\text { (premissas básicas) }\end{array}$ \\
\hline 10 & $\begin{array}{l}\text { Melhor ambiente para se trabalhar. Orgulho de trabalhar na empresa. Os funcionários } \\
\text { valorizam mais os benefícios oferecidos pela empresa. O turn-over diminuiu, assim } \\
\text { como zeramos as nossas reclamações trabalhistas. } \\
\text { Grande melhoria da saúde com redução do número de absenteísmo por especialidade, } \\
\text { além dos outros índices de melhoria na saúde. }\end{array}$ \\
\hline
\end{tabular}




\subsubsection{Indices de Rotatividade e Absenteísmo}

Na tentativa de se apurar a correlação entre produtividade e Programas de QVT, solicitou-se junto às empresas pesquisadas as informações dos índices de rotatividade e absenteísmo dos três anos anteriores à implantação do Programa de QVT e dos anos seguintes. $\mathrm{O}$ conceito utilizado para rotatividade foi o de demissões tanto voluntárias como por iniciativa dos empregadores e o de absenteísmo, as faltas ocorridas por diversas razões, justificadas ou não.

Apenas $40 \%$ das empresas tinham disponíveis informações relacionadas com a rotatividade e o absenteísmo, porém não dos anos anteriores à criação do Programa de QVT, o que impossibilita fazer uma análise da evolução desses dados, comparando-se o cenário anterior à implantação do Programa de QVT até o atual.

De acordo com o modelo conceitual de Gestão de QVT de França, (2003,op.cit) este item trata do fator crítico produtividade e indica que a mensuração desses dados ainda não foi adotada de maneira sistêmica.

De qualquer maneira, pode-se observar uma tendência à redução desses índices, conforme mostra a tabela a seguir:

Tabela 14 - Índices de Rotatividade e Absenteísmo

\begin{tabular}{|c|c|c|c|}
\hline Empresa & $\begin{array}{c}\text { Ano de Criação } \\
\text { do Programa }\end{array}$ & Rotatividade & Absenteísmo \\
\hline 05 & 1999 & $\begin{array}{l}\cdot 1999-11,1 \% \\
.2000-13,1 \% \\
.2001-12,3 \% \\
\cdot 2002-9,5 \%\end{array}$ & ND \\
\hline 07 & 1999 & $\begin{array}{l}\cdot 2000-12 \% \\
\cdot 2001-12 \% \\
\cdot 2002-12 \%\end{array}$ & $\begin{array}{l}\cdot 2000-1,3 \% \\
\cdot 2001-1,1 \% \\
\cdot 2002-1,0 \%\end{array}$ \\
\hline 09 & 1997 & nd & $\begin{array}{c}1997-2,64 \\
1998-1,67 \\
1999-0,74\end{array}$ \\
\hline 10 & 1998 & $\begin{array}{c}2000-15,99 \% \\
2001-10,45 \% \\
\text { (falta apurar dois } \\
\text { meses) }\end{array}$ & $\begin{array}{c}2000-12,07 \% \\
2001-13,12 \% \\
2002-8,84 \%\end{array}$ \\
\hline
\end{tabular}


Gráfico 12 - Empresas que informaram dados de Rotatividade e Absenteísmo

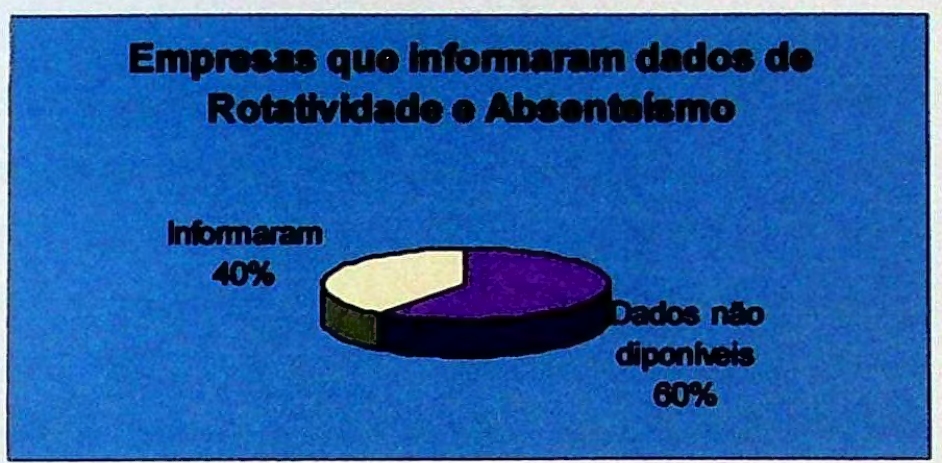




\section{Parte 3}

Discussão dos Resultados e Conclusōes 


\section{1 - DISCUSSÃO}

Os modelos de gestão de Recursos Humanos têm-se dedicado às práticas voltadas para o desenvolvimento dos empregados e as relaçð̃es de trabalho, tais como, recrutamento e seleção, treinamento e desenvolvimento, gestão de carreiras e competências, remuneração, benefícios, gestão do desempenho e clima organizacional. Os modelos de Qualidade de Vida no Trabalho e de Comprometimento Organizacional apresentam caminhos muito parecidos: promover o desenvolvimento dos empregados, garantir a justiça organizacional, equilíbrio entre a vida familiar e profissional, envolvimento e participação nos processos da empresa, responsabilidade social, entre outros. As práticas de Recursos Humanos estão incluídas nos modelos de Qualidade de Vida no Trabalho, resultando em um modelo de Gestão de QVT abrangente.

Essa abordagem holística da relação empregado-empresa, já existia nos estudos desenvolvidos na década de 50 do século passado, sobre as teorias de motivação, como a hierarquia de necessidades, de Maslow e a teoria de motivação-higiene de Herzberg (Robbins, 1998). Nelas, os autores ponderam as necessidades dos empregados vinculadas à satisfação no trabalho. Maslow relaciona as necessidades fisiológicas, de segurança, social, estima e auto-realização. Herzberg detalha mais esse modelo e relaciona as necessidades de segurança, status, relacionamento com subordinados, colegas e chefia, salário, condiçð̃es de trabalho, vida pessoal, supervisão, política e administração da empresa, crescimento, progresso, responsabilidade, o próprio trabalho, reconhecimento e realização.

Essas mesmas necessidades estão inseridas no modelo bio-psico-socialorganizacional de Qualidade de Vida já mencionado. A maior contribuição dada pelo modelo de gestão de QVT está em sair de um modelo conceitual para o estabelecimento de práticas, como as ações vistas na pesquisa realizada.

Observa-se, porém, que a percepção dos pesquisados é de um modelo de QVT restringido às ações que promovem o bem-estar, mais ligadas à saúde e segurança do trabalhador.

Vale ressaltar, que o conceito de responsabilidade social também está muito presente nos programas de QVT. A própria pesquisa sobre alimentação e nutrição revela uma 
evolução sobre o tema. . Inicialmente as empresas estavam preocupadas com a alimentação e o desgaste da força de trabalho: surgiu o Programa de Alimentação do Trabalhador - PAT. Na pesquisa, verificou-se que a preocupação atual é com um outro problema que já atinge a dimensão de estudos epidemiológicos: a obesidade e as doenças relacionadas a ela, como as cardiovasculares. Nessa área, as empresas têm desenvolvido um importante papel de orientação, educação e conscientização para a prevenção dessas doenças, junto a seus funcionários e familiares, cumprindo um importante papel social.

\section{2 - CONCLUSÕES}

A partir dos conceitos incorporados, da pesquisa de campo e da análise dos resultados apurados, pode-se concluir que a maioria das empresas pesquisadas está desenvolvendo ações, dentro dos seus programas de QVT, de orientação dos hábitos alimentares de seus funcionários, promovendo a saúde na tentativa de diminuir a incidência de doenças relacionadas a uma dieta inadequada, especificamente as relacionadas à obesidade, como as doenças coronarianas. Elas estão cumprindo um importante papel social, não delegando as ações de promoção de saúde à esfera das autoridades governamentais. Quanto aos resultados quantitativos apurados, pode-se afirmar que a maioria dos programas de QVT não informou a utilização de indicadores de avaliação específicos. Porém, aquelas que possuíam, informaram resultados positivos, com um decréscimo nas taxas de colesterol e glicemia, da hipertensão, redução da população com IMC acima de 26 e da taxa de sedentarismo. Pode-se concluir, então, que há uma correlação positiva entre os programas de QVT e a diminuição da obesidade e doenças coronarianas e, conseqüentemente, na mudança de hábitos alimentares, nas empresas que possuem indicadores da eficácia do programa.

Não foi possível fazer um estudo conclusivo sobre o impacto do investimento no capital humano por essas empresas, uma vez que os índices de rotatividade e absenteísmo informados não são consistentes para se avaliar a sua correlação com a produtividade. Ainda assim, mesmo não tendo representatividade estatística, os dados sugerem diminuição, especialmente no índice de absenteísmo. 
A percepção dos resultados dos programas de QVT, tanto por parte dos empregados, como do corpo diretivo é que houve uma melhoria do clima organizacional e da imagem da empresa interna e externamente, além da mudança de hábito e melhoria do bem-estar dos empregados, o que indica que os objetivos dos programas de QVT foram atingidos, considerando-se a visão dos pesquisados. A conclusão final a que se chega neste estudo é a de que a gestão de Qualidade de Vida no trabalho tem importante papel para a organização e para os indivíduos que fazem parte dela. Porém, há o reconhecimento da necessidade de aprofundamento e da realização de estudos futuros.Fica a sugestão da realização de múltiplos estudos de caso, com especial atenção na investigação dos indicadores de avaliação, com o objetivo de se obter resultados mensuráveis que levem à associação entre QVT e aumento de produtividade. 


\section{Referências \\ Bibliográficas}




\section{REFERÊNCIAS BIBLIOGRAFICAS:}

ALBUQUERQUE, L.G. e FRANÇA, A.C.L. Estratégias de RH e gestão de Qualidade de Vida no Trabalho. Revista de Administração - RAUSP, v.33, n.2, p.40 - 51, São Paulo, abr/jun -1998.

ALFIN-SLATER, R.B. \& KRITCHEVSKY, D., Human Nutrition, a comprehensive treatise, Plenum Press, New York and London, 1980

ANJOS, L.A. Índice de Massa Corporal (massa corporal.estatura ${ }^{-2}$ ) como indicador do estado nutricional de adultos: revisão da literatura. Revista Saúde Pública, 26(6):431-6, São Paulo, 1992.

AGUIAR, M.F. Lazer e Produtividade no trabalho, ENANPAD, 2000.

BALLESTEROS, R. F. Qualidade de vida: conceito e acesso. Video. Montreal, 1996.

BASTOS, A.V.B.; BRANDÃO,M.G.A.; PINHO, A.P.M. Comprometimento organizacional: uma análise do conceito expresso pôr servidores universitários no cotidiano do trabalho. Revista de Administração contemporânea, v.1, n.2, p.97 $120,1997$.

BASTOS, A.V.B. Medidas de comprometimento no contexto de trabalho: um estudo preliminar de validade discriminante. Psico, v.2, n.24, p.29-48, 1992.

BECKER, G.S. Human Capital. A theoretical and Empirical Analysis, with special reference to Education. The University of Chicago Press, 3rd Edition, Chicago and London, 1993 
BERGERON, J.L. La qualité de vie au travail:de quoi parle-t-on? Revue Commerce. Montrèal. N.1, Jan.1982

BENNETT, A. C. Productivity and the Quality of Work Llife in Hospitals, Published by American Hospital Publishing Inc., USA, 1983

CALDER, B.J., Focus groups and the nature of qualitative research. Journal of Marketing Research, v. 14, 1977

CAMPINO, A.C.C., CACCIAMALI, C. E CYRILlO D. Avaliação SócioEconômica do Programa de Alimentação do Trabalhador, 1982.

CAMPINO, A.C.C. Economia e Educação. Revista da Faculdade de Educação, v.1/2, p 5-36, São Paulo, 1986.

CERVATO, A. M., MAZZILLI, R.N.,MARTINS, I.S. e MARUCCI, M.F. Dieta habitual e fatores de risco para doenças cardiovasculares, Revista Saúde Pública, 31 (3):227-35, 1997.

CHIAVENATO, I. Administração de Recursos Humanos: Fundamentos Básicos. Atlas, São Paulo, 1999.

COMOLAZIO, F. Nutritional Status and Work capacity Relationships in Premier Symposium International Alimentation et travaié, 1972.

DAVIS.L.E., CHERNS, A.B. et col. The quality of working life. The Free Press, New York, 1975.

DESSLER, G. How to earn your employee's commitment. Academy of Management Executive, Vol.13. № 2, 1999.

ELLIG, B.R. E MINEHAN,M. Focando o futuro: RH no Século 21, 1997 
ESTES, G.M., KUESPERT, D, Delphi in Industrial Forecasting, Chemical \& Engineering News, Agosto, p.. 40-47, 1976

FERNANDES, E. Qualidade de Vida no trabalho. Como medir para melhorar. Casa da Qualidade, Salvador, BA, 1996

FISCHER, A. L., A constituição do modelo competitivo de Gestão de Pessoas no Brasil - Um estudo sobre as empresas consideradas exemplares. Tese apresentada à Faculdade de economia, Administração e Contabilidade da Universidade de São Paulo, como parte dos requisitos para obtenção do Título de Doutor em Administração, 1998.

FISCHER, A. L, e ALBUQUERQUE, L.G. Relatório da pesquisa tendências de mudanças na gestão de pessoas das empresas brasileiras :DELPHI RH-2010 PROGEP/MBA/USP, São Paulo, 2001.

FRANÇA, A.C.L. Interfaces da QVT na Administração de empresas: Fatores críticos da Gestão Empresarial para uma nova competência. Tese para concurso de Livre-docência apresentada à Faculdade de economia, Administração e Contabilidade da Universidade de São Paulo, 2001.

. Qualidade de Vida no Trabalho - QVT . Conceitos e práticas nas empresas da sociedade pós-industrial. Atlas, São Paulo, 2003.

FRANÇA A. C. L e RODRIGUES A. L Stress e Trabalho - Uma abordagem psicossomática. Atlas, São Paulo, 1999.

FONSECA, E G. O Capital Humano na filosofia Social de Marshall, Revista de Economia Política, vol.12, n² (49), abril-junho/ 1992.

GARROW, J.S. Obesity and related diseases. Churchill Livingstone, Edinburgh, London, Melbourne and New York, 1988. 
GIDDENS, A. A terceira via. Reflexdes sobre o impasse politico atual e o futuroda social-democracia. Record, Rio de Janeiro e São Paulo, 2001

GOULARD, I. R. e SAMPAIO, J. R. Qualidade de vida no trabalho: uma análise da experiência de empresas brasileiras, in Qualidade de Vida, Saúde Mental e Psicologia Social. Estudos Contemporâneos II, Sampaio, J. R. (organizador), Casa do Psicólogo, SP, 1999.

HACKMAN, R. e OLDHAM, G.R. Development of the job diagnostic survey. Journal of Applied Psychology. V.60, n.2, p. 159-70, 1975.

HUSE, E. \& CUMMINGS, T. Organization development and change. Minn., West Publishing, 1985.

JAROS, S.J. An assess11ment of Meyer and Allen's (1991) three component model of organizational commitment and turnover intentions. Academy of Management journal, Best papers proceedings 1995, 317-321, 1995.

KRUMMEL, D. Nutrição na Doença Cardiovascular. In: Mahan, L.K., Escottstump, S. Krause alimentos, nutrição e dietoterapia, $9^{a}$ edição, Roca, São Paulo, 1998.

LEVINSON, W.A. Mutual Commitment. Executive Excellence, vol.16, iss.6, p.19, USA,jun/99

LINSTONE, H.A., TUROFF, M., The Delphi Method - Techniques and Applications, Addison Wesley, Reading, Mass., 1975.

LOTUFO, P.A. Epidemiologia das doenças cardiovasculares no Brasil: histórico, situação atual e proposta de modelo teórico. Revista Sociedade Cardiologia. São Paulo, v.6, n.5, p.541-7, 1996. 
LOTUFO P.A. e LOLIO, C.A., Tendências de evoluçăa da mortalidade por doenças cardiovasculares: o caso do Estado de São Paulo, in Velhos e Novos Males da Saúde no Brasil: a evolução do país e de suas doenças, Carlos Augusto Monteiro (organizador), Hucitec, NUPENS/USP, São Paulo, 2000.

KRAUSE, M. V. e MAHAN, L. K. Alimentos, Nutrição e Dietoterapia, Roca, São Paulo, 1994.

MEDEIROS, J. A. S. Alcance e Limitaçőes da Teoria do Capital Humano. Diferentas de ganhos no Brasil em 1973. Instituto de Pesquisas Econômicas, Série Ensaios Econômicos, v.17, São Paulo, 1982.

MENDELEWSKI, F.F e ORREGO, H.Z. Calidad de la vida de trabajo. Dissertação para título de Mestrado em Administração de Empresas na Faculdade de ciências econômicas e administrativas da Universidad de Chile, Santiago do Chile, 1980.

MENDES, A. Inspiring Commitment. How to win employee loyalty in chaotic times, Irwin Professional Publishing, USA, 1996

MEYER, J. P. e ALLEN, N. Commitment in the workplace: Theory, Research and Application. Saage Publications, Thousand Oaks, CA, 1997.

MEYER, J.P.; ALLEN, N.J. e SMITH, C.A. Commitment to organizations and occupations: extension and test of a three-component conceptualization. Journal of Applied Psychology, 78(4), 538-551, 1993.

MINISTÉRIO DA SAÚDE, Doenças Cardiovasculares no Brasil - Sistema Único de Saúde - SUS: Dados Epidemiológicos; Assistência Médica. Secretaria de Assistência à Saúde, Departamento de Programas de Saúde, Coordenação de Doenças Cardiovasculares, Brasília, 1993. 
MITCHELL, V., Using Delphi to Forecast in New Technology Industries. Marketing Intelligence \& Planning, Vol. 10, № 2, p. 4-9, MCB University Press, 1992.

MONDINI, L., MONTEIRO C.A. Mudanças no Padrāo de Alimentaçāo, 1995

MONTEIRO, C., BENICIO, M. H. D'A, MONDINI, L. \& POPKIN, B.M. Factores econômicos y culturales asociados a obesidad: el caso de Brasil, in Obesidad: um desafio pendiente , ALBALA, C; KAIN, J; BURROWS, R \& DÍAZ, E. Editorial Universitária, Santiago de Chile, 2000.

MONTEIRO, C.A. \& HALPERN, A. Epidemiología de la obesidad en Brasil, Nutrición y Obesidad, 3(2), 2000

MORAES, L.F.R. e KILIMNIK, Z.M. Comprometimento organizacional, qualidade de vida e stress no trabalho: uma abordagem de diagnóstico comparativo. Relatório de Pesquisa. CEPEAD/FACE/UFMG. Belo Horizonte, 1994.

MORROW, P.C. The theory and measurement of work commitment. Jai Press Inc., London, 1993.

MULlER, G. Nutriçăo e Desenvolvimento Econômico, in Nutrição e Desenvolvimento Econômico, CAMPINO, A. C.C., IPE/USP, 1983

NADLER, D.A. e LAWLER, E.E. III. Calidad de vida de Trabajo: Perspectivas y orientaciones, Organizational Dynamics, Winter, 1983. (Traduccion: Teresa Collados Baines) 
NEUMANN, A.I.C.P, PHILIPPI, S.T., CRUZ, A.T.R., MORIMOTO, J.M. e FISBERG, R.M. A pirâmide alimentar na orientação nutricional de indivíduos portadores de doenças cardiovasculares, Nutrire: Revista da Sociedade Brasileira de Alimentação e Nutrição, São Paulo, SP, v. 19/20, p.7-17, Dezembro de 2000.

OLIVEIRA, M.A. P. S. ; LIMA, S.M.V. e BORGES-ANDRADE, J.E. Comprometimento no trabalho e produção científica entre pesquisadores brasileiros, Revista de Administração - RAUSP, São Paulo, v.34, n.3, p.12 - 20, 1999.

PAIVA, K.C.M. e MARQUES, A.L. Qualidade de Vida, Stress e Situação de Trabalho de Profissionais Docentes: uma comparação entre o público e o privado. SEMEAD, 1999.

PIMENTA, C. D. Prevalência de sobrepeso e obesidade em adolescentes de diferentes níveis sócio-econômicos. Dissertação de mestrado apresentada ao departamento de Nutrição da Faculdade de Saúde Pública da Universidade de São Paulo, São Paulo, 2000

RICCO, M. F. F. Comprometimento Organizacional em condiçōes adversas: o caso dos pesquisadores do Centro Técnico Aeroespacial. Tese Mestrado, FEA/USP, 1998

ROBBINS, S.P. Comportamento Organizacional. LTC S.A., Rio de Janeiro, 1998.

SCHULTZ, T.W. O valor econômico da educação. Zahar Editores, Rio de Janeiro, 1973.

SELLTIZ, C., JAHODA,M, DEUTSCH,M., COOK,S.M. Método de pesquisa das relações sociais, São Paulo, Herder, 1965 
STUM, D.L. Workforce Commitment: strategies for the new work order. Strategy and leadership, vol:27, iss $1, \mathrm{Jan} / \mathrm{fev} / 99, \mathrm{p} .4-7$.

TARTAGLIA, J.C. Desenvolvimento, fome e segurança alimentar, in Segurança Alimentar e Cidadania , coletânea de Maria Antonia M. Galeazzi, Campinas, SP: Mercado das Letras, 1996.

TAYLOR, R. E. , MEINHARDT, D.J., Defining Coputer Information Needs for Small Business: A Delphi Method. Journal of Small Business Management, Vol.23, $N^{\circ} 2$, Abril, p. 3-10. 1985.

TEET, R.; MEYER J.P. Job satisfaction, organizational commitment, turn-over intention and turnover: path analyses based on meta-analytic findings. Personnel psychology, 46, 259-283, 1993.

VALlARIO, M. Work Life Programs. Compensation \& Benefits Management, Summer 1997

VICHAS, R.P., Complete Handbook of Profiteble Marketing Research Techniques. Englewood Cliffs, Prentice-Hall, Inc. 1982

YIN. R.K. case study research:design and methods. Newbury, Sage Publications, 1988.

WALTON, R.E. Quality of working life: What is it? Sloan Managemente Review, V.15, n. 1, 1973

- La calidad de la vida en el trabajo: su significado e importância. Administración de Empresas. Ano 6, n.71, fevereiro de 1976.

Gestão de Pessoas, não de Pessoal - Os melhores métodos de motivação e avaliação de desempenho, Harvard Business Review Book, Campus, Rio de Janeiro, 1997 
WHEELWRIGHT, S.C., MKRIDAKIS, S., Forecasting Methods for Management, John Wiley \& Sons, USA, 1973

WETHER,W.B. \& DAVIS, K. Administração de Pessoal e Recursos Humanos., Mc Graw Hill, São Paulo, 1983.

WESTLEY, W.A. Problems and solutions in the Quality of Working Life. Human Relations, 1979.

WHO. Obesity: prevening and managing the global epidemic. Report of a WHO Consultation on Obesity. Ginebra:OMS, 1998

WHO Study Group. Diet, Nutrition and Prevention of Chronic Diseases. WHO Technical Report Series, 797, 1990.

WRIGHT, J. T. C., A Técnica Delphi: Uma Ferramenta Útil para o Planejamento no Brasil?. In.: II Encontro Brasileiro de Planejamento Empresarial - Como Planejar 86. Anais. São Paulo: SPE - Sociedade Brasileira de Planejamento Empresarial, p. 199-207, 1985.

WRIGHT, J. T. C., A Técnica Delphi, Programa de Estudos do Futuro. São Paulo: Fundação Instituto de Administração. Mimeo,1994. 
ANEXO 1 


\section{A importância da alimentaç̃o na saúde}

Tendo como base o livro Alimentos, Nutrição e Dietoterapia de Krause e Mahan (1994) e das aulas presenciais realizadas na Faculdade de Farmácia da Universidade de São Paulo, na disciplina Fundamentos Biológicos da Nutrição Humana Aplicada ministrada pelos professores Silvia M. F. Cozzolino, Fernando Salvador Moreno e Julio Orlando Tirapegui, apresenta-se, a seguir, a importância dos principais nutrientes para a saúde, suas fontes e as decorrências de carência desses elementos.

\section{Proteínas}

A base estrutural das proteínas são os aminoácidos, que se combinam para formar proteínas através de uma ligação peptídica, que une o carbono carboxólico de um aminoácido ao nitrogênio de outro.

As proteínas da dieta estão envolvidas na síntese do tecido protéico e outras funções metabólicas especiais. Nos processos anabólicos fornecem o aminoácido necessário para a construção e manutenção dos tecidos corpóreos. Desempenham um papel estrutural principal não apenas em todos os tecidos do corpo, mas também na formação de enzimas, fluidos e secreções corpóreas. Como anticorpos, estão envolvidas na função do sistema imunológico.

Na forma de lipoproteínas, participam no transporte de triglicerídeos, colesterol, fosfolipídios e vitaminas lipossolúveis. Muitas vitaminas e minerais estão ligados a carreadores específicos de proteinas para transporte.

As proteínas também contribuem para a homeostase, mantendo normais as relaçðes osmóticas entre os fluidos do corpo, conforme evidenciado pelo aparecimento de edema, como conseqüência de hipoproteína. 
Uma baixa ingestão de proteínas pode ser tolerada por adultos e crianças, dependendo da qualidade da proteína ingerida e do nível de ingestão energética. A partir de um ponto crítico, o organismo não pode continuar se adaptando e ocorre o desenvolvimento de deficiência protéica com edema, deterioração dos tecidos do organismos, da gordura hepática, dermatose e diminuição na resposta imunológica, fraqueza e perda do vigor.

As principais formas de Desnutrição Protéico-Calórica são Marasmo, onde a deficiência é primariamente da energia fornecida pelo alimento; Kwashiorkor, causado pela deficiência protéica; e Kwarshiorkor Marásmico, no qual estão presentes as deficiências protéico-calóricas do organismo.

O Marasmo é uma condição crônica de semi-inaniçăo com a qual a criança se ajusta de alguma forma através de redução no crescimento. Em estágios avançados é caracterizada por debilidade muscular e ausência de gordura subcutânea.

O Kwashiorkor aparece geralmente nas fases de 1 a 4 anos e conduz a hipoalbulenemia, edema e aumento da gordura hepática. A gordura subcutânea usualmente é preservada, mas a debilidade muscular frequentemente é mascarada pelo edema.

O Kwashiorkor marásmico combina sintomas de ambos os estados de deficiência, com a perda de gordura tornando-se muito evidente quando ocorre a redução do edema nos estágios iniciais do tratamento.

As principais fontes de proteínas são os alimentos de origem animal, como carne, ovos, aves, peixes, leite e derivados de leite, que suprem $65 \%$ das proteínas. Os produtos vegetais mais ricos em proteínas săo legumes - feijão de soja, amendoim, ervilha, feijão e lentilhas. 


\section{Carboidratos:}

Os Carboidratos são componentes orgânicos constituídos por carbono, hidrogênio e oxigênio. Eles variam de açúcares mais simples constituídos por 3 a 7 átomos de carbonos até polímeros muito complexos. Apenas as Hexoses (açúcares com 6 carbonos) e as pentoses (açúcares com 5 carbonos) e seus polímeros desempenham um papel importante na nutrição.

Todos os carboidratos se formam a partir da glicose, originando aqueles cuja complexidade é maior, e estão relacionados com os açúcares simples ou sacarídeos.

Os principais monossacarideos que ocorrem livres nos alimentos são Glicose e Frutose.

- A Glicose é abundante em frutas, milho doce, xarope de milho, mel e certas raízes. Sofre oxidação nas células como fonte de energia e é armazenado nos músculos na forma de glicogênio.

- A Frutose é encontrada junto com a glicose e sacarose no mel e nas frutas e é o mais doce dos açúcares.

Os dissacarídeos consistem de duas moléculas de monossacarídeos e, pelo menos uma delas é a glicose. São três os dissacarídeos comuns:

- Sacarose, que é o açúcar comum encontrado principalmente na cana-de-açúcar, açúcar de beterraba, melaço, suco e açúcar de bordo, bem como em frutas, vegetais e mel.

- A Maltose (açúcar do malte) não ocorre livre na natureza. É gerada durante os processos de digestão por enzimas que quebram as moléculas grandes de amido 
em fragmentos de dissacarídeos, os quais podem ser convertidos em duas moléculas de glicose para facilitar a absorção.

- A Lactose é o principal açúcar encontrado no leite. É encontrado exclusivamente nas glândulas mamárias de animais em estado de lactação. É menos solúvel que outros dissacarídeos e seu poder adoçante é de cerca de um sexto do poder adoçante da glicose.

Os Polissacarídeos de interesse na nutrição são o Amido, dextrina, glicogênio e celulose.

- O Amido é encontrado apenas em plantas e encontram-se encerrados dentro das células dos vegetais por paredes de celulose. São insolúveis em água fria. O cozimento amacia e rompe a célula, tornando o amido disponível para os processos digestivos enzimáticos.

- As Dextrinas são produtos intermediários que ocorrem na hidrólise do amido. São encontradas em produtos como o xarope de milho.

- O Glicogênio é forma de armazenamento de carboidratos em humanos e outros animais, e constitui a fonte primária e mais prontamente disponível de glicose e energia.

- A Celulose ocorre apenas em vegetais: frutas e polpas de vegetais, peles, talos, folha e outras formas de revestimentos de grãos, nozes, sementes e legumes. A Hemicelulose difere da celulose porque possui menos unidades de glicose.

Os carboidratos funcionam principalmente na forma de glicose, embora alguns poucos desempenhem função estrutural. Os carboidratos constituem a principal fonte de energia. Cada grama fornece aproximadamente $4 \mathrm{kcal}$, independente da fonte. A Glicose $\hat{e}$ indispensável para a manutenção da integridade funcional do tecido 
nervoso e sob circunstâncias normais, é a única fonte de energia no cérebro. A presença de carboidratos é necessária para o metabolismo normal de gorduras.

\section{Lipídios:}

O termo geral "lipídio" engloba um grupo heterogêneo de componentes, incluindo óleos, gorduras, ceras e correlatos, encontrados em alimentos e no organismo humano. Apresentam as seguintes propriedades comuns:

- São insolúveis na água;

- São solúveis em solventes orgânicos, como éter e clorofórmio;

- São passíveis de serem utilizados por organismos vivos.

Segundo Moreno (comunicação pessoal, Universidade de São Paulo, SP, 00), os lipídeos geram energia, protegem os órgãos vitais, participam da composição das membranas celulares, que são compostas com bicamada de fosfolipídeo, aumentam a palatabilidade, são precursores de hormônios (especialmente o colesterol), são importantes no transporte e absorção de vitaminas no trato intestinal, reduzem o volume da alimentação e aumentam o tempo de digestão.

A maioria das gorduras naturais é constituída por 98 a $99 \%$ de triglicerídeos, que por sua vez săo primariamente constituídos por ácidos graxos. O remanescente 1 ou $2 \%$ inclui traços de monodiglicerídeos e diglicerídios, ácidos graxos livres, fosfolipídios e substâncias não saponificáveis, contendo esteróis.

Um ácido graxo com uma cadeia de carbono contendo todos os átomos de hidrogênio possíveis é chamado ácido graxo saturado. Um ácido graxo insaturado contém uma ou mais duplas ligą̧̃es, onde poderiam estar ligados átomos adicionais de 
hidrogênio. Ácidos graxos monoinsaturados contêm apenas uma dupla ligação. Ácidos graxos poliinsaturados contêm duas ou mais duplas ligaçð̃es.

Os ácidos graxos poliinsaturados essenciais são o ômega-6 e ômega-3. Os ácidos alfa-linolênico e linoléico são denominados essenciais por não poderem ser sintetizados pelo organismo humano, mas oferecidos a este, como parte da dieta.

Os ácidos graxos, com atividade de ácidos graxos essenciais, ocorrem nos ésteres do colesterol e fosfolipídios no plasma e em lipoproteínas mitocondriais. Também são precursores de prostaglandinas, tromboxanos e prostaciclinas, um grupo de componentes semelhantes ao hormônio, que participam na regulação da pressão sangüínea, freqüência cardíaca, dilatação vascular, coagulação sangüínea, lipólise, esposta imunológica e sistema nervoso central.

Os ácidos graxos poliinsaturados essenciais desempenham importante papel no metabolismo e transporte de gorduras, função imune e manutenção, além da manutenção da função e integridade de membranas celulares.

A deficiência de Ácido Graxos Essenciais foi observada em lactentes nutridos com uma dieta livre de gordura, desenvolvendo uma dermatite característica (eczema) e em adultos que receberam alimentação endovenosa livre de gordura por período prolongado.

Os Triglicerídeos constituem a principal forma de armazenamento de energia. As gorduras poupam as proteínas para a síntese de tecidos, ao invés de serem utilizadas para a produção de energia. O tecido adiposo auxilia a manter órgãos e nervos em posição e a protegê-los contra choque e lesão traumática. A camada subcutânea de gordura isola o organismo, servindo para preservação do corpo com relação ao calor e manutenção da temperatura. AS gorduras auxiliam no transporte e absorção de 
vitaminas lipossolúveis. Deprimem a secreção gástrica e diminuem o perfodo de esvaziamento do estômago. Além disso, as gorduras auxiliam o paladar na dieta e produzem uma sensação de saciedade após as refeições.

As gorduras animais podem ser mais saturadas, exceto para óleos de plantas tropicais como palmeiras e óleo de coco; as gorduras vegetais são primariamente insaturadas. As gorduras de produtos alimentares de animais herbivoros (bife, leite de vaca e cordeiro) são mais saturadas e menos macias que gorduras de carne de porco e aves domésticas. O sabor de diferentes gorduras determina as diferenças no sabor dos vários tipos de carne.

Ácidos graxos em gorduras de peixes são compostos predominantemente por 20 a 22 átomos de carbono em extensão e são altamente insaturados, com a maioria dos ácidos na forma de ômega-3.

\section{Fibras}

As substâncias comumente denominadas como brutas ou fibras são componentes de origem vegetal que não constituem fontes de energia porque não podem ser hidrolizadas por enzimas do intestino humano. As substâncias vegetais indigeriveis incluem componentes da parede celular das plantas - celulose, hemicelulose e pectina - bem como substâncias do cimento intracelular e outras secretadas pela planta em resposta à lesão - gomas, mucilagens e polissacarídeos de algas. Alguns amidos têm sido modificados por processamentos doméstico e comercial e, por resistirem à ação enzimática são chamados amidos resistentes. 
O conteúdo em fibras dos alimentos tem sido descrito em termos de fibra crua, determinado pelas substâncias sujeitas à digestão por ácido e álcali. Como a ação real das enzimas digestivas é menos rigorosa, a quantidade de fibras remanescentes após a digestão no trato alimentar humano é consideravelmente superior àquela estimada pelos processos da fibra crua. Os valores obtidos para a fibra da dieta, como atualmente medidos, são usualmente de 2 a 5 vezes superiores àqueles para a fibra crua.

Os componentes da fibra da dieta podem ser classificados com base em suas propriedades físicas e papel fisiológico como:

- Fibras Solúveis - Incluem as pectinas, gomas, mucilagens e algumas hemicelulares. As pectinas são encontradas em frutas e vegetais, especialmente maçãs, laranjas e cenouras. Outras formas de fibras solúveis no trato alimentar está relacionada à sua habilidade de se ligar à água, formar géis e também no seu papel como substrato para fermentação de bactérias colônicas.

- Fibras Insolúveis - Consistem de celulose e algumas hemicelulose. Fazem parte da estrutura das células vegetais e são encontradas em todos os tipos de substância vegetal; entretanto sua principal fonte são as camadas externas de grãos de cereais.

Os efeitos fisiológicos das fibras na dieta são:

- Estimulam a mastigação, e assim, a secreção de saliva e suco gástrico.

- Enchem o estômago transmitindo uma sensação de saciedade.

- Aumentam o bolo fecal, que diminui a pressão intraluminar no colo.

- Normalizam o tempo de trânsito intestinal

- Tornam-se um substrato para fermentação por colônias de bactérias. 
- As fibras solúveis atrasam o esvaziamento gástrico, tornam mais lenta a digestão e absorção de nutrientes.

- Fibras solúveis diminuem os niveis séricos de colesterol.

\begin{abstract}
Algumas doenças do cólon parecem favoravelmente afetadas pelo aumento nos níveis das fibras da dieta e são denominadas constipação, diarréia, diverticulite e câncer colorretal. Além disso, a fração solúvel da fibra da dieta, quando oferecida em grandes quantidades, pode reduzir o colesterol do sangue. Também, as fibras hidrossolúveis, pectinas e gomas, exercem um efeito hipoglicêmico porque atrasam o esvaziamento gástrico, diminuem o trânsito intestinal, reduzem a absorçăo da glicose e tornam mais lenta a hidrólise do amido.
\end{abstract}

\title{
Minerais:
}

A análise do organismo humano revela a presença de uma grande variedade de minerais.

Os elementos minerais têm muitas funçð̃es essenciais, algumas como ions dissolvidos nos fluidos corpóreos e outras como constituintes de compostos essenciais. $\mathrm{O}$ equilíbrio dos íons minerais nos fluidos corpóreos regula a atividade de muitas enzimas, mantém o equilíbrio ácido-básico e a pressão osmótica, facilita o transporte de compostos essenciais nas membranas e mantém a irritabilidade dos músculos e nervos. Em alguns casos, os ions minerais săo constituintes estruturais 
dos tecidos do organismo. Muitos minerais estão envolvidos indiretamente no processo de crescimento.

Minerais como cálcio e o fósforo, que são necessários em quantidades de $100 \mathrm{mg} / \mathrm{dia}$ ou mais têm sido arbitrariamente designados como macrominerais. Os microminerais são os que estão presentes ou que são requeridos em quantidades pequenas, sendo também designados de oligoelementos ou ultra-oligoelementos.

Como macrominerais temos:

- Cálcio - É o mineral mais abundante do organismo. Constitui cerca de 1,5 a $2 \%$ do peso corpóreo e $39 \%$ dos minerais corpóreos. Cerca de $99 \%$ estão nos ossos e dentes. $\mathrm{O}$ restante, $1 \%$, está no sangue e fluidos extracelulares e dentro das células de tecidos moles, onde regula muitas funçðes metabólicas importantes. Além de construir e manter os ossos e dentes, o cálcio influi no transporte das membranas celulares, possivelmente atuando como um estabilizador desta membrana. Ele também afeta a transferência de íons através das organelas das membranas celulares, a liberação de neurotransmissores das junções sinápticas, a função dos hormônios protéicos e a liberação ou ativação das enzimas intra e extracelulares.

O cálcio é necessário na transmissão nervosa e regulação dos batimentos cardíacos. Um aumento significativo do cálcio sérico pode causar insuficiência cardíaca ou respiratória; uma diminuição pode resultar em tetania.

A vitamina $D$, na sua forma ativa estimula a absorção intestinal do cálcio através de uma série complexa de etapas, incluindo a transferência das células das bordas ciliadas das mucosas. Da mesma forma, a falta ou quantidade insuficiente de 
vitamina $D$, inibe a absorção de cálcio. A excessiva motilidade gastrointestinal diminui a absorção do cálcio. Estresse mental ou físico tende a diminuir a absorção e aumentar a excreção.

As fontes ricas em cálcio são o leite e seus derivados, vegetais verdes como couve, repolho crespo, folhas de nabo, mostarda e brócolis, sardinhas, mariscos, ostras e salmão enlatados.

A deficiência de cálcio pode causar anomalias na estrutura óssea como a osteoporose, osteomalacia e raquitismo.

- Fósforo - Além do papel estrutural nos ossos e dentes, é um componente essencial aos ácidos nucléicos e os fosfolipídeos são componentes-chave da membrana celular.

O fósforo é melhor absorvido quando ingerido em concentrações muito próximas da do cálcio. A vitamina $\mathrm{D}$ também favorece a sua absorção.

As fontes de fósforo são a carne, ovos, aves domésticas, peixes, leite e seus derivados, nozes, legumes, cereais e grăos.

A deficiência de fósforo pode acarretar anomalias neuromusculares, esqueléticas, hematológicas e renais.

- Magnésio - O magnésio está envolvido numa grande variedade de processos bioquímicos e fisiológicos, incluindo a contração muscular e a excitabilidade nervosa. Ë um constituindo normal do osso. Apesar do magnésio e o cálcio terem funçð̃es similares, podem ser antagonistas. Um excesso de magnésio inibe a 
calcificação óssea. Quando a ingestão de cálcio da dieta diminui, a absorção de magnésio aumenta.

Boas fontes alimentares são as castanhas, legumes, um grande número de grãos de cereais e vegetais verdes, nos quais o magnésio é constituinte essencial da clorofila.

A deficiência de magnésio é manifestada clinicamente por anorexia e falta de crescimento, perdas neuromusculares e cardíacas, tais como a fraqueza muscular, irritabilidade e descontrole mental.

- Enxofre - Ocorre no organismo humano, principalmente como um constituinte dos aminoácidos cistina, cisteína e metionina. Está presente em todas as proteínas, mas é mais importante na insulina e na ceratina da pele, cabelos e unhas.

- Sódio, Cloro e Potássio - Estão distribuídos ubiquamente em todos os fluidos e tecidos corpóreos, mas o sódio e o cloro são elementos extracelulares, enquanto o potássio é principalmente um elemento intracelular. Estão envolvidos na manutenção de quatro funçð̃es importantes fisiológicas do organismo: manutenção do balanço hídrico, equilíbrio osmótico, equilíbrio ácido-básico e irritabilidade muscular normal.

Por serem amplamente encontrados na natureza e na dieta comum, há muita pouca chance de uma deficiência no adulto normal.

Como microminerais ou oligoelementos pode -se destacar: 
- Ferro - Tem importância no transporte do oxig6enio e dióxido de carbono e está envolvido na maior parte ativa das enzimas que participam nos processos de respiração celular. Parece estar envolvido no sistema imunológico e na performance cognitiva.

O ácido ascórbico é o mais potente acelerador da absorção de ferro. O ferro só é perdido no organismo por sangramento e muito pouco excretado vias fezes, suor e na descamação normal da pele e cabelos.

A melhor fonte dietética do ferro é o figado, seguido por ostras, mariscos, rim, coração, carne magra, aves e peixes. Feijões secos são as melhores fontes vegetais. Outros alimentos que contêm ferro são gema de ovo, frutas secas, melaço, pães de trigo integral e enriquecidos, vinhos e cereais.

A falta de ferro é a mais comum de todas as deficiências minerais dos seres humanos, manifestando-se em última instância pelo aparecimento de anemia. A anemia ferropriva pode ser causada por traumas, hemorragias ou doenças gastrointestinais que interferem na absorção de ferro.

- Zinco - É encontrado tanto no reino animal como vegetal, e é o segundo em abundância depois do ferro. Participa das reações envolvendo tanto a síntese como a degradação da maioria dos metabólitos, como os carboidratos, lipídios, proteínas e ácidos nucléicos. Também está envolvido na estabilização das estruturas das proteínas e ácidos nucléicos, na integridade de organelas subcelulares, nos processos de transporte, função imunológica e na informação genética. 
- Cobre - O cobre tem um papel bem conhecido na oxidação do ferro plasmático, antes do transporte e da ligação-cruzada do colágeno necessária para sua tensão. Atua como parte integrante das enzimas, na produção de energia da mitocôndria, proteção de oxidantes e na síntese de melanina e catecolaminas.

Os alimentos ricos em cobre são: ostras, figado, rim, chocolate, nozes, legumes secos, cereais, frutas secas, aves e crustáceos.

A deficiência de cobre é indicada pela diminuição do seu nível sérico e da ceruplamina, e é seguida pela insuficiência de ferro, levando a anemia microcítica hemocrômica. Segue-se a neutropenia, leucopenia e a desmineralização óssea com hemorragias subperiósteas, despigmentação do cabelo e da pele e formação de elastina defeituosa. Se não for tratada pode levar a insuficiência na eritropoeses, degeneração cerebral e cerebelar e finalmente d morte.

- Iodo - A única função conhecida do iodo é participar dos hormônios tireóideos. E encontrado em alimentos do mar, como moluscos, lagostas, sardinhas e outros peixes. Os peixes de água salgada contêm 300 a 3000 nc/ kg de peso; os peixes de água doce contêm de 20 a $40 \mathrm{ng} / \mathrm{kg}$ e são fontes potentes desse mineral. $\mathrm{O}$ conteúdo de iodo no leite de vaca e nos ovos é determinado pelos iodetos disponíveis na dieta animal; os iodetos nos vegetais variam com a concentraçăo do solo onde foram cultivados.

A falta de ingestão de iodo está associada com o aumento do bócio simples ou endêmico, que é um alargamento da glândula tireóide. A falta de iodo durante a gestaçăo pode resultar no cretinismo. 
- Flúor - é considerado essencial pelo seu efeito benéfico no esmalte dos dentes, conferindo uma resistência máxima à cárie dentária.

As principais fontes dietéticas de flúor são a água potável e os alimentos industrializados preparados com água fluoretada.

- Cromo - O cromo é essencial para a manutenção do metabolismo dos carboidratos e lipídios e parece estar envolvido na funçăo da insulina. A determinação precisa do cromo nos alimentos é difícil. $\mathrm{O}$ cromo biologicamente disponível e o inorgânico não podem ser distinguidos. Levedo de cerveja, ostras, figado e batatas têm uma alta dose de cromo; alimentos marinhos, grãos integrais, queijos, galinha, carne, centeio, frutas frescas e vegetais têm uma concentração intermediária.

A deficiência de cromo conduz a alterações no metabolismo dos carboidratos como a intolerância à glicose, glicosúria, hiperglicemia acelerada, elevação dos níveis de insulina sérica e diminuição da ligação insulínica. Podem aparecer também crescimento desordenado, neuropatia periférica e equilibrio nitrogenado negativo.

- Cobalto - A única função biológica conhecida do cobalto é como componente da vitamina B12 (cobalamina). Essa vitamina é essencial para a maturação das hemácias e funcionamento normal de todas as outras células.

A deficiência de cobalto só ocorre quando há deficiência de vitamina B12 e a falta desta vitamina causa a anemia macrocitica. 
- Selênio - Os efeitos oxidantes do selênio e vitamina E podem reforçar a idéia de atuação mútua no efeito terapêutico. Selênio age com tocoferol para proteger a célula e as organelas da membrana contra danos oxidativos, facilitar a união entre oxigênio e hidrogênio no final da cadeia metabólica, transferir íons através da membrana celular e ajudar na síntese das imunoglobulinas e ubiquinonas.

Os alimentos mais ricos em selênio são a castanha do Pará, alimentos marinhos, rim, figado, carne e aves.

Duas doenças humanas ocorrem em áreas onde o solo é pobre em selênio:

A doença de Keshan - Caracterizada por uma miocardiopatia que afeta principalmente as crianças e foi observada pela primeira vez na província de Keshan, na China.

A doença de Kashin-Beck - Acomete adolescentes e pré-adolescentes, envolvendo uma rigidez simétrica, inchaço, dores nas juntas interfalangeanas dos dedos seguida de uma osteoartrite nos cotovelos, joelhos e ancas.

A falta de ingestão de selênio pode estar relacionada com a mortalidade pelo câncer. 


\section{Vitaminas:}

Vitaminas são compostos orgânicos essenciais para reações metabólicas específicas que não podem ser sintetizadas pelas células dos tecidos humanos, a partir de simples metabólitos. Muitas agem como coenzimas ou como partes de enzimas responsáveis por promoverem reações químicas essenciais.

As vitaminas são usualmente classificadas em dois grupos, com base na sua solubilidade:

\section{Vitaminas Lipossolúveis}

Cada uma das vitaminas lipossolúveis A, D, E e K tem um papel fisiológico separado e distinto.

- Vitamina A - Desempenha papel essencial na visão, crescimento e desenvolvimento ósseo, no desenvolvimento e manutenção do tecido epitelial, no processo imunitário e reprodução normal.

A pré-vitamina A é encontrada apenas nos alimentos de origem animal, seja nas áreas de depósito, como figado, ou associada com a gordura do leite e ovos. O caroteno é encontrado nos vegetais folhosos verde-escuro, nos vegetais amarelo-alaranjados e frutas; Cores mais escuras são associadas com níveis mais elevados de pró-vitamina.

A deficiência da vitamina A pode causar alterações na pele, cegueira noturna e úlceras corneal. Em casos de deficiência extrema, as membranas mucosas dos tratos respiratório, gastrointestinal e geriurinário são afetadas. 
- Vitamina D - Promove a absorção intestinal ativa do cálcio através da estimulação da síntese de proteína de ligação do cálcio na borda em escova da mucosa intestinal.

É encontrada em quantidades muito variáveis na manteiga, nata, gema de ovo e figado. A melhor fonte alimentar é o óleo de fígado de peixe.

A deficiência de vitamina $D$ se manifesta como raquitismo nas crianças e osteomalacia nos adultos. A falta de vitamina D pode também contribuir para o desenvolvimento da osteoporose.

- Vitamina E - Age nos alimentos para evitar a peroxidação de ácidos gordurosos poliinsaturados. Ao nível do intestino, ela acentua a atividade da vitamina A prevenindo sua oxidação no trato intestinal.

Ao nível celular, a vitamina $\mathrm{E}$ parece proteger as membranas celulares e subcelulares da deteriorização por catalisação de radicais livres que contêm oxigênio.

A vitamina E está amplamente disponível em alimentos embutidos. Óleos de sementes, particularmente o óleo de germe de trigo, são as mais ricas fontes, embora quantidade menores também ocorram nas frutas, vegetais e gorduras animais.

Devido à ampla disponibilidade dietética de vitamina $\mathrm{E}$, as deficiências são raras, porém pode estar associada com sintomas de neuropatia periférica. 
- Vitamina $\mathbf{K}$ - A vitamina $\mathrm{K}$ funciona no figado como um cofator essencial para a carboxilase, possuindo um papel de coagulação sangüínea.

É encontrada em grandes quantidades nos vegetais verdes folhosos, principalmente brócolis, repolho, nabo e alface. Outros vegetais, frutas, cereais, laticínios, ovos e carne contêm menores quantidades.

A deficiência de vitamina $\mathrm{K}$ pode ocasionar a Doença Hemorrágica do recémnascido, manifestada por sangramento anormal.

\section{Vitaminas Hidrossolúveis:}

A maioria das vitaminas hidrossolúveis é componente de sistemas enzimáticos essenciais. Muitas estão envolvidas na manutenção de reações do metabolismo energético. Essas vitaminas não estão normalmente armazenadas no organismo em quantidades apreciáveis e são normalmente excretadas em pequenas quantidades na urina; portanto, um suprimento diário é desejável para evitar depleção e interrupção das funçð̃es fisiológicas normais.

- Vitamina B1 (Tiamina) - Tem papel essencial na transformação energética e condução de membranas e nervos e, também, na síntese de pentoses e a forma de coenzima reduzida na niacina.

As fontes mais importantes de tiamina são a carne de porco magra e germe de trigo. Os órgãos, carnes magras e de aves domésticas, gema de ovo, peixe, legumes, grãos integrais e pães enriquecidos e cereais também são fontes excelentes. 
Deficiência de tiamina é frequentemente associada com alcoolismo, sendo a terceira causa mais comum de demência nos EUA. Sinais clínicos da deficiência de tiamina envolvem inicialmente os sistemas nervoso e cardiovascular, eventualmente expressados através da doença beri-beri, nas formas "seca" e do tipo "úmido".

- Vitamina B2 (Riboflavina) - Funciona primariamente como um componente de coenzimas flavina adenina dinucleotídio (FAD) e flavina adenina mononucleotídio (FMN). FAD, a forma predominante, é um componente essencial de produção de energia através de cadeia respiratória. As melhores fontes diárias são o leite, queijos cheddar e cottage. Vísceras contêm quantidades apreciáveis e carnes magras, ovos e vegetais verdes folhosos são fontes importantes.

Os sintomas precoces da deficiência da riboflavina incluem fotofobia, lacrimação, queimação e coceira dos olhos, perda de acuidade visual, inflamação e rachadura dos lábios, boca e língua e ariboflavinose.

- Niacina - Niacina é o termo genérico para a nicotinamida e ácido nicotímico, que tem como função ser componente das coenzimas NAD e NADP. Essas coenzimas são essenciais nas reações de oxidação-redução, envolvidas na liberação de energia dos carboidratos, gorduras e proteinas, onde servem como receptores capazes de aceitar e libertar átomos de hidrogênio à medida que eles são removidos pelas enzimas desidrogenases. NAD é também usado na síntese do glicogênio. 
Deficiência de niacina nos estágios iniciais incluem fraqueza muscular, anorexia, indigestão e erupçőes cutâneas. Deficiência grave leva à pelagra, que se caracteriza por dermatite, demência e diarréia.

- Vitamina B6 - Existe em três formas: Fosfato Piridoxal (PLP), fosfato piridoxamina (PMP) e piridoxina. As melhores fontes são levedo, germe de trigo, came de porco, vísceras, cereais integrais, legumes, batatas, bananas e aveia.

A deficiência da vitamina B6 leva os pacientes a desenvolverem neurite periférica e muitos dos sintomas de deficiência da piridoxina.

- Folato (Ácido Fólico, folacina ou pteroilmonoglutamato) - Folacina e folato são uma classe genérica que inclui u grupo de compostos químicos e nutricionalmente similares ao ácido fólico. Eles funcionam como coenzimas no transporte de fragmentos de carbono no metabolismo dos aminoácidos e síntese de ácidos nucleicos.

As melhores fontes são fígado, feijðes roxos, fava e vegetais folhosos verde= escuros frescos, especialmente espinafre, aspargo e brócolis. Fontes boas são carne magra, batatas, pão de trigo integral e feijðes secos.

A principal consequência metabólica de deficiência de ácido fólico é a alteração do metabolismo do DNA. Isto resulta em alterações na morfologia nuclear, especialmente naquelas células com as mais rápidas taxas de multiplicação - hemácias, leucócitos, células epiteliais do estômago, intestino, vagina e cérvix uterina. 
- Vitamina B12 - É essencial para o funcionamento normal do metabolismo da célula, principalmente as do trato gastrointestinal, medula óssea e tecido nervoso.

As fontes mais ricas são figado, rim, leite, ovos, peixe, queijo e carnes.

A deficiência da cobalamina diminui a síntese de DNA resultando em proliferação defeituosa de células que se dividem rapidamente e se manifestam por anemia megaloblástica, glossite e hipospermia. 
ANEXO 2 
São Paulo,

Prezado Sr.

Este instrumento de coleta de dados faz parte do trabalho de dissertaçăo de mestrado desenvolvido no âmbito do curso interunidades PRONUT, que engloba as faculdades de Saúde Pública, Farmácia e Administraçāo, Economia e Contabilidade da Universidade de São Paulo.

O objeto de estudo está sendo os Programas de Qualidade de Vida ganhadores do Prêmio Nacional de QVT, promovido pela Associação Brasileira de Qualidade de Vida - ABQV. Tem-se como objetivo apurar todas as ações desenvolvidas dentro dos programas de Qualidade de Vida no Trabalho, com ênfase nos programas de alimentaçăo e nutrição, dada a importância relevante desse tema na saúde do trabalhador.

Solicitamos que o questionário seja devolvido até $\quad / \quad /$ e para esclarecimentos de eventuais dúvidas, contatar 11- ou , com Eliete ou através do e-mail ebernal@terra.com.br

Os dados apurados serão tratados respeitando-se a confídencialidade das informações e os resultados serão disponibilizados a todos os participantes.

Desde já, agradecemos a sua valiosa contribuição.

Eliete Bernal A rellano Mestranda
Antonio Carlos Campino

Orientador
Ana Cristina Limongi

Co-orientadora 
ANEXO 3 


\section{QUESTIONÁRIO PARA O TRABALHO DE DISSERTAÇÃO DE} MESTRADO -

“ QUALIDADE DE VIDA NO TRABALHO: COMO A NUTRIÇÃO ESTÁ INSERIDA NOS PROGRAMAS DE QVT"

\section{Identificaçăo da Empresa}

1.1 - Empresa:

1.2 - Responsável pelas informações:

1.3 - Cargo:

1.4 - Número de Empregados:

1.5 - Número de Funcionários de Recursos Humanos:

1.6 - Endereço:

1.7 - Telefone:

1.8 - E-mail:

2. Sobre a história da empresa:

2.1 - Ano de criação

2.2 - Principal Atividade

2.3 - Principal Missão

2.4 - Composição do capital da empresa: \% Nacional / $\%$ Internacional

2.5 - Origem da Empresa

\section{Sobre o Programa de Qualidade de Vida no Trabalho:}

3.1 - Quando foi implantado

3.2 - No caso de empresas multinacionais, o Programa de QVT foi desenvolvido localmente ou seguiu os padrões da Matriz 
3.3 - Dentro do organograma da empresa, como está inserido.

3.4 - Público-alvo (funcionários, familiares, comunidade)

\section{4 - Sobre a Alimentaça e Nutriça:}

4.1 - É contemplada no Programa.
( ) Sim
( ) Não

4.2 - Caso positivo, qual o ano de Implantação do programa?

4.3 - Quais as ações que já foram desenvolvidas?

\begin{tabular}{|c|c|c|c|c|}
\hline \multirow{2}{*}{ Nome da Ação } & \multirow{2}{*}{ Conteúdo } & \multirow{2}{*}{ Resultados } & \multicolumn{2}{|c|}{$\begin{array}{c}\text { Está em } \\
\text { vigência? }\end{array}$} \\
\hline & & & Sim & Não \\
\hline & & & & \\
\hline & & & & \\
\hline
\end{tabular}

4.5 - Que instrumentos de avaliação/ indicadores foram utilizados?

4.6 - Houve acompanhamento médico/ avaliação antropométrica? Caso positivo, quais as variáveis levantadas e resultados obtidos.

4.7-Outras informações relevantes. 


\section{5 - Sobre outras Ações de Programa:}

5.1 - Quais outras açð̃es estão sendo contempladas no programa:

\begin{tabular}{|c|c|c|c|c|c|}
\hline \multirow[t]{2}{*}{ Nome da Ação } & \multirow{2}{*}{$\begin{array}{c}\text { Ano de } \\
\text { implanta } \\
\text { ção }\end{array}$} & \multirow[t]{2}{*}{ Conteúdo } & \multirow{2}{*}{ Resultados } & \multicolumn{2}{|c|}{$\begin{array}{l}\text { Está em } \\
\text { vigência? }\end{array}$} \\
\hline & & & & Sim & Não \\
\hline & & & & & \\
\hline & & & & & \\
\hline & & & & & \\
\hline & & & & & \\
\hline
\end{tabular}

5.2 - Quais os instrumentos de avaliação utilizados?

5.3 - O Programa de QVT foi avaliado pelos funcionários?
( ) Sim
( ) Não

5.4 - Caso positivo, qual a Visão dos empregados sobre o Programa. de QVT?

5.5 - Qual a Visão da Direção sobre o Programa de QVT?

5.6 - Há algum indicador de mudança organizacional, como consequência da implantação do Programa de QVT?

5.7 - Qual o índice de turn-over e absenteísmo da empresa dos três anos anteriores à implantação do Programa de QVT e dos anos seguintes?

\begin{tabular}{|l|l|l|}
\hline Ano & Índice de turn-over & Índice Absenteismo \\
\hline & & \\
\hline
\end{tabular}

5.7 - Outras informações relevantes. 